\title{
Rastislava Stoličná-Mikolajová
}



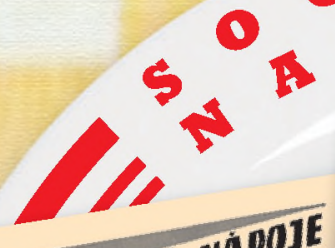

C I I I

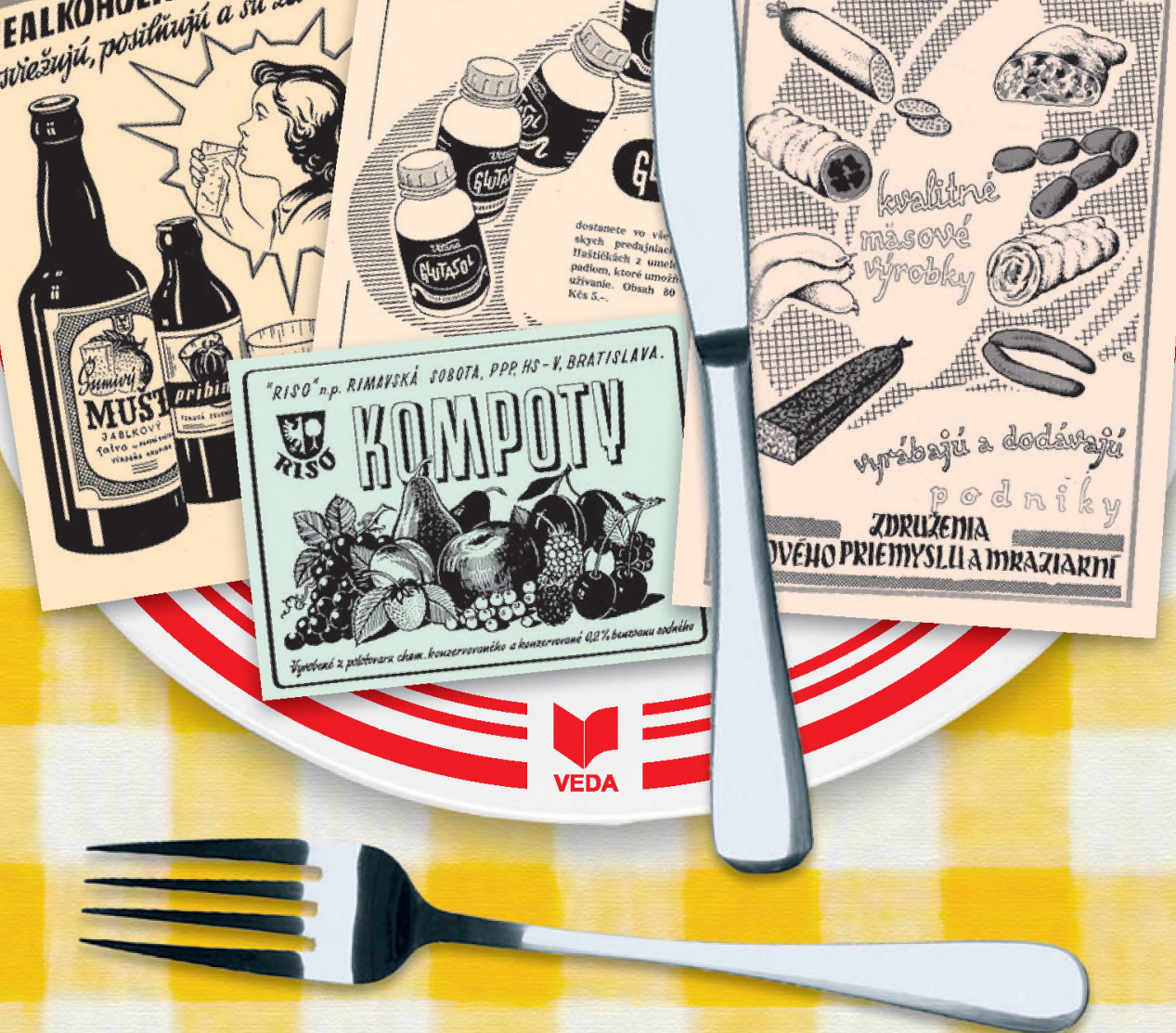



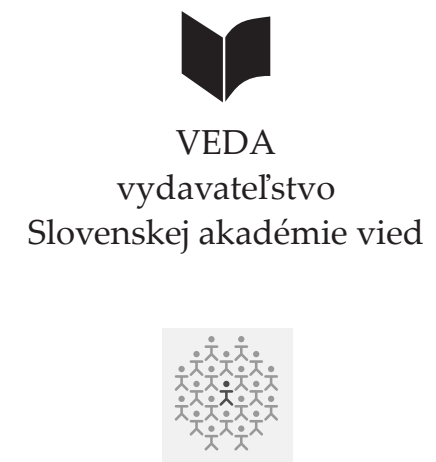

Ústav etnológie

Slovenskej akadémie vied 


\section{SLOVENSKÁ AKADÉMIA VIED ÚSTAV ETNOLÓGIE}

Recenzenti:

prof. dr. hab. Halina Rusek

doc. PhDr. Kornélia Jakubíková, CSc. 


\section{RASTISLAVA STOLIČNÁ-MIKOLAJOVÁ}

\section{Socializmus na tanieri}

Možnosti a praktiky stravovania obyvatel'ov Slovenska v rokoch 1948 - 1989

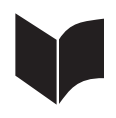

VEDA

vydavatel'stvo Slovenskej akadémie vied Bratislava 2015 
Kniha bola spracovaná v rámci Vedeckej grantovej agentúry Ministerstva školstva, vedy, výskumu a športu SR a Slovenskej akadémie vied ako projekt č. 2/0001/13 Stravovacie modely obyvatel'stva Slovenska v období socializmu.

\author{
Ilustrácie: \\ reklama na potraviny $\mathrm{v}$ časopise \\ Výživa a zdravie (1956 - 1975)
}

(c) prof. PhDr. Rastislava Stoličná-Mikolajová, DrSc.,

Ústav etnológie SAV v Bratislave, 2015

(C) VEDA, vydavatel'stvo SAV, 2015

ISBN 978-80-224-1467-8 


\section{OBSAH}

Úvod

Výživová politika prvej etapy budovania socializmu

na Slovensku

Nová vedecká koncepcia výživy ............................................... 18

Racionalizácia výživy socialistického človeka a nové potraviny 30

Výsledky dietologického výskumu ................................................ 64

Výsledky etnografického výskumu ........................................... 79

Predaj potravín ........................................................................................ 100

Alternatívne zdroje stravy ............................................................. 104

Socialistické formy verejného stravovania ................................... 112

Výsledky ankety o spôsobe stravovania v čase socializmu ......... 129

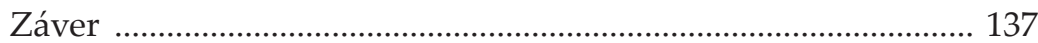

Použitá literatúra a pramene ........................................................... 142

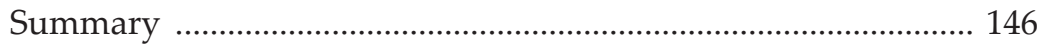





\section{ÚVOD}

Viaceré historické i etnologické práce o socializme ukazujú možnosti jeho vedeckého spracovania, a to aj napriek tomu, že toto obdobie našich dejín nebolo také priezračné, ako ho ukazujú mnohé dobové brožúry, oslavné spisy, knižky, články, filmové dokumenty či filmy, v ktorých bol obraz tejto doby zväčša idylický: robotníci budujú nové továrne, prekračujú normy, zlepšujú, družstevníci na traktoroch orú a na kombajnoch žnú, umelci tvoria, mládež sa usilovne učí, inteligencia sa k tomu pridáva, aj ked’ občas kolíše. To všetko vzrastá o príslušné percento z roka na rok, od plánu k plánu, od zjazdu komunistickej strany k d’alšiemu jej zjazdu... Ak sú nejaké t’ǎkosti, potom je to iba premáhanie dedičstva neblahej minulosti či intrigy zvonka. Naopak, tieto práce ukazujú reálny život l’udí v socializme, ktorý však nebol ani taký jednoduchý a prvoplánový, ako sa o to zasa snažia kritici tohto obdobia (Lipták: 2000, $288-289$ ).

Politický režim pod vedením Komunistickej strany Československa, nastolený v našej krajine v roku 1948, masívne ingeroval do celého komplexu funkcií a noriem spoločnosti. Komunistická ideológia, osobitne v prvej etape svojej existencie, ked' sa tvorili jej základy a podstata, popri primárnom cieli dobyt’ a upevnit’ si politickú moc mala aj víziu vytvorenia „nového“ socialistického človeka, ktorý by sa správal a žil zhodne s nastolenou politickou líniou. "Nový“ človek bola jedna z centrálnych figúr socialistickej epochy všeobecne. Jeho novost’ bola v ostrej opozícii s tradíciou, ale zároveň samotná idea nového modelu človečenstva vychádzala z európskej tradície modernity. Tento model propagoval nezávislost̉ indivídua od rodiny a zastupovanie rodinných zväzkov inými typmi kolektívnej spolunáležitosti. Zároveň odrážal symptómy všeobecných 
civilizačných zmien, ako boli vedecko-technický pokrok, urbanizácia, kolektivizácia, masová migrácia, emancipácia žien a všeobecná kultúrna emancipácia spoločnosti. Komunistická propaganda sa často odvolávala práve na tieto fenomény a prispôsobovala ju svojim ideologickým potrebám (Brzóstowicz-Klajn: 2004, 147). Charakteristickým znakom tohto režimu bolo, že sa snažil formovat' „nového“ človeka vplývaním na každú, aj na tú najintímnejšiu zložku jeho života. Jedným z ciel'ov špecificky nasmerovaných na Slovensko malo byt pretvorenie vrstvy „zaostalého“ vidieckeho obyvatel'stva na modernú uvedomelú robotnícku triedu (Búriková: 2006, 83). Výsledkom tohto procesu bol fakt, že väčšina každodenných situácií prestala mat' individuálny charakter a stala sa celospoločenskou otázkou. To sa dotýkalo problematiky bývania, odievania, vzdelávania, kultúry, náboženstva, športu a, samozrejme, aj stravovania. Preferoval sa kolektívny život, kolektívna zábava i rekreácia. (Piotrowski: 2005, 143).

Modernizácia socialistického štátu sa sústredila predovšetkým na rozvíjanie tažkého priemyslu a budovanie infraštruktúry. Dôsledkom znárodnenia výrobných prostriedkov bolo, že rol'níci a robotníci neprodukovali pre vlastnú spotrebu, ale predávali svoju pracovnú silu štátu za peniaze vo forme mzdy. Produkovali pre nich indiferentný tovar, aby si za plácu mohli kúpił’ od štátu produkty, ktoré naozaj chceli, potrebovali a ktoré vyrobili zasa iní robotníci. To, že výrobné prostriedky vlastnil štát, a nie l’udia, ktorí ich používali, posunulo ich vztah $\mathrm{k}$ materiálnej kultúre smerom k spotrebe. Od kolektivizácie pol'nohospodárstva a znárodnenia priemyslu bola väčšia čast’ materiálnych vecí objektom spotrebitel'ského, nie výrobného vztahu. Obdobie budovania socializmu tak dovŕšilo spotrebnú revolúciu na Slovensku. Tieto zmeny v spotrebe sa prezentovali ako úspešná modernizácia socialistickej spoločnosti (Búriková: 2006, 83). Úroveň spotreby - jej dostatku či nedostatku vytvárala v socializme aj vztłah obyvatel'stva $\mathrm{k}$ tomuto režimu. $\mathrm{Na}$ jednej strane nárast $\mathrm{v}$ spotrebe a zabezpečení základných potrieb občanov slúžil komunistickej strane na legitimizáciu jej moci, na 
druhej strane nedostatok určitých tovarov (predovšetkým základných potravín) sa odrážal v ich kritickom hodnotení socialistickej reality (Miller: 1995, 15 - 16).

V tejto práci sa pokúsim objasnit’ najvýraznejšie zmeny, ktoré nastali v oblasti koncepcie výživy obyvatel'stva a nových stravovacích modelov l'udí počas epochy budovania socializmu na Slovensku. Inšpiráciou mi bola práca Marion Nestle Food politics (2007), ktorá hovorí o tom, že štúdium výživy l’udí je vhodné na analyzovanie každej spoločenskej zmeny. Ked’že človek potrebuje jest’ v každej dobe, rôzne udalosti, procesy a zmeny v spoločnosti možno uchopit’ cez stravu a s ňou spojené praktiky a skúsenosti každodenného života. Jedlo tak mení abstraktné politické koncepty na osobné, vel'mi konkrétne reflexie týchto zmien.

$\mathrm{V}$ rámci takto nastaveného ciel'a bolo potrebné $\mathrm{v}$ prvom rade objasnit’ zásadné kontexty ingerencie štátnej komunistickej ideológie v oblasti stravovania. Tie sa jej dotýkali predovšetkým v prvom desatročí po politickom prevrate v roku 1948 a spôsobili zásadnú ruptúru v produkčno-zásobovatel’ských princípoch v oblasti stravovania obyvatel'stva Slovenska. Z novej politickej a hospodárskej situácie vyplynula aj nová koncepcia výživy socialistického človeka, ktorá sa inšpirovala najmä sovietskym modelom a aplikovala v stravovaní ludí v masovom meradle počas celého obdobia socializmu. Prejavilo sa to $\mathrm{v}$ postupných zmenách foriem stravovania $\mathrm{v}$ rodine aj mimo nej i v skladbe produkovaných a konzumovaných potravín. Úroveň stravovania obyvatel'stva v obdobiach socializmu na Slovensku dokladajú najmä dietologické a etnografické výskumné materiály, ktoré síce nie sú z časového, priestorového ani sociálneho hl'adiska homogénne, no prezentujú pomerne zretel'ný obraz stravy l'udí v sledovanom období. Podstatné boli aj informácie, ktoré poskytujú dobové časopisy o výžive, kde sa nachádzajú na jednej strane odborné pohl'ady na výživu, ale aj ideologické zdôvodnenia socialistickej koncepcie „výživy l’udu“. Tieto materiály tvoria v práci základný heuristický fundament, ktorý je doplnený reflexiami l’udí reagujúcich na toto obdobie cez prizmu jedla a stra- 
vovania. Na tieto hodnotenia bola použitá predovšetkým anketa a využité boli aj d’alšie relevantné knižné, časopisecké, internetové a mediálne zdroje.

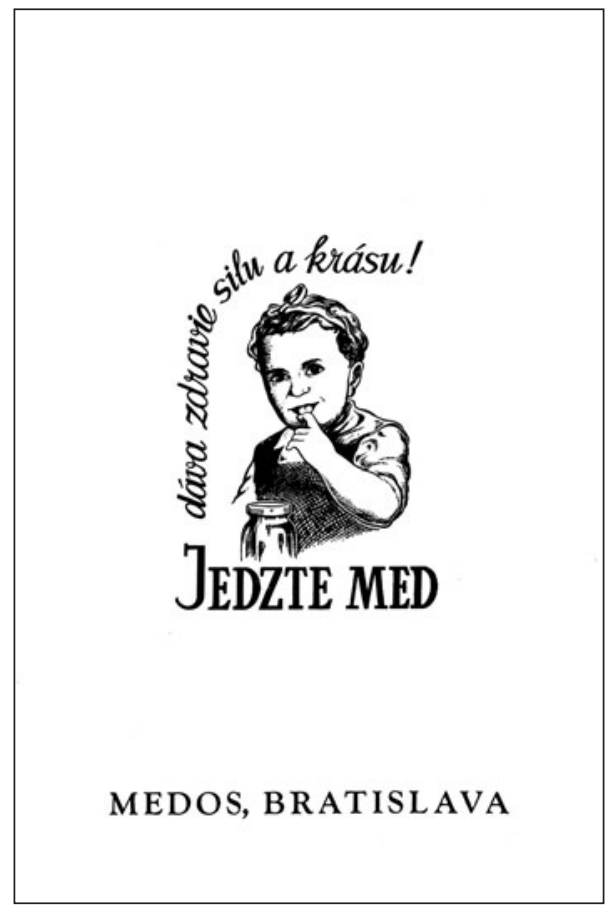




\section{VÝŽIVOVÁ POLITIKA \\ PRVEJ ETAPY BUDOVANIA SOCIALIZMU \\ NA SLOVENSKU}

Na konci druhej svetovej vojny vládlo v slovenskom ovzduší presvedčenie, že nebezpečenstvo pominulo, že sa konečne dá venovat' tomu, v čom vidí väčšina ludí zmysel i naplnenie svojho života. Vojna však zničila, najmä na východe Slovenska, vel’a obcí, mnohí ludia prišli o svoje domy a životné potreby.

Pol’nohospodárstvo bolo po skončení vojny značne vyčerpané. Oproti predvojnovému roku 1936 poklesli hektárové výnosy hlavných plodín pšenice, jačmeňa, zemiakov, stavy hovädzieho dobytka boli na Slovensku nižšie o $25 \%$ a ošípaných o 55 \%. Hrubá produkcia živočíšnej výroby predstavovala v roku 1945 iba 58 \% a produkcia rastlinnej výroby $63 \%$ v porovnaní s rokom 1936. Celkovo pol'nohospodárska výroba dosahovala $60 \%$ predvojnovej úrovne (Rychlík: 1993, 394 - 413).

V niektorých obciach bez pomoci rôznych zahraničných akcií, ako bola napríklad UNRA, by sa bolo dalo tažko vyhnút akútnemu hladu. Peniaze stratili cenu, obnovila sa naturálna výmena: šatstvo, nábytok a podobne za potraviny. Slovenské úrady síce obnovili a rozšírili prídelové hospodárstvo na základné potraviny a potreby, ale prídel vel'mi často nebol $\mathrm{k}$ dispozícii.

Zásobovanie na Slovensku bolo kombináciou viazaného prídelového hospodárstva a ",sivého“, mlčky trpeného pololegálneho zásobovania a čierneho trhu. Celková životná úroveň, presnejšie hmotná spotreba, v povojnových rokoch oproti vojnovým rokom na Slovensku citel'ne poklesla. Pár kilogramov múky, masti, niekol'ko metrov málo kvalitnej „drevenej“ látky či stovka cigariet predstavovali pre 
mnohých celé bohatstvo. Táto situácia odvádzala pozornost' l'udí od "vel'kej politiky“ k denným starostiam podl'a zásady "pomôž si sám“. Ťažké životné podmienky a katastrofálna neúroda v roku 1947 predížila tento stav na niekol'ko rokov (Lipták: 2000, 266 - 268).

Po vojne preto najmä rol'níci a živnostníci vítali revolučný tlak komunistov na rozdelenie majetku vel'koburžoázie, no ich úplné vítazstvo si nepriali, pretože s tým spájali koniec svojej vlastnej existencie, svojho postavenia, ktoré si chceli zlepšit', upevnit', avšak nie vymenit’ za najväčšie strašiaky vtedajšej Európy - sovietske kolchozy a vyvlastnenie majetku maloburžoázie. Znárodnenie klúčového priemyslu v októbri 1945 na Slovensku, kde dovtedy prevažoval priemysel l’ahký, potravinársky a malé podniky, zasiahlo vyše polovicu tovární. (Lipták: 2000, 271, 276).

Po politickej kríze v roku 1947 došlo vo februári nasledujúceho roka v Československu k politickému prevratu a moc v štáte uchopila komunistická strana. Február 1948 nebol len zavŕšením, ale aj počiatkom novej historickej epochy. Zavŕšením bol v tom zmysle, že mnohé, o čo predtým komunisti bojovali, bolo možné teraz rýchlo uskutočnit: sociálne zákonodarstvo, novú etapu znárodnenia, pozemkovú reformu. Vyše 90000 l'udí na Slovensku dostalo dekréty na pôdu zo skonfiškovaných majetkov nad 50 ha, pričom na každého rol’níka pripadlo priemerne 2,11 ha. Boli znárodnené všetky podniky nad 50 zamestnancov, v ktorých pracovalo 84 \% pracovníkov v priemysle. Znárodnený bol aj zahraničný obchod, vel'koobchod, kúpele. Klúčové pozície hospodárstva boli pevne v rukách štátu a štát v rukách robotníckej triedy.

Agrárny program KSČ do februára 1948 uplatňoval politiku získavania rolníkov v boji o politickú moc. V duchu koexistencie viacsektorovej ekonomiky (znárodnený, malovýrobný a kapitalistický sektor) rátala strana určitý čas s pretrvávajúcou existenciou malovýroby v polnohospodárstve. KSČ podporovala, podobne ako iné politické strany, družstevný princíp v tomto sektore, ktorý mal nadviazat’ na silné tradície českého a slovenského družstevníctva. Dňa 29. februára1948 predseda vlády Klement Gottwald i rezortný 
minister Július Ďuriš odmietli „reči o tom, že niekto chce u nás na dedine zavádzat' kolchozy".

Ďalšie smerovanie polnohospodárstva zásadným spôsobom ovplyvnila nová stratégia agrárnej politiky. V duchu Stalinovej teórie kolektivizácie vytýčilo vedenie KSČ hlavné smery a úlohy pol'nohospodárskej politiky. Bola to predovšetkým podpora združstevňovania na dedine, vybudovanie materiálno-technickej základne vo forme siete strojno-traktorových staníc (STS) a obmedzovanie a zatláčanie kapitalistických elementov na vidieku. Stalinská politika kolektivizácie vtlačila pečat’ a charakter štrukturálnej prestavbe polnnohospodárstva, poňatiu rol'níckych družstiev i prístupu k rol'níkom a vidieku vôbec. Bol prijatý zákon „,na ochranu republiky“, zaviedlo sa diferencované zásobovanie a diferencovaný rozpis dodávkových rol’níckych povinností. Zároveň pokračoval proces zjednocovania družstevníctva. Definitívne sa o ňom rozhodlo na decembrovom zasadaní Ústredného výboru Komunistickej strany Československa v roku 1948 schválením návrhu na zlúčenie všetkých existujúcich družstiev do jednotného rolníckeho družstva (JRD). Politika kolektivizácie bola úzko spätá s administratívno-direktívnym riadením hospodárstva a spoločnosti. Plánované pol’nohospodárstvo sa malo stat’ nástrojom, ktorý mal obmedzit či odstránit’ rozhodovanie kapitalistov a malovýrobcov, teda obmedzit' živelnost' a presadit’ autoritu a direktívnost’ plánu. Centralizované plánovanie, počnúc ministerstvom pol’nohospodárstva cez Štátny plánovací úrad a pol'nohospodárske referáty na krajských, okresných a miestnych úrovniach, bolo odtrhnuté od reality rol'níkov, dôsledkom čoho došlo k zväzovaniu ich iniciatívy a samostatnosti v rozhodovaní. Dňa 25. januára 1949 schválila vláda nový systém zabezpečenia výrobného a dodávkového plánu v pol'nohospodárstve, systém zmlúv o výrobe a dodávkach potravín medzi rolníkom a štátom (Hlavová: 2006, $131-143)$.

Po februári 1948 sa ukázalo, že politický systém budovaný u nás nebude ničím špecifickým, ale iba československým variantom systému, aký sa vyvinul v Sovietskom zväze v 30. rokoch 20. storočia. 
Tam sa už metódy rýchleho a úspešného prevzatia moci v štáte vyskúšali. Základnými a zdôrazňovanými otázkami sa stali predovšetkým kolektivizácia polnohospodárstva a téza o zostrovaní triedneho boja. Logickým dôsledkom tejto línie bola likvidácia stredných vrstiev, živnostníkov, súkromného obchodu ako „liahne“ a „zálohy“ kapitalizmu (Lipták: 2000, 292 - 297).

Na rozdiel od mestských stredných vrstiev, kde „skomunálnenie“ a združstevňovanie živností prebehlo pomerne hladko v priebehu dvoch až troch rokov, kolektivizácia na dedine sa pretiahla na desatročie. Niektoré družstvá a predovšetkým štátne majetky vznikli na Slovensku na skonfiškovaných pozemkoch vel'kostatkov zabratím pôdy, ktorá bola pôvodne vo vlastníctve obce, urbariátu alebo cirkvi, a počiatočné donucovacie stratégie, ktoré mali prinútit’ rol'níkov vzdat' sa svojho vlastníctva a vstúpit’ do družstva, mali povahu tzv. tretieho nevol'níctva. Popri nadšencoch, ktorí videli v družstvách cestu, ako sa vymanit’ z pomerov malovýroby, a ktorých existenciu i zásluhy by bolo zamlčovat chybné, vel'ká čast' rol'níkov prijala zospoločenštenie výroby ako nie príliš vítaný krok. Súčastou tlaku na vstup do družstiev boli neúmerne vysoké kontingenty, dodávkové povinnosti, ktoré museli rol'níci odovzdávat' štátu a neplnenie ktorých sa trestalo odobratím osiva, krmiva, dobytka, hospodárskych zariadení, ba aj väzením (Danglová: 2006, $56-57)$.

Aby mali komunisti prehl'ad o stave každého súkromného hospodárstva, vymenovali zo svojich radov revízorov. Pri mlátení obilia kontrolovali, či boli povinné dodávky splnené. Boli určení aj na súpis hospodárskych zvierat a podklady od nich sa použili na predpisovanie rozsahu dodávok kontingentu. Gazdom, ktorí boli v obci rozhodujúci a najprosperujúcejší, predpisovali dávky nad hranicou ich možností, aby ich mohli v prípade, že ich nesplnia, pokutovat’ alebo vymôct' od nich slub, že vstúpia do JRD. Rozmanitost' dodávkových povinností (okrem hovädzieho, bravčového mäsa a hydiny to boli vajcia, obilie, zemiaky, mlieko, maslo, kukurica) nútili rol’níkov vynakladat' vel'ké úsilie na ich zadováženie. Rol’níkovi, ktorý 
nestačil splnit’ kontingent predpísaných produktov, nedovolili domácu zakálačku.

Na toto obdobie nemajú dedinčania dobré spomienky, pretože predpisované kontingenty na potraviny boli také vysoké, že samotným rodinám nezostalo dost’ na vlastnú potrebu. Bežne sa rozšírilo porušovanie zákona. Robili sa tajné zakálačky, schovávalo sa obilie, zemiaky, víno a podobne (Kršek: 2010, 16 - 26; Stoličná: 2005, 29 - 30; Nováková: 2009,102 - 103).

Pri agitácii do JRD sa vysvetlovali iba výhody, práva, ale nijaké povinnosti: Scel'te pôdu, STS ju obrobí, sústred'te dobytok, kravy budú viac dojit', ošípané viac priberat', sliepky viac znášat'. V JRD vám bude lepšie, nebudete mat žiadne starosti. V̌̌etko za vás preberie družstvo. Aj to malo za následok, že čast’ družstiev sa čoskoro rozpadla. Preto ÚV KSČ vo februári 1951 prijalo nové, tvrdšie a násilnejšie metódy združstevňovania. Boli vydané smernice pre hospodársko-technické úpravy pozemkov, ktorými sa scel'ovali parcely pre JRD na úkor parciel súkromných rol'níkov. Náhradné pozemky mali často horšiu kvalitu a zvyčajne boli zastrčené v kútoch chotárov. Ak rol'níci takúto pôdu odmietli prijat', pridelili im ju dekrétom.

V období rokov 1949 - 1958 bolo len vel’mi málo prosperujúcich JRD. Táto realita sa zakrývala tvrdením, že brzdou úspechu sú „kulaci“. Aby štát nemal problémy s rol’níkmi, ktorí odmietli vstúpit’ do JRD, vyriešil to vládnym nariadením. Pôdu niekol'kých tisícok rol’níkov prikázal na základe uznesenia číslo 50/1955 zb. bez náhrady odovzdat' do používania miestneho JRD, čo bola čistá krádež na základe socialistického zákona. Avšak šikanovanie rol'níkov, ktorí ešte aj v roku 1958 hospodárili samostatne, pokračovalo d’alej (Kršek: 2010, 16 - 26).

Aj ked' komunistická propaganda neustále nadšene vyzdvihovala budovatel'ské úspechy znárodneného priemyslu a pol'nohospodárskych družstiev, hospodárska produkcia nestačila zásobovat’ obyvatel'stvo spotrebnými výrobkami ani potravinami na vol'nom trhu. V rokoch po skončení vojny bol zavedený prídelový lístkový systém potravín a jeho modifikovaný systém uplatnili komunis- 
ti od 1. januára 1950 do 31. mája 1953. Prídely potravín sa v ňom prísne limitovali a rozdel'ovali podla veku a povolania. Režimom privilegované vrstvy, napríklad baníci, hutníci, polícia, ale aj komunistické kádre, mali nárok na zvýšené dávky na tzv. viazanom trhu, kde sa nakupovalo na lístky. Zo systému boli vylúčené viaceré kategórie l'udí: vyšší úradníci, dôstojníci polície a armády z prvej ČSR, živnostníci, obchodníci. Tí mohli nakupovat' len na tzv. vol’nom trhu za niekol'konásobne vyššie ceny. Aj menší rol’níci, ktorí nesplnili povinné dodávky mäsa, mlieka a vajec, nedostali lístky na cukor a mydlo. O nič lepšie na tom neboli ani príslušníci neprosperujúcich JRD, ktorí nesplnili dodávky potravín do verejného sektora. Okrem toho vyhláška ministerstva vnútorného obchodu špecifikovala aj skupinu tzv. samozásobitel'ov, ktorí nemali nárok na potravinové lístky. Boli to držitelia pôdy nad 0,5 ha. Prídelový lístkový systém zanikol deň pred peňažnou výmenou (1.6. 1953), ked' si mohli ludia vymenit’ staré peniaze do výšky 300 Kčs v pomere $5: 1$ a vyššie čiastky a vklady v pomere 50 : 1 (Jirásek - Šůla: 1992, 16 - 20).

V denníku Rudé právo z 31. mája 1953 obhajoval tento krok vysoký funkcionár KSČ Viliam Široký takto: „Peňažná reforma a s ňou súvisiace opatrenia sú dôkazom strany a vlády o dobro pracujúcich a sú účinným prostriedkom d’alšieho zlepšovania materiálneho postavenia robotníckej triedy, družstevníkov, malých a stredných rol'níkov a pracujúcej inteligencie." Štatistická ročenka z roku 1958 však dokladá, že pred menovou reformou každý, kto mohol nakupovat’ na viazanom trhu, si mohol z priemernej výplaty kúpit ročne napríklad 656 kg chleba, no po reforme iba $328 \mathrm{~kg}$, alebo $131 \mathrm{~kg}$ ryže, no po reforme iba 17,5 kg. Po prepočítaní na euro stál kilogram hovädzieho zadného mäsa pred reformou 1,84 a po reforme 7,66 eura, $1 \mathrm{~kg}$ masla 3,07 a po reforme 17,25 eura. Týmito opatreniami v Československu výrazne zdraželi potraviny i d’alší spotrebný tovar.

Politické rozhodnutia realizované na Slovensku po februári 1948 mali zásadný vplyv na spoločensko-ekonomické zmeny. Po dlhých historických obdobiach, ked' bol hnutel'ný i nehnutel'ný majetok (na 
dedinách predovšetkým pôda a hospodárske zvieratá, v mestách zasa živnosti) v súkromných rukách a l’udia o ňom mohli slobodne rozhodovat', došlo v krátkom čase $\mathrm{k}$ jeho konfiškácii v prospech celej spoločnosti a predovšetkým jej revolučnej zložky - robotníckej triedy. Tento bezprecedentný krok KSČ, prirodzene, narazil na odpor, ktorý bol najvýraznejší na slovenských dedinách, kde sa rol'níci väčšinou bránili vstupu do vznikajúcich JRD. To spôsobovalo vel'ké problémy aj v zásobovaní trhu potravinovými komoditami, ked’že na jednej strane mnohé nové družstvá neboli schopné vyprodukovat' požadované množstvo potravín a na druhej strane súkromne hospodáriaci rol’níci dostali predpísané také vysoké dodávky potravín, ktoré nemohli splnit'.

Zároveň so socialistickou kolektivizáciou došlo aj k zoštátneniu potravinových podnikov: mlynov, pekární, mliekarní a pod. Vyústením tohto porevolučného chaosu v zásobovaní potravinami i d’alším spotrebným tovarom bolo zavedenie prídelového lístkového systému v rokoch 1950 - 1953 a následná peňažná reforma, ktorá väčšinu l'udí finančne poškodila.

V dôsledku týchto zásadných spoločensko-ekonomických faktorov nastala na Slovensku aj významná zmena v sociálnej štruktúre najmä dedinských komunít. Z mnohých pôvodne súkromných rol'níkov sa stali robotníci $\mathrm{v}$ továrňach, ktoré sa začali budovat’ v rámci socialistickej industrializácie Slovenska. Je len prirodzené, že pôvodný životný štýl týchto l’udí, vychádzajúci z rol’níckeho rurálneho prostredia, sa postupne menil na akúsi hybridnú formu so zázemím na vidieku, avšak s väzbami na robotnícku kultúru. To sa odrazilo aj v zmenách, ktoré postupne nastali v spôsoboch ich stravovania. 


\section{NOVÁ VEDECKÁ KONCEPCIA VÝŽIVY}

Zmena politického systému v našej krajine sa prejavila aj v jej začlenení do Rady vzájomnej hospodárskej pomoci (RVHP), ktorá mala zabezpečovat’ medzinárodnú del'bu práce a výmenný obchod v socialistických krajinách. V roku 1950 Československo prerušilo svoje členstvo v organizácii OSN pre výživu FAO a začalo si organizovat politiku dotýkajúcu sa výživy obyvatel'stva podl'a socialistických princípov. V roku 1951 vznikol Ústav pre výskum výživy l’udu v Prahe a v roku 1953 začal svoju činnost’ rovnaký ústav v Bratislave.

Smrt' J. V. Stalina a nástup N. S. Chruščova do vedenia v Sovietskom zväze v roku 1953 znamenali v celom sovietskom bloku obrat k väčšiemu záujmu o životnú úroveň obyvatel'stva. V oblasti výživy, podobne ako v d’alších oblastiach života, došlo k odbornej diskusii. Zdôrazňovala nielen vel'ký význam stravovania pre spoločnost', ale aj jeho dôsledky na zdravie človeka a sprostredkovane aj na jeho ekonomickú stránku ako prostriedku na zvýšenie produktivity práce. Zároveň sa v 50. rokov 20. storočia neustále akcentoval značný pokrok v kvalite stravy $\mathrm{v}$ porovnaní s medzivojnovým obdobím. Výživová koncepcia štátu a jej ciele v socialistickej spoločnosti sa definovali predovšetkým ako politická úloha.

V mnohých článkoch o výžive sa preto dávala do vypuklej ideologickej opozície výživa a stravovanie v kapitalistickom a v socialistickom hospodárskom systéme: „...V kapitalistickom zriadení sa výroba potravín riadi predovšetkým ziskom výrobcu, a len $v$ menšej miere skutočnou potrebou širokých más ludu. Chudobnejším vrstvám obyvatel'stva sa nedostáva dostatok potravín pre nedostatok finančných prostriedkov a kapitalizmus túto skutočnost’ ospravedlňuje rôznymi teóriami, napríklad teóriou Malthusovou o prel'udnení zeme, d’a- 
lej o jestvovaní javov, ktoré nie sú závislé od človeka, atd’. Hospodárske krízy pravidelne sa opakujúce v kapitalizme majú za následok rozvracanie hospodárskych pomerov, zbedačovanie pracujúceho l'udu a pokles kúpnej sily obyvatel'stva. To má za následok, že hoci na jednej strane sú prebytky zásob potravín, na druhej strane určité vrstoy chudobného a nezamestnaného obyvatel’stva žijú v stave podvýživy a hladu. (...) Aj na Slovensku $v$ čase kapitalizmu o stravovanie pracujúceho l’udu nebolo štátom postarané. (...) Robotníci na stavbách, v továrňach si prinášali niečo studenej suchej stravy so sebou na pracovisko, kde ho jedli narýchlo cez prestávku, obyčajne v prostredí nevhodnom, nehygienickom, často špinavom. Len $v$ málo továrňach bolo zavedené spoločné stravovanie, a aj to bolo postavené na zárobkovom princípe. Väčšina obyvatel'stva sa stravovala $v$ domácnostiach, ktoré vykazovalo vel'a nedostatkov a nevýhod. Stravu pripravovala žena, ktorá bola takto viazaná k jednotvárnej, neproduktívnej práci, čím sa ubijalo jej sebavedomie, túžba po rovnoprávnosti a tvorivej samostatne práci. Domáce stravovanie bolo drahé, nerentabilné a jeho najväčšou chybou bolo to, že sa nedostávalo v plnej miere pracujúcim mimo bydliska. O stravovanie detí wôbec nebolo postarané. Nebolo jasiel', družín mládeže a stravovanie v materských školách nebolo zavedené. Deti pracujúcich žien boli ponechané bez dozoru. (...) Stravovanie na internáte si mohli zaplatit’ len žiaci zo zámožnejších rodín. (...) Aj stravovanie v nemocniciach bolo rozdelené podl'a zámožnosti pacientov. (...) Dnes nastal radikálny obrat $v$ tomto nepriaznivom stave. Štát spejúci $k$ socializmu si uvedomil, že výživa l’udu a spoločné stravovanie, ako jeden z najdôležitejších vplyvov vonkajšieho prostredia, má zásadný význam pre zdravie, pracovnú schopnost' a odolnost' voči chorobám, d’alej pre vznik a rast mladej novej generácie. Preto prikročil k plánovanému a racionálnemu budovaniu spoločného stravovania pracujúcich aj detí a mládeže. V prvom rade sa prikročilo $k$ budovaniu siete závodných kuchýň, kde si pracujúci môže za lacný peniaz kúpit' teplé, biologicky a kaloricky vyhovujúce jedlo a zjest' ho vo vhodnom prostredí. Zavádzaním spoločného stravovania oslobodzuje sa žena od domácich prác, stavia sa do radu rovnoprávnych budovatel'ov, získava sebadôveru a prikladá ruku k dielu tam, kde najviac treba. Pracujúce ženy nemajú viac starosti o to, kto sa bude starat’ o najmenších počas pra- 
covnej doby, lebo im stojí $k$ dispozícii celý rad vzorne vystrojených jasiel' aj so stravovaním. Je postarané aj o stravovanie detí v materských školách a družinách mládeže. Spoločné stravovanie mládeže nie je viac problémom rodičov. Nemocničné stravovanie sa tiež zmenilo a bol vypracovaný nový diétny systém. (...) V socializme produkcia potravinových článkov je riadená výlučne potrebami ludí. Ukojit’ v najoyššej miere túto potrebu je hlavná zásada socialistickej ekonomiky. Produkcia potravín v socializme je plánovaná, a pretože v socializme nedochádza ku hospodárskym krízam, je postarané o rovnomernú dodávku, ba o zvyšovanie produkcie všetkých surovín v potrebnom množstve. Zvýšenie produkcie potravín je zabezpečené prechodom od malého neproduktívneho samostatného hospodárenia ku kolektívnemu hospodáreniu, vybavenému strojmi a vedeckými poznatkami agrotechniky..." (Bučko: 1956, 2 - 3).

Všeobecnou črtou dobových príspevkov o výžive bola viera, že nová socialistická spoločnost’ prinesie nový životný štýl i v oblasti stravovania. „...Socialistické zriadenie umožňuje úplné rešpektovanie biologických hl'adísk. Potraviny prestávajú byt’ predmetom zisku a stávajú sa prostriedkom $k$ tomu, aby nový socialistický človek bol zdravý a plne výkonný..." - takto znela čast' uznesenia pracovnej konferencie Spoločnosti pre racionálnu výživu v roku 1950. Zdôrazňoval to aj autor prvého úvodníka nového mesačníka Výživa a zdravie: „,...Stredobodom snaženia celej našej spoločnosti je všestranná starostlivost’ o človeka. Niet pochýb, že výživa obyvatel'stva, tak dôležitá pre zdravý vývoj žijúcich i budúcich generácií, musí stát v popredí tejto starostlivosti. Musí byt’ spoločnou snahou pracovníkov potravinárskeho priemyslu, vedecko-výskumných ústavov, pracovníkov zdravotníctva a členov Spoločnosti pre racionálnu výživu, aby sme nášmu l'udu zabezpečili takú výživu, ktorá zaručí jeho zdravie, pracovnú výkonnost' i spokojný občiansky život" (Marcelly: 1956, 2).

Pre značnú čast’ odborníkov, najmä pre lekárov, mikrobiológov, chemikov a fyzikov, to znamenalo, že budú môct' ovplyvnit' stravovanie más obyvatel'stva $\mathrm{v}$ miere, ktorá bola dovtedy nepredstavitel’ná. Dôvera v možnosti prírodných a technických vied v oblasti stravovania bola vel’mi silná a vízia vedcami riadenej spoločnosti 
predstavovala pre rad znalcov v oblasti výživy v 50. rokoch 20. storočia synonymum socializmu.

Optimistická nálada odborníkov na výživu a viera, že strava v socialistickom Československu sa stane stravou budúcnosti, ktorá bude príkladom pre výživu v ostatných štátoch sveta, narastali, pretože $\mathrm{v}$ porovnaní s predvojnovým obdobím narastala kvalitatívna úroveň potravín. Problematikou výživy sa začalo zaoberat niekol'ko stoviek odborníkov pôsobiacich v ústavoch výživy l'udu, d’alej lekári, ekonómia a sociológovia výživy, ktorí pôsobili v rámci potravinárskych a čiastočne pol’nohospodárskych výskumných ústavov, na ministerstvách výživy, zdravotníctva a vnútorného obchodu (Franc: 2003, 20 - 29).

V lete roku 1956 začal vychádzat’ na Slovensku mesačník Slovenskej spoločnosti pre racionálnu výživu, Výživa a zdravie. V jeho prvom úvodníku môžeme okrem iného čítat:" „Rozvojom národného hospodárstva v období I. pätročného plánu boli vytvorené predpoklady pre rýchly rast hmotnej a kultúrnej úrovne nášho obyvatel'stva. Jej najcitlivejším ukazovatel’om je stav v zásobovaní potravinami. Treba povedat', že dnes sme sa už vysporiadali s problémom zabezpečenia dostatku potravín. V roku 1953 definitívne sme skoncovali s prídelovým hospodárstvom a d’alšie opatrenia našej strany a vlády, najmä menová reforma, rozmach pol'nohospodárskej výroby, potravinárskeho priemyslu a celého národného hospodárstva, nám umožňujú stále bohatšie zásobovat’ našich obyvatel’ov. Do popredia našej pozornosti čoraz nástojčivejšie vstupuje otázka d’alšieho zoyšovania akosti potravín, ich nutričnej hodnoty a trvanlivosti, otázka zabezpečenia racionálnej výživy obyvatel’stva. V tomto smere hlavná úloha pripadá potravinárskemu priemyslu. Podl’a návrhu smerníc ÚV KSČ na vypracovanie II. pätročného plánu má rozvíjat' výrobu tak, aby zvyšovala podiel výrobkov živočíšneho pôvodu, rozširovat’ akostnejšie druhy výrobkov, zvyšovat' ich kvalitu, vzhl'ad balenia a zabezpečit' vysokú hygienu pri výrobe. (...) Vedecky je stanovené, čo, kol'ko a kedy má človek jest', aby si udržal zdravie a silu..." (Marcelly: 1956, 1). V tomto texte však prekvapujú niektoré vytýčené ciele, napríklad: „...Zvýšit podiel tukového pečiva na 90 \% z celkovej výroby, zvýšit podiel viacstupňového piva na 50 \% 
výroby, zlepšit’ akost’ údenárskych výrobkov, zvýšit’ spotrebu bravčového mäsa...", teda potravín a nápojov, ktoré sa len t’ažko dajú zaradit’ medzi racionalizačné opatrenia vo výžive.

Zhruba od polovice 50. rokov 20. storočia sa začala v Československu kampaň v zmysle zmien výživovej politiky, ktorá zdôrazňovala prínos nových technológií a potrebu celkového prebudovania stravovacích návykov obyvatel'stva. Súvisela s dobovými modernistickými predstavami spojenými s presadzovaním vedeckých poznatkov do každodenného života. Medzi symboly dokladajúce najmä význam technických a biologických vied pre ozdravenie výživy patrili predovšetkým rôzne opracované potraviny. Išlo o polotovary alebo rôzne spôsoby konzervácie potravín. V odborných i propagačných materiáloch sa neustále zdôrazňovalo, že nedôvera k takýmto

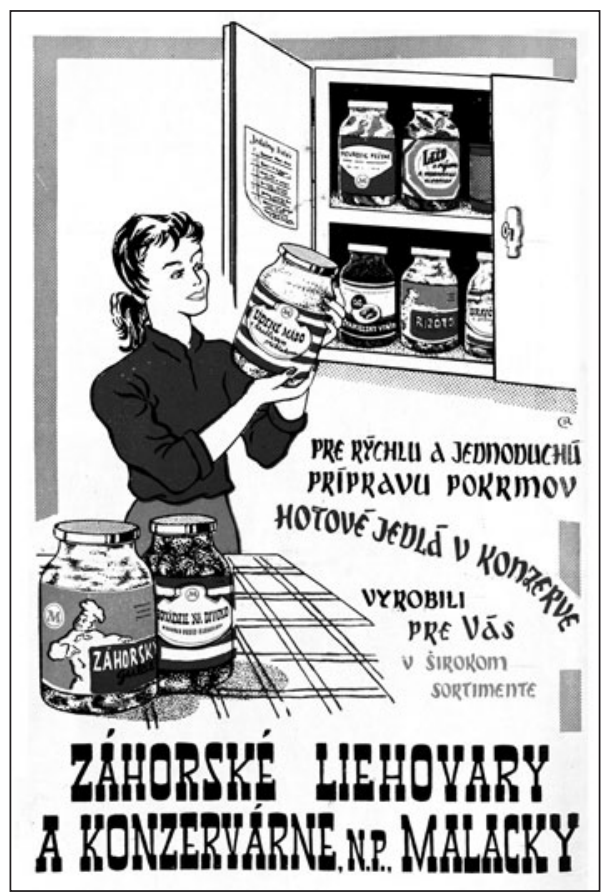


potravinám nemá reálne opodstatnenie, naopak, že takto spracované jedlá prinášajú výraznú úsporu času. Od rozvoja konzervačných metód sa očakávalo, že odstráni jeden z najzásadnejších problémov tradičnej kuchyne - sezónny pokles určitých ochranných látok, napríklad vitamínu $\mathrm{C}$ a A, bez toho, aby sa museli v zimnom a jarnom období dovážat väčšie množstvá južných plodov. Preto sa skúšali nové možnosti, napríklad konzervovanie pomocou rôznych druhov žiarenia, napríklad ionizačného či rádioaktívneho, alebo tzv. kryosilácia - sušenie pomocou chladu a tlaku. Mimoriadna pozornost’ sa venovala sušeniu mlieka a vajec. Kontroverzné boli aj pokusy s konzerváciou potravín, hlavne mäsa, pomocou antibiotika tetracyklínu. Výrazne sa začal rozvíjat’ mraziarenský priemysel, najmä preto, že konzervácia pomocou nízkych teplôt sa považovala z hl'adiska zachovania biologických hodnôt potravín za vel'mi výhodnú. Najdôležitejšiu úlohu tu zohrávalo presvedčenie, že mrazenie umožňovalo zachovanie vitamínu C, ktorého bol v niektorých obdobiach roka v strave kritický nedostatok. Propagácia sa však týkala priemyslovej konzervácie. Domáce spôsoby konzervovania potravín - solenie a údenie - sa zo zdravotníckeho hladiska skôr zavrhovalo ako prežitok minulých dôb (Franc: 2003, 131 - 142). Mraziarne ponúkali hotové jedlá, napríklad: hovädziu a držkovú polievku, plnenú papriku, slivkové knedle, bravčovú pečienku so zeleninou alebo cibul'kou, jaternicový "prejt“ alebo mrazenú zeleninu a ovocie.

Prudký rast výroby polotovarov súvisel aj s procesom „oslobodenia“ socialistickej ženy od domácich prác a zároveň s rozvojom spoločného stravovania, teda foriem výživy obyvatel’stva, ktoré podla dobových technokratických odborníkov na správnu výživu mali patrit’ socialistickej prítomnosti a neskôr aj komunistickej budúcnosti. Pritom sa rátalo s maximálnou centralizáciou výroby polotovarov a so vznikom polotovarového priemyslu ako samostatného odvetvia potravinárskeho priemyslu. Napriek všetkým proklamovaným výhodám nedopadla obluba polotovarov v počiatočných obdobiach tak, ako si to propagátori predstavovali. Dôvodom malo byt’ ignorovanie ekonomického významu času pri práci 


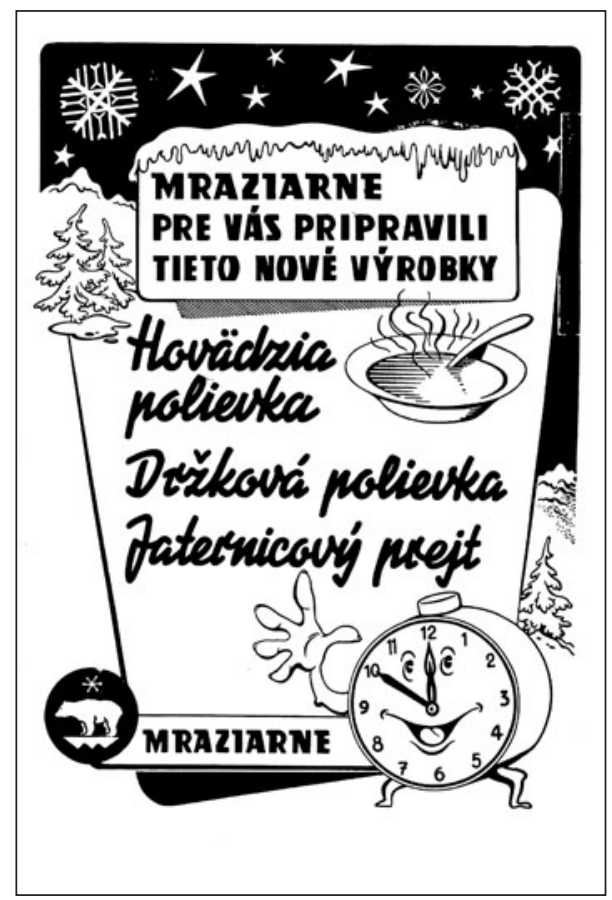

v domácnosti. Prekážkou väčšieho rozšírenia polotovarov na vidieku bol však skôr problém s ich distribúciou, cenou a prevažujúce tradičné stravovacie návyky (Hrubá: 1964, 121). Postupne však najmä vo väčších mestách vznikali špecializované predajne na tento tovar, dali sa v nich kúpit napríklad obal'ované rezne a syry, fašírky, plnené mäsové závitky a rolády, plnené papriky, žeml'ové knedle, mäsové krokety, ražniči, čevabčiči... V predajniach polotovarov sa predávali aj piškótové rolády, tortové korpusy, krémy, linecké a lístkové cesto. Zo sladkých jedál to boli ovocné knedle alebo parené buchty (Rašková: 1959, 156).

S technickým a technologickým rozvojom v oblasti výživy súvisel tiež plánovaný prechod k automatizovanej a kontinuálnej vý- 
robe potravín, ktorej pozitívnym výsledkom mala byt’ okrem iného aj hygiena výroby. Automatizácia výroby mala klúčový dosah na postupné stieranie špecifík potravinárskych výrobkov a vplyv na výslednú unifikovanú chut' spracovávaných produktov, čo však nebolo odborníkmi vítané. Priemyselná výroba sa stala terčom kritiky aj z hl'adiska poklesu biologických hodnôt, najmä vitamínu $\mathrm{C}$, takto pripravených potravín. Často sa kritizovalo pridávanie látok do potravín alebo padali dokonca obvinenia z „mŕtvych“ potravín, ktoré neobsahovali prirodzené, pre organizmus dôležité prvky. V socialistickom Československu sa však verejne nemohlo prejavit’ radikálne odmietnutie nekvalitných výrobkov potravinárskeho priemyslu. Naopak, v rámci procesu racionalizácie výživy obyvatel’stva sa mala pozícia potravinárskeho priemyslu nad’alej posilňovat'. Objektívne však treba povedat', že naša krajina patrila medzi tie štáty, ktoré

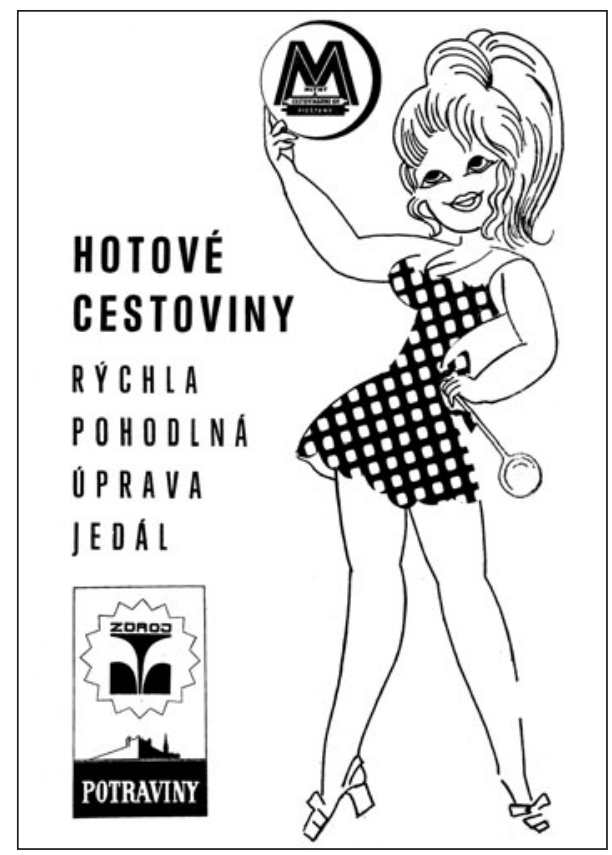


mali malý počet povolených prídavných látok do potravín (Franc: 2003, $144-145,153)$.

Osobitnou problematikou bola otázka vhodných obalov na potraviny. V roku 1958 autor článku v časopise Výživa a zdravie o tomto probléme napríklad konštatoval: „...Hoci v posledných rokoch u nás nastal značnejší pokrok v spotrebitel’skom balení potravinárskeho tovaru, predsa zostáva celý rad nevyriešených a nedoriešených otázok. 1. Predovšetkým je ešte celý rad druhov tovaru, ktorý nedostat’ $v$ balení vôbec, alebo len príležitostne. Zdíhavé plnenie vrecúšok a váženie v predajniach má za následok vel'mi pomalú obsluhu a vzniká strata času kupujúcich - spravidla pracujúcich žien. 2. Plnenie potravinárskeho tovaru do obalov v predajni má silné zdravotné a hygienické nedostatky. (...) 3. Vážnym nedostatkom je málo vkusné balenie. (...) Nedostatky našej obalovej techniky majú viac pričin. Je to úzky sortiment obalových materiálov, čo spôsobuje jednotvárnost' a uniformitu spotrebitel'ského balenia. Najmä papierový a lepenkový materiál, ktorý je najčastejší, nevyniká atraktívnostou. Tlač je jednotvárna, nedokonalá, farebne a výtvarne chudobná. Tvar často nevhodný, neúsporný. (...) Z hl’adiska hygieny je papier málo vhodný na balenie vlhkých, prípadne polotekutých druhov potravín, napr. majonézy, šalátov, bryndze, rybích výrobkov, ale aj mäsa. (...) Ďalšou príčinou nedostatkov v spotrebitel'skom balení je nedostačujúce využívanie novodobých materiálov, najmä umelých plastických látok a hliníkových fólií. (...) V našom štáte máme v oblasti spotrebitel’ského balenia čo doháňat. Doterajší stav balenia nezodpovedá vysokej úrovni nášho hospodárstva. Tento stav sa dá zmenit iba vysokou prácou technikov, výskumníkov, pracovníkov socialistického obchodu, hygienikov a výtvarníkov" (Schwaer: 1958, 10 - 11).

Napriek pomerne intenzívnej výskumnej činnosti v oblasti výživy obyvatel'stva bolo rozpačité aj zavádzanie nových technológií do potravinárstva. Zlá situácia bola v oblasti potravinárskych strojov. Potravinársky priemysel v 50. rokoch 20. storočia trpel predovšetkým na to, že v socialistickom hospodárstve sa preferoval tažký priemysel, a ten, čo fungoval, produkoval predovšetkým potraviny s vysokým podielom nežiaducich sacharidov. 
Okrem technologických problémov spôsobovalo komplikáciu aj to, že v porovnaní s vyspelejšími krajinami predstavoval nákup potravín pre obyvatel'stvo značnú zátaž. Výskum v spotrebe obyvatel'stva Slovenska v rokoch 1961 - 1974 ukázal, že na potraviny l'udia vynakladali približne tretinu príjmu. Podiel potravín vo výdavkovej štruktúre bol však sociálne diferencovaný. Najvyšší, viac ako 90 \%, bol u robotníkov a zamestnancov, zatial' čo u rol'níkov to bolo 77 \%, čo súviselo s existenciou tzv. záhumienkového alebo vlastného hospodárstva tejto sociálnej skupiny (Zatkalíková: 1977, 199 - 201). Ekonómovia sa snažili túto skutočnost’ vysvetl'ovat' tým, že na iné oblasti životných nákladov (bývanie, dane, zdravotníctvo, kultúra) sú výdavky v porovnaní s kapitalistickými krajinami nižšie. Vysoký

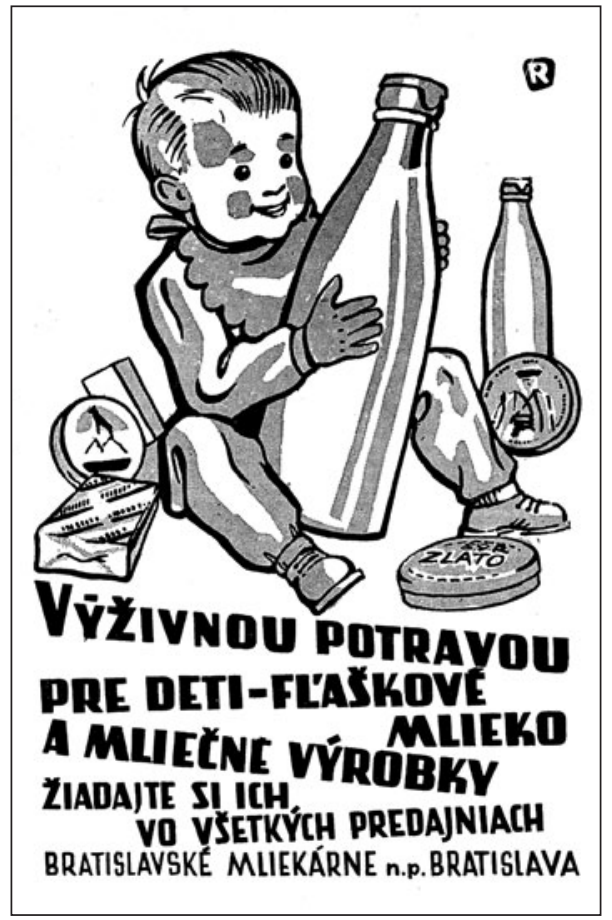


podiel výdavkov na potraviny však viedol k tomu, že väčšina domácností považovala racionálnu výživu, ktorá bola nadpriemerne drahá, za prepych. Občania kritizovali napríklad vysoké ceny mäsa, južného ovocia a masla. Najmä v polnohospodárstve, medzi pracovníkmi jednotných rol’níckych družstiev a štátnych majetkov, kde boli platy nízke, platilo „socialistické“ heslo „Kto nekradne, okráda svoju rodinu“. Bežná bola krádež vajec, mlieka alebo krmiva pre domácu ošípanú (Kršek: 2010, 32).

Odborníci na výživu sa preto snažili manipulovat’ verejnú mienku v prospech zlepšenia pomerov v stravovaní obyvatel'stva. Propagovali cenovo výhodné potraviny, aby sa ich spotreba zvýšila. Napríklad v časoch nedostatočného konzumu mlieka a mliečnych výrobkov alebo vajec poukazovali na nízku cenu tohto vysokého zdroja živočíšnych bielkovín. Jedným z leitmotívov propagácie racionálnej výživy okrem pestrosti bolo aj volanie po striedmosti, pretože sa enormne zvyšovala spotreba tukov a cukru.

Ďalšiu možnost’ manipulácie s cenami jedla ponúkal systém verejného stravovania, ktorého rozširovanie bolo jednou z prioritných snáh bojovníkov za správnu výživu. Verejné stravovanie sa malo stat’ hlavným zdrojom pozitívneho ovplyvňovania stravy širokých vrstiev obyvatel'stva (Franc: 2003, 30, 169 - 183). Táto forma stravovania sa zároveň používala ako argument emancipácie žien v socialistom zriadení. „...Súkromná kuchyňa spôsobuje miliónom žien najväčšiu námahu a stratu času, pričom zaviňuje vel’ké plytvanie a pripravuje ich o zdravie a dobrú vôl'u. (...) Zrušenie súkromnej kuchyne bude pre nespočetné ženy vykúpením, pretože to je taká zastaralá a prekonaná inštitúcia ako dielňa drobného remeselníka, obe znamenajú najväčšiu nehospodárnost', vel'ké plytvanie časom, energiou, kurivom, svetlom, potravinami... Tak ako v kuchyni, aj v ostatnej domácnosti dôjde $k$ revolúcii a ženám odpadnú nespočetné práce, ktoré dnes treba ešte vykonávat' (Bebel: $1956,486-490)$.

Koncepcia výživy obyvatel'stva na Slovensku bola po celé obdobie socializmu podriadená modernistickým predstavám o potrebe 
prenášat’ vedecké poznatky do každodennej praxe. Podla tejto koncepcie mal byt’ socialistický človek zdravý, a teda výkonný v práci, a preto bolo nevyhnutné, aby sa racionálne stravoval. Ak na počiatku obdobia socializmu išlo najmä o zabezpečenie dostatku potravín, postupne dochádzalo $\mathrm{k}$ akcentovaniu ich akosti. V dobových odborných diskusiách sa do popredia dostávala úloha potravinárskeho priemyslu zaviest' nové technológie do výroby potravín, a zároveň sa akcentovalo, že tieto nové produkty - polotovary, hotové konzervované a mrazené jedlá - majú byt čo najrýchlejšie zavedené aj do každodennej praxe. Tieto opatrenia boli zároveň politickým argumentom, ako socialistická spoločnost’ oslobodzuje ženu od práce v kuchyni. Socialistická žena už nemala byt' „ochrankyňou rodinného krbu“ ako stáročia predtým, ale plnohodnotnou pracovníčkou v národnom hospodárstve a nemala strácat’ čas prípravou stravy. K tomu jej malo pomôct' aj rozširovanie spoločného stravovania, ktoré malo zabezpečit’ výživu členov rodiny zdravou a kaloricky vyváženou stravou. 


\section{RACIONALIZÁCIA VÝŽIVY SOCIALISTICKÉHO ČLOVEKA A NOVÉ POTRAVINY}

Socialistická výživová politika sa vztłahovala najmä na osvetu a ovplyvňovanie stravovacích návykov obyvatel'stva. Realizovalo sa to formou odborných prednášok, najmä lekárov, pre verejnost’ alebo reláciami v rozhlase a neskôr aj v televízii. Vo vydávaných kuchárskych knižkách sa pravidelne jedna kapitola venovala problematike racionálneho stravovania. Nové potravinové produkty sa snažila spropagovat’ kreslená alebo fotografická reklama v časopisoch. Reklamné spoty na potraviny sa objavovali aj v televízii. Najmä pre vidiecke ženy sa organizovali kuchárske kurzy, v ktorých sa učili, ako správne a zdravo varit’ a piect'.

Odborníkom na výživu išlo v prvom rade o odbúravanie živočísnych nasýtených tukov v strave ako nežiaduceho zdravotného rizika. Hlavný útok sa preto viedol proti konzumácii bravčového tuku ako prežitku tradičnej dedinskej stravy. Dobové články sa snažili propagovat’ prednosti rastlinných olejov z repky, slnečnice, podzemnice olejnej či kukuričných kličkov, predávaných pod názvami PALMOL, HELIOL či MAJA. Ešte v 70. rokoch 20. storočia sa však stávalo, že na trhu nebol dostatok rastlinných olejov a obyvatel'stvo Slovenska ho chodilo kupovat’ do Mad’arska, ktoré muselo jeho predaj cudzincom regulovat'. Aj napriek vysokému obsahu cholesterolu sa podporovala spotreba masla ako súčasti žiaduceho objemu konzumácie mlieka a mliečnych výrobkov. Substitúcia masti a slaniny maslom bola považovaná za jeden z dokladov rastu životnej úrovne. Avšak aj čast’ masla musela byt’ do Československa dovážaná - v 50. rokoch 20. storočia z Dánska a v 60. rokoch zo ZSSR. Maslo 
sa predávalo na váhu. Najmä v 50. rokoch bola odborníkmi na výživu odporúčaná aj vyššia spotreba rybieho tuku, ktorým sa kŕmili predovšetkým deti. Medzi obyvatel'stvom nevzbudzovali nadšenie ani tzv. umelé tuky, aj ked' sa propagovali, pretože sa obohacovali vitamínmi A a D, ktorých bol v strave nedostatok. Predávali sa pod názvami POKRMOVÝ TUK, VISA, IVA, JUNO, HERA, SMETOL, SANA. Podl'a dobových výskumov obyvatel'stvo uprednostňovalo oleje a maslo a na Slovensku stále dominovala bravčová mast' (Jančík - Zeman: 1962, 202 - 209).

Boj za zníženie tukov v strave súvisel aj so snahou nahradit' v slovenskej kuchyni dominantné bravčové mäso inými druhmi mäsa. Odporúčala sa konzumácia ovčieho mäsa, ktorého cena bola preto v druhej polovici 50. rokov výrazne znížená, d’alej králičie-

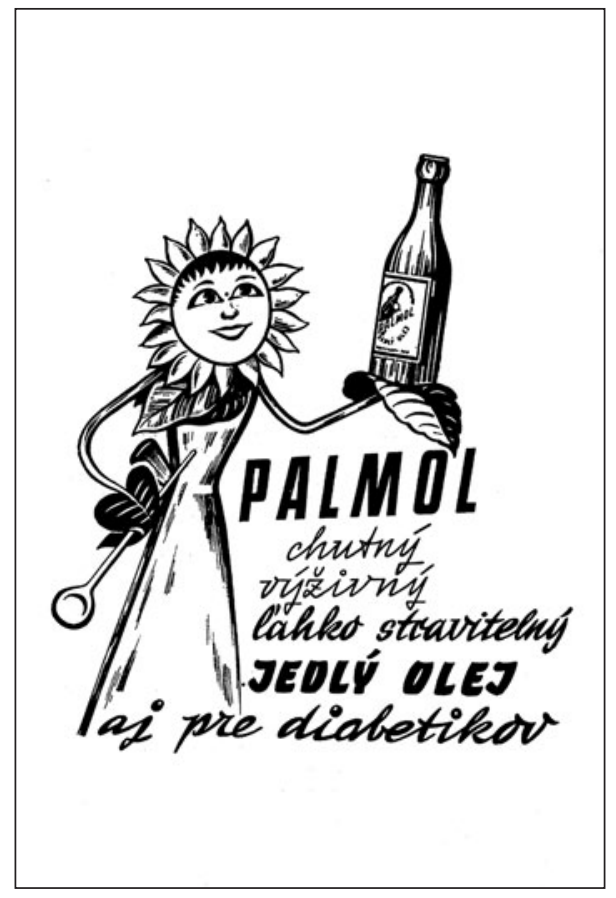






ho mäsa či zveriny. Dostatok kvalitného hovädzieho a tel'acieho mäsa nebola produkcia a distribúcia potravín schopná zabezpečit. Zvýšenie konzumácie hovädziny sa dokonca riešilo vládnym uznesením z roku 1965. Odporúčalo sa zvýšit aj spotrebu vnútorností, predovšetkým pečienky, ktoré patrili k lacnejším potravinám, ale na trhu ich bol aj tak neustály nedostatok. Pečienka na stole dlhé obdobia demonštrovala schopnost’ gazdinej zohnat' podpultový tovar. Rozsah konzumácie hydiny bol v Československu podla údajov z polovice 60. rokov 20. storočia na priemernej úrovni vyspelých krajín. Išlo predovšetkým o kurčatá, ktoré sa začali chovat’ vel'kokapacitným spôsobom (Zápotocký: 1964, 30). Predávali sa čerstvé alebo zmrazené. 
Spotreba mäsa sa plánovala (tak ako všetko ostatné) od aktuálneho zjazdu KSČ do nasledujúceho zjazdu. V čase politického súperenia medzi Východom a Západom (socializmom a kapitalizmom, Sovietskym zväzom a USA) sa úspechy na jednej či druhej strane merali i spotrebou mäsa. Sút’až, podporovaná tiež „vedecky“, pokračovala i neskôr - až do „nežnej“ revolúcie: „...Môj nebohý primár na internom oddelení nám rozprával príhodu, ako štát potreboval zvýšit’ spotrebu hovädzieho mäsa. Hlavný hygienik vtedajšej ČSSR tak vystúpil v televízii a rozplýval sa nad tým, aká je hovädzina zdravá. Jeho vystúpenie malo vel'ký úspech, a preto ho požiadali, aby to isté "číslo" predviedol o mesiac aj s bravčovinou, pretože tiež potrebovali zvýšit” jej spotrebu. Vočiach lekárov, ktorí ho poznali ako kamaráta, vtedy vel'mi klesol a stal sa terčom vtipov..." (Šišmiš: 2014, 18).

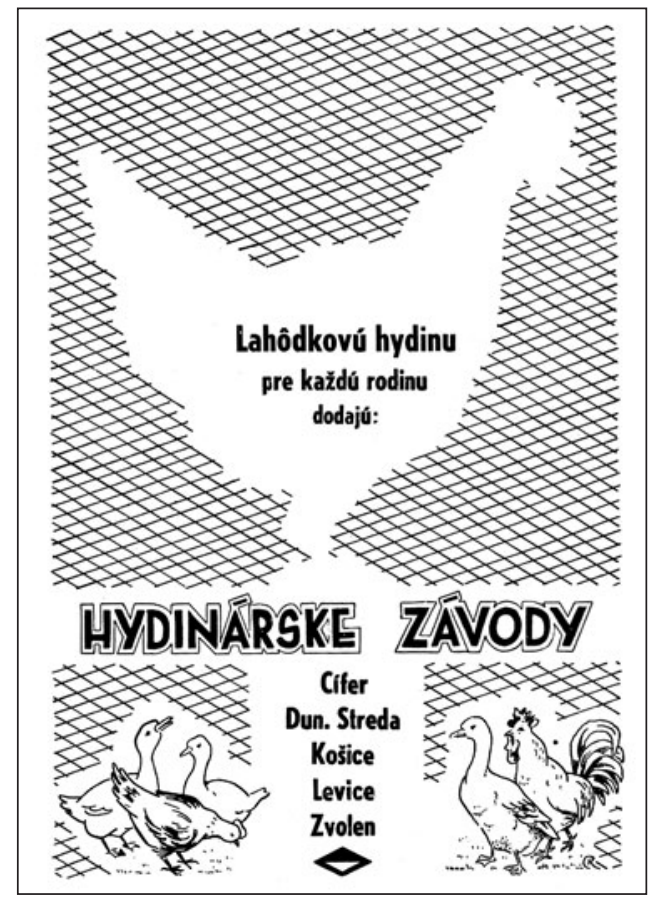


V ére socializmu vyzerali mäsiarstva všade rovnako: vykachličkované bielymi kachličkami, na stenách za predajným pultom na hákoch mäso a na pulte boli vyložené údeniny a konzervy. Vzadu mal mäsiar chladiaci pult. Nedostatok mäsa najmä v 50. a 60. rokoch 20. storočia nútil l'udí, aby sa tejto situácii prispôsobili. Korupcia a čierny obchod s mäsom sa začínali už na bitúnkoch, kde sa najkvalitnejšie mäso „strácalo“ v neprehl’adnej sieti známostí a protekcií. L'udia v mestách sa snažili mat’ „svojho“ mäsiara, ku ktorému sa chodilo mimo otváracích hodín alebo „odzadu“. Vtedy sa naskytla šanca kúpit’ aj kvalitné mäso, napríklad hovädziu sviečkovicu na bifteky alebo roštenku. Podobne to bolo aj s bravčovou pečienkou alebo hovädzím údeným jazykom. Takmer nedostupné bolo mäso telacie. Ked' prišiel nový tovar, väčšina l'udí vystávala na mäso rady už dlho pred otvorením mäsiarstva. Od 70. rokov 20. storočia sa

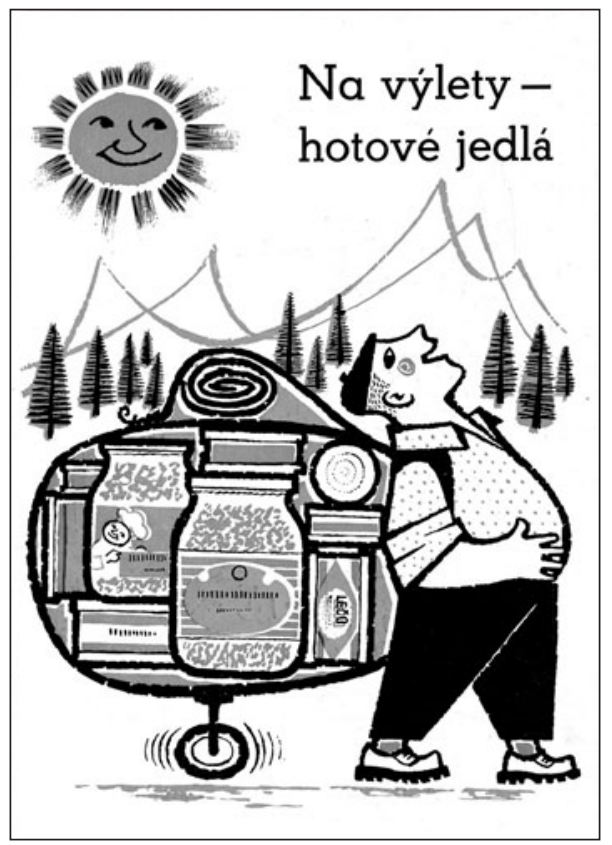


produkcia mäsa zvyšovala, ale pre bežných l’udí bol k dispozícii pomerne obmedzený sortiment, predovšetkým bravčové karé na rezne, krkovička alebo bôčik na pečenie. Špecializované mäsiarstva $\mathrm{s}$ ponukou mäsa zo zvierat, ktoré museli byt’ z rôznych dôvodov utratené, sa nazývali „Nútený výsek“. Cenový rozdiel medzi kvalitným a menej kvalitným mäsom nebol výrazný, aj tak však výdavky na mäso tvorili polovicu všetkých výdavkov za potraviny. Ako spomínajú pamätníci doby, ktorí pracovali v tomto odvetví, každý druhý zákazník bol pri predaji mäsa poškodený. Špecifikom socialistickej výroby bolo mäso nazývané REMA, ktoré sa pripravovalo zmiešaním bravčového a hovädzieho mäsa do plátkov, závitkov a pod., ktoré sa dodávali do zariadení verejného stravovania, ako boli školské a závodné jedálne.

Na dedinách si l’udia chovali hospodárske zvieratá - najmä králiky, hydinu a ošípané. Raz-dva razy do roka sa robila domáca zabíjačka, l’udia boli menej závislí od obchodu, aj preto bolo zásobovanie dedín mäsom často nedostatočné a spoliehalo sa práve na jeho domácu produkciu. Do socialistického Československa sa mäso aj dovážalo, napríklad hovädzina z Mongolska a Argentíny, ale aj vyvážalo, napríklad hovädzie jazyky do USA alebo tzv. „živé mäso" do Talianska. Mäso sa predávalo aj v konzervách, napríklad domáce bravčové vo vlastnej štave alebo dovážané, napríklad tzv. LANŠMÍT z Číny. Častou nátierkou chleba bola bravčová paštéta MÁJKA alebo PIONIER. Mäsové konzervy ludia v mestách kupovali a na dedinách aj robili ako istotu, keby si nemohli zadovážit iné mäso. V čase socializmu vyrábali konzervárne jedlá s mäsom, ako napríklad hovädzie na divoko, lečo s údeninou, sedliacky guláš, kapustu s kabanosom, hovädzie na hríbikoch, rizoto, záhorácky guláš, kura na paprike.

Konzumáciu údenín čast’ odborníkov síce zavrhovala, ale studené večere, ktoré sa skladali z údeniny a chleba alebo iného pečiva, boli medzi lud'mi oblúbené predovšetkým kvôli jednoduchej a rýchlej príprave a $\mathrm{v}$ neposlednom rade aj z finančných dôvodov, pretože boli relatívne lacné. To vyhovovalo najmä rodinám, kde sa 


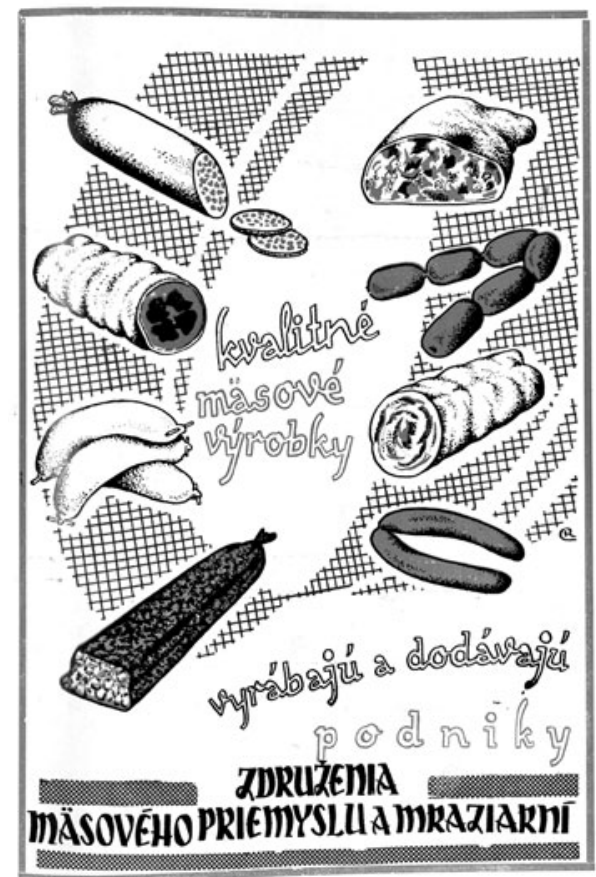

ženy zapojili do pracovného procesu a čas na varenie sa im výrazne skrátil. Na druhej strane sa argumentovalo zasa tým, že rozšírením spotreby údenín sa stierajú rozdiely medzi mestskou robotníckou stravou a stravou vidieckou, čo sa kvalifikovalo ako prejav rastu životnej úrovne (Hons - Úlehlová-Tilschová: 1961, 63 - 64). Treba však objektívne povedat', že údenárske výrobky v ére socializmu boli ovel'a chutnejšie ako dnes. Podl'a dobových svedectiev sa pri ich výrobe používalo menej chémie a vody, zato viac korenia, čím získali svoju charakteristickú chut. Mäkké salámy sa väčšinou nedali dobre lúpat', avšak šunková saláma patrila k najoblúbenejším údeninám. Často sa kupoval aj kabanos, točená saláma, špekáčiky, párky. L'udia vyhl'adávali najmä nedostatkové kvalitné mad’arské salámy a klobásy, na čo domáca produkcia postupne reagovala via- 
cerými typmi trvanlivejších údenín, ako boli: TURISTICKÁ, MALOKARPATSKÁ, ČINGOVSKÁ, LOVECKÁ SALÁMA, POLIČAN, GHOTAJ, VYSOČINA a pod. Najvyššiu kvalitu mala pražská šunka, ktorá sa však v konzervách vyvážala do USA a na domáci trh sa takmer nedostala. Aj iné druhy šunky bývali často nedostatkovou potravinou (www. ceskatelevize/porady/retro).

Popri kvalitnejšom mäse mala výrazne stúpnut’ aj spotreba mlieka a mliečnych výrobkov ako zdroja d’alších živočíšnych bielkovín. $\mathrm{V}$ tomto prípade sa však narážalo na pomerne vážne problémy. Spotreba mlieka vzhl'adom na nie príliš vysokú kvalitu, problémy s distribúciou a nehygienickým spôsobom predaja a vysokou chorobnostou dojníc v porovnaní s predvojnovým obdobím bola $\mathrm{v}$ priebehu 50. a v prvej polovine 60 . rokov 20. storočia hrozivo nízka. Dojičky kráv na JRD si bežne zlepšovali výkon tak, že prilievali

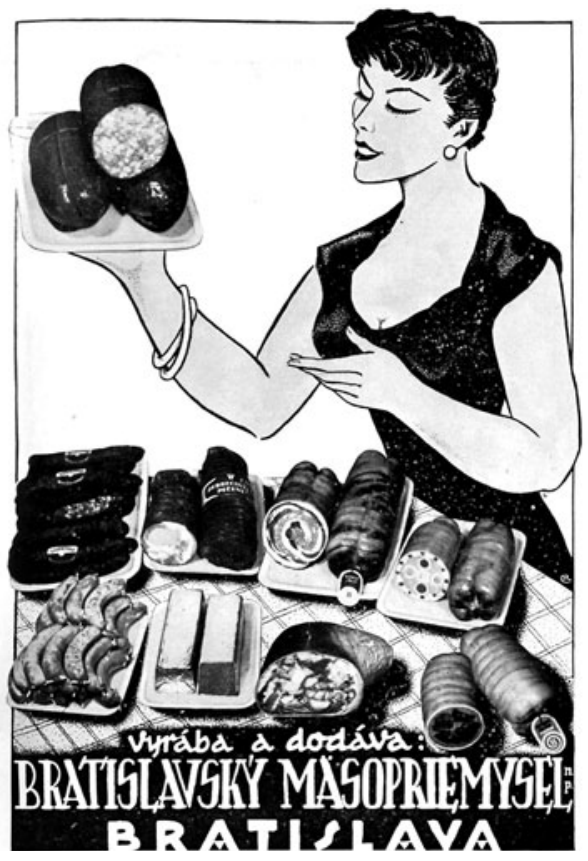




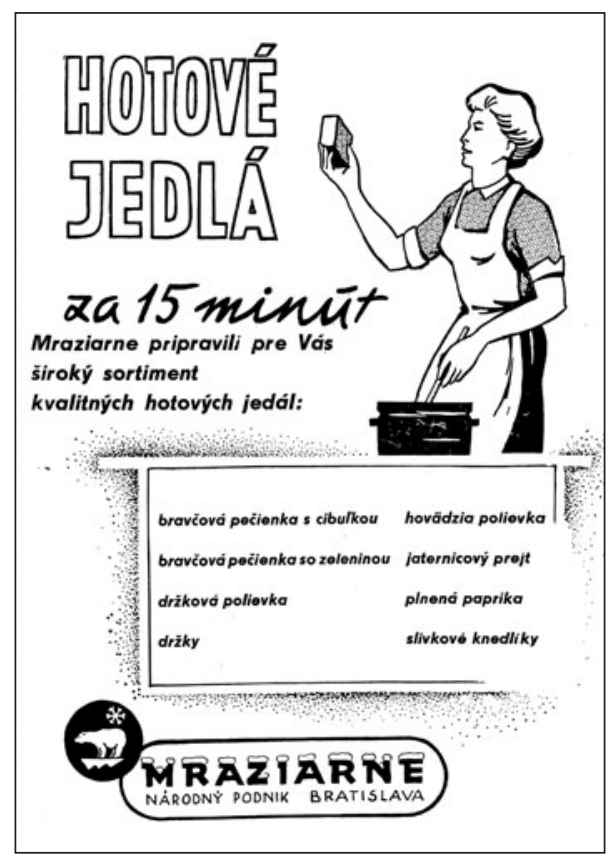

do nadojeného mlieka vodu (Kršek: 2010, 32). Dlhodobo pôsobila masívna kampaň za zvýšenie spotreby mlieka a mliečnych výrobkov a zavádzali sa aj mliečne desiate pre deti do škôl. Zdravotné argumenty boli kombinované s ekonomickým faktorom, pretože produkcia mliečnych bielkovín je lacnejšia než produkcia bielkovín mäsa a vajec (Franc: 2003, 69 - 70). Nízka cena mlieka - 2 Kčs za 1 liter - sa preto udržiavala dlhé obdobie umelo.

Postupne sa začali priemyselne vyrábat' viaceré mliečne potraviny, z ktorých niektoré sa zachovali na trhu dodnes alebo aspoň rezonujú v pamäti ludí ako socialistické výrobky. Bolo to napríklad sušené mlieko pre dojčatá SUNAR, ktorého názov bol vyskladaný zo slov "sušený“ a "národný“, d’alej tvarohový krém pre deti - vanilkový alebo kakaový MILÁČIK, zahustená smotana v paste JESENKA, kondenzované mlieko v plechovke alebo v tube PIKNIK. 
Mlieko sa v 50. rokoch 20. storočia distribuovalo v tažkých kovových kanvách, z ktorých sa naberalo do plechových bandasiek pomocou plechovej naberačky s objemom 0,25 1 alebo 1/5 1. Mliekarne mali pultový predaj a boli charakteristické osobitým pachom starého rozliateho mlieka. Postupne sa prešlo na predaj mlieka, smotany, šlahačky a jogurtov v sklených flašiach. Mlieko sa predávalo v jednolitrových, smotana a šlahačka v pollitrových a jogurty v štvrtlitrových flašiach s hliníkovými uzávermi, na ktorých bolo farbami označené percento obsiahnutého tuku. Mlieko sa hned' preváralo, aby neskyslo. Ak sa nechalo dlhšie stát, zrazilo sa na kyslé mlieko, z ktorého sa v prípade potreby dal po domácky vyrobit tvaroh. Mlieko v prepravkách stálo často už skoro ráno pred predajňami, takže sa stávalo, že noční "flamendri“, ktorí sa vracali z krčiem alebo vinární, sa sami „obslúžili“. L’udia vo väčších mestách si mlieko a pečivo mohli objednat’ ako donášku do domu a ráno pred dverami si objednaný tovar našli. Mlieko v polyetylénových jednolitrových vreckách sa začalo v Československu dodávat’ do obchodov v roku 1969, čo predaj mlieka zjednodušilo (l'udia nemuseli umývat' sklené flaše a nosit' ich do obchodu na výmenu za plné), ale bol to vel'mi nehygienický spôsob - vrecká často praskali, mlieko z nich vytekalo a domácnost' musela mat’ plastikovú nádobu s rúčkou, aby sa dalo s plným vreckom manipulovat'. Až v 80 . rokoch 20 . storočia sa začalo mlieko postupne plnit’ do trvanlivých tetrapakových kartónových obalov tak, ako to poznáme dnes. Jogurt sa predával pod názvom JOVO čistý alebo navrchu s džemom. Aj jogurty sa postupne začali plnit do priesvitných plastikových pohárov. Velmi populárnym sa stal tzv. smotanový jogurt, ktorý mal menej kyslú chut'.

Spotreba mlieka sa mala saturovat’ aj zvýšenou konzumáciou mliečnych produktov, predovšetkým syrov. Tvrdé syry mali zároveň nahrádzat’ problematické údeniny pri studených večerách. Populárnym bol najmä syr EIDAM, ktorý sa predával nízkotučný v červenom a tučnejší v žltom obale, a drahší syr EMENTÁL, ktorý musel byt’ po roku 1976 na žiadost̉ Švajčiarska premenovaný na PRIMÁTOR. Z plátkov týchto syrov sa pripravovalo populárne 




jedlo, vyprážaný syr, ktorý sa podával s varenými zemiakmi a tzv. tatárskou majonézovou omáčkou. Oblúbené boli aj syry s ušlachtilou plesňou NIVA, HERMELÍN, ROMADUR, OLOMOUCKÉ SYRČEKY, ČEDAR, PIVNÝ SYR, ZLATO. Mliekarenský priemysel vyrábal aj mäkké tavené syry, napr. BAMBINO, KARIČKA, JÁNOŠÍK, KOLIBA, TRENČAN, KOMINÁRIK, IMPERIÁL, LUNEX, ktoré sa dali natierat' na chlieb. Často bývali ochutené, napríklad šunkou, cibul'ou, zeleninou, korením. V Bratislave v obchodnom dome Dunaj bol oblúbený obchod "Syry“, kde ich predávali na váhu, podobne aj bryndzu, mlieko, smotanu, jogurty, maslo či tvaroh. Z hladiska výživy bol vyzdvihovaný tvaroh s vysokým podielom bielkovín, predávaný za nízku cenu. Limitujúcim faktorom pri jeho spotrebe bola úroveň jeho spracovania $\mathrm{v}$ mliekarenskom priemysle a prob- 
lémy s distribúciou, ked' sa do mnohých dedinských predajní ani nedodával s tým, že si ho rolníci môžu vyrobit sami. Od roku 1976 sa začal vyrábał' TERMIX - ochutený tvarohový krém. V 80. rokoch 20. storočia došlo na trhu k situácii, ked’ sa prejavil nedostatok mliečneho tuku - smotany, šl’ahačky a masla. Mliekarenský priemysel na to reagoval výrobou NÁTIERKOVÉHO MASLA, ktoré obsahovalo menej tuku a bolo alternatívou k maslu (www. ceskatelevize/porady/retro). Tento výrobok je pod rôznymi názvami oblúbený medzi obyvatel'stvom dodnes. Na Slovensku bol dopyt aj po tradičnom ovčom syre - bryndzi, ktorá však v čase socializmu, ked’ sa vyrábala v mliekarenských továrňach, nemala dostačujúcu kvalitu, býval jej nedostatok a predávala sa na váhu z geletiek. Oštiepky, parenice či korbáčiky sa v obchodoch vôbec nepredávali, dali sa kúpił’ len od priekupníkov, ktorí ich ponúkali priamo na uliciach miest. V Bratislave napríklad pod Michalskou bránou. V roku 1989 bola spotreba mliečnych produktov v Československu 260 kg na osobu, čo bol solídny svetový priemer.

Čo sa týka propagácie vajec v strave, boli badatel’né silne tendenčné pohl'ady odborníkov. Vedl’a ich sezónnosti tomu nahrávalo aj pomerne komplikované zloženie vajec zo zdravotného hl'adiska. Na jednej strane sa o nich hovorilo ako o najdokonalejšej bielkovine a v časoch, ked' na trhu bol nedostatok mäsa, sa o nich písalo ako o jeho vhodnej a plnohodnotnej náhrade. V prípade ich nedostatku na trhu sa zasa akcentoval nežiaduci vysoký podiel cholesterolu v nich (Gažo: 1958, 86). V oboch prípadoch reklamné heslá hlásali: "Jedno vajce denne!“

Odborníci na výživu a dobová reklama sa upriamili aj na zvýšenie konzumácie rýb ako dôležitého zdroja živočíšnych bielkovín. Pri morských rybách sa zdôrazňoval predovšetkým obsah jódu a vitamínu D, ktorých bolo v stredoeurópskej strave nedostatok. V 50. rokoch 20. storočia zohrala vážnu rolu i skutočnost', že ryby ako pokrm odporúčal sovietsky guru vied o výžive I. P. Pavlov. Morské plody boli však u nás potravinou úplne neznámou. Československý trh bol zásobovaný najmä zo Sovietskeho zväzu rybím mrazeným 


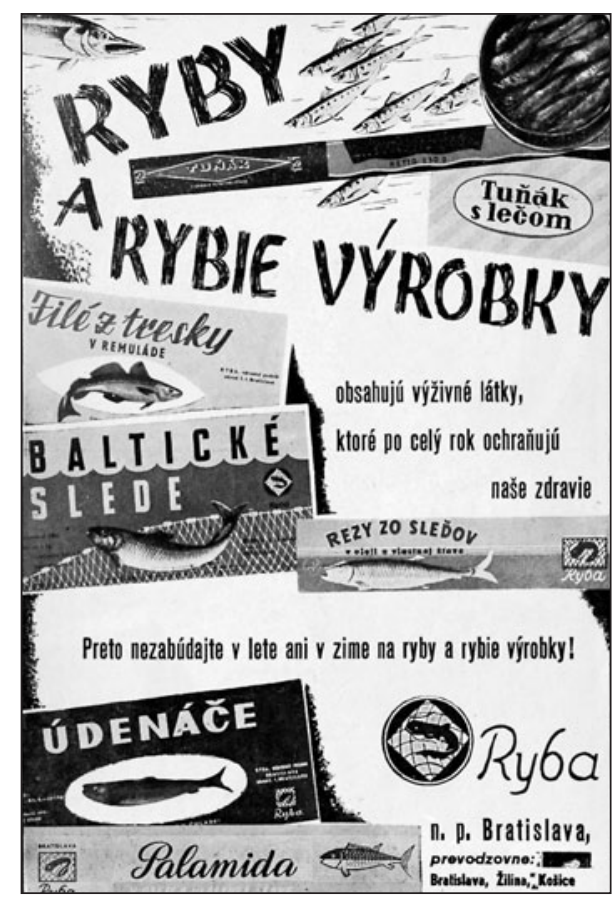

filé z tresky a rybími konzervami, predovšetkým baltickými sled’mi. Lacné a kvalitné boli napríklad sardinky, šproty a kaviár. Reklamný slogan hlásal: „Sardinky, pozdrav dial'av.“ Koncom 60. rokov 20. storočia paradoxne dovoz morských rýb na československý trh poklesol a cena rýb narastala (Franc: 2003, 80 - 84). V tejto situácii sa uvažovalo, ako z mála rybieho filé urobit čo najviac, a tak sa firma „Ryba“ pokúsila urobit’ chutný šalát s využitím tresky a majonézy. Toto jedlo s čerstvým pečivom sa stalo počas socializmu skutočnou ikonou našej gastronómie.

Vela sa písalo aj o tradícii a rozširovaní chovu sladkovodných rýb a ich žiaducom podiele v jedálnom lístku, avšak verejnost’ tomu nechcela načúvat. Ryby boli vnímané ako „hladové jedlo“, ktoré človeka nenasýti, na druhej strane l'udia nevedeli ryby ani vhod- 
ne upravovat'. Čerstvé ryby, predovšetkým kapor, sa vo väčšine domácností konzumovali jedenkrát za rok, počas Štedrej večere na Vianoce. Tento trend pretrvával aj v nasledujúcich desatročiach a jeho dozvuky vnímame aj v súčasnosti.

Napriek svojej významnej pozícii v tradičnej strave strácali svoje postavenie vo výžive socialistického človeka zdroje rastlinných bielkovín - strukoviny. V obchodoch často chýbala šošovica alebo fazula. Socialistická propaganda sa teda zamerala na konzumovanie hrachu, ktorého bol prebytok, a odporúčala ho v časoch, ked’ bol nedostatok mäsa. Odborníci vel’mi kritizovali úpravu strukovín pridávaním sódy bikarbóny, aby rýchlejšie zmäkli, čo sa stalo jedným z učebnicových príkladov zlých návykov kuchynskej úpravy potravín (Franc: 2003, $84-85$ ).

Symbolom boja proti nezdravej a zároveň ideologicky nevhodnej strave sa stali biely chlieb a biele pečivo. Počiatkom 50. rokov 20. storočia sa dokonca vyskytli názory, že konzumácia bieleho chleba priamo ohrozuje československý l'udovodemokratický štát, pretože ten musí za drahé ceny nakupovat’ obilie v cudzine. Preferovaný bol preto chlieb tmavý, ktorý obhajovali tak lekári, ako aj ideológovia. Kritizovali sa najmä názory západných vedcov, že nárast spotreby bieleho chleba je prirodzeným dôsledkom civilizačného vývinu, a problém sa preniesol až do roviny ideologického konfliktu medzi Západom a Východom. Upozorňovalo sa aj na bielenie múky v čase 1. ČSR ako nástroja vel'kokapitálu na zbohatnutie. Napriek všetkým apelom došlo v 50. a 60 . rokoch 20 . storočia k výraznému poklesu produkcie a spotreby raže ako hlavnej chlebovej obilniny, potrebnej na výrobu tmavého chleba a pečiva. Chlieb sa predával dvojkilový okrúhly alebo podlhovastý, nebalený, a krájali ho predavačky nožom alebo špeciálnym krájačom na polovice alebo štvrtky. Väčšinou boli len dva druhy chleba: svetlý a tmavší, tzv. výražkový. Lepší chlieb sa dal kúpit’ v menších pekárňach, kde sa snažili piect' podl'a starých receptov. Medzi obyvatel'stvom vítazila viac konzumná prestíž reprezentovaná bielym chlebom, než stanoviská obhajujúce konzumáciu tmavého chleba. Sladené a tučné biele pečivo, tzv. lú- 
pačky a šatôčky, ktoré tvorilo oblúbenú súčast’ stravy obyvatel'stva, bolo, samozrejme, podobne ako cukrárenské výrobky, silne kritizované a ich konzumácia sa považovala za vážny dietetický problém. Biele žemle a rožky mali byt' nahradené alebo aspoň doplnené zdravším pečivom - tzv. bosniakmi alebo grahamovými rožkami.

„...Známa pekáreň v Bratislave bola na Obchodnej ulici. Každých dvadsat' minút vysypali plnú debnu dobrého pečiva. Piekli sa tu vynikajúce pletienky posypané kryštálikmi soli a rascou, obyčajné rožky, vodové žemle, bosniaky. Rad stál až na ulicu. Pletienky sme jedli ešte za tepla a zapíjali kofolou..." (Šebo: 2010, 74).

Medzi odborníkmi sa tiež diskutovalo o možnosti využitia d’alších tradičných, ale pomaly zabudnutých obilnín, ako boli ovos, jačmeň, proso, pohánka alebo tenkel. Pokusy o návrat týchto obilnín do stravovacieho systému môžeme zaznamenat’ v dobovej produkcii instantných ovsených kaší AVENA a KALORKA, no inak sa nepresadili.

Príliš vysoká spotreba obilnín, ako aj tukov viedla postupne k nárastu obezity a d’alších civilizačných chorôb u obyvatelov Československa, s čím sa naša spoločnost' vyrovnáva dodnes (Franc: 2003, 86 - 95; Hrubá: 1963, 168; Zápotocký: 1965, 49 - 51).

Vel'kým problémom obdobia socializmu bola vysoká spotreba cukru v strave, čo odborníci na výživu kritizovali ako potravinu s prázdnymi kalóriami, ktorá okrem energie nedodávala organizmu žiadne biologicky cenné látky a bola d’alším faktorom nárastu obezity. Napriek tomu spotreba cukru mala neustále stúpajúcu tendenciu. Napríklad v roku 1962 sa jeho spotreba oproti roku 1936 zvýšila o $15 \mathrm{~kg}$ ročne na osobu. Cukor patril k potravinám, kde sa predstavy odborníkov na výživu a socialistických ekonómov zásadne rozchádzali. Zástupcovia potravinového priemyslu a Štátnej plánovacej komisie sa stavali proti redukcii výroby cukru vzhl'adom na vel'ké rozlohy pestovanej cukrovej repy a nevýhodný export cukru z krajiny. Zo sociálneho hladiska zasa sezónna kampaň spracovania cukru v cukrovaroch od jesene do jari dávala prácu mnohým mužom zo slovenského vidieka, ktorí chodili na tieto práce (hlavne 




do Čiech) často aj desatročia, pretože tam si mohli slušne zarobit’ (Stoličná: 2005, 30). Len zriedka sa odborníci zmieňovali o mede ako tradičnom sladidle. Dôvodom bola nízka produkcia medu, spôsobená najmä postrekovaním rastlín jedovatým insekticídom DDT, čo viedlo k záhube včelstva (Franc: 2003, 95 - 99).

Odborníci na výživu kritizovali aj nedostatočný konzum ovocia a zeleniny ako najdôležitejšieho zdroja vitamínu C, ktorý sa v prvých desatročiach budovania socializmu neustále prehlboval. Nádej na zlepšenie očakávali od nárastu ovocinárskej a zeleninárskej vel'kovýroby, produkcie konzervární a závodného a školského stravovania. V súvislosti so spotrebou ovocia a zeleniny sa v textoch odborníkov často objavoval protiklad sivého kamenného priemyselného mesta bez kúska zelene a vidieka ako rajskej záhrady, kde aj ten najchudobnejší človek sa dostal k potrebným vitamínom. Propagácia spotreby ovocia a zeleniny mala svoje výkyvy podl’a aktuálnej situácie na trhu, pretože základným zdrojom zostávala domáca, 


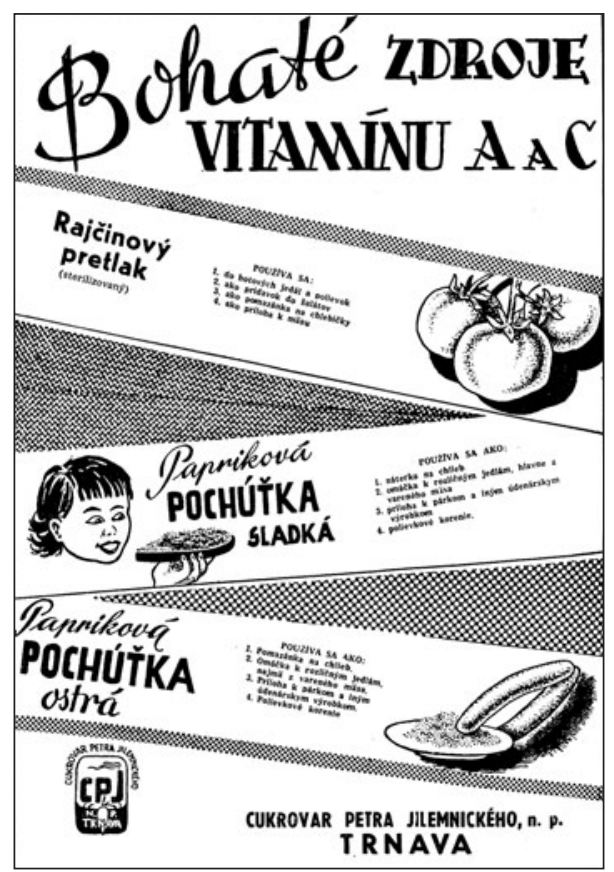

vel’mi často nedostačujúca produkcia. Práve pri zelenine a ovocí sa jasne ukazovalo, že vel'kovýroba nie je najlepším riešením, a muselo sa pripustit’ zapojenie drobných pestovatel'ov - záhradkárov do systému zásobovania, prípadne zakladanie menších špecializovaných hospodárstiev pri továrňach, školách, domovoch dôchodcov, nemocničných zariadeniach a podobne. Aj v čase socializmu sa kritizovala nedostatočná spotreba zeleniny, ked' realitou odporúčaných $103 \mathrm{~kg}$ na osobu a rok bola len polovičná spotreba (www. ceskatelevize/porady/retro).

Vel'ké problémy boli aj s distribúciou ovocia a zeleniny. Často sa na pultoch objavovala silne zahlinená koreňová zelenina. Ovocie sa predávalo netriedené, všetko za rovnakú cenu. Tradičné drobnejšie ovocie (ríbezle, jahody, maliny, egreše a pod.) sa na pulty zelovo- 
cov nedostávalo vôbec. Problematika nedostatku ovocia a zeleniny mala úzky súvis aj s relatívne malým podielom importu týchto potravinových komodít (Franc: 2003, 99 - 105). Pomaranče dovážané z Kuby neboli príliš vhodné na jedenie, zle sa šúpali a využit’ sa dala často len štava $\mathrm{z}$ nich. Do Československa sa okrem citrónov a pomarančov priviezlo niekol'kokrát do roka aj iné exotické ovocie, väčšinou banány a mandarínky, na ktoré sa stáli, najmä pred Vianocami a inými sviatkami, dlhé rady. Toto ovocie sa tiež používalo ako lákadlo pre l’udí, aby prišli do prvomájových sprievodov. Záchranou mestských obyvatelov boli trhy, kde sa dala kúpit’ zelenina a ovocie z domácej produkcie od záhradkárov alebo súkromných rol’níkov. „V Bratislave na trhoviskách predávali tetušky často ešte v polokrojoch voňavú zeleninu, ovocie, husi, kačice, kurence, kyslú kapustu a pod., vládla tam vždy zvláštna atmosféra a chodili tam nakupovat’ známe osobnosti aj obyčajní l'udia" (Šebo: 2009, 24).

Problémy so zásobovaním boli aj s takou bežnou potravinou, ako sú zemiaky alebo cibul'a. Nedostatok zemiakov sa ideologicky zval'oval na záškodnícku akciu kapitalistov zo Západu, ktorí mali na československé polia vypúštał’ z lietadiel alebo pomocou diverzantov chrobáky - pásavku zemiakovú, ktorá žrala zemiakové vňate, následkom čoho rastlina uhynula. V 50. rokoch 20. storočia sa tento chrobák (lat. Leptinotarsa decemlineata) na Slovensku nesprávne nazýval mandelinka zemiaková, ale dostal aj prezývku „imperialistický“ alebo „americký“ chrobák. Tieto chrobáky l'udia chodili do zemiačnísk povinne zbierat'. Jej kalamitné rozšírenie bolo však v tej dobe v celej Európe a nemalo nič spoločné s diverziou Západu. U nás išlo pravdepodobne aj o nedodržiavanie agrotechnických postupov pri vysádzaní zemiakov družstevníkmi, čo súviselo $\mathrm{s}$ presadzovaním pestovania rastlinných monokultúr. V tejto situácii bol aj zber zemiakov považovaný komunistickým režimom za taký dôležitý, že družstevníkom museli dlhé roky povinne pomáhat’ zberat' úrodu školáci, študenti a tzv. pracujúca inteligencia. Boli to tzv. zemiakové brigády, ktoré mali zabezpečit', aby sa zemiaky dostali čo najskôr na stôl pracujúcemu l’udu. 
O tom, aký bol v ére socializmu pre rodiny významný nákup a zásobenie sa zemiakmi, názorne vypovedá príspevok autora L. R., ktorý zverejnil na internete: „...V zelovoci majú dostat' zemiaky, ktoré sme si dopredu objednali. Najpro treba jednej predavačke nahlásit meno, ktorá ho vyhladá v zozname a vydá pokladničný blok, ktorý je aj dokladom o tom, kol'ko vriec zemiakov dostanete. Treba si dobre rozmysliet', kol'ko vriec si objednáte, ked' sa zemiaky minú, d’alšie už nebudú. Zemiaky sa mínajú hlavne cez víkendy a občas počas týždña na večeru. Predvlani sme doma jedli vyše mesiaca len ryžu a cestoviny, až kým neboli nové zemiaky. Uskladnené zemiaky nám pohnili, boli vlhké, ked'sme ich kupovali, asi ich zberali v daždi. Zemiaky sa rýchlo mínajú a my ešte stále stojime v rade. Zo služobných dverí zelovocu, za pultom, vykukne dobre oblečený pán. ,Hned' to bude, súdruh vedúci,' povie predavačka. Je to vedúci autoservisu. Na chvil'u prestanú platił všetky pravidlá. Meno tohto pána netreba hl'adat' v zozname, povie si počet vriec a predavačky mu ich naložia na vozík. L'udia šomrú, ale nahlas sa neodváži povedat nikto nič. Konečne prichádza rad na nás. Zemiaky vysypeme z vriec na betónovú plochu pred panelákom. Preberáme ich. Poškodené, nahnité, nakrojené, zelené, príliš vel'ké alebo malé, dávame bokom. Zelené zemiaky sa vyhodia, pretože sú jedovaté, ostatné sa upotrebia ako proé. Zdravé stredne vel'ké zemiaky idú do pivnice, do pripraveného násypníka. Počas zimy bude treba zemiaky kontrolovat', odstraňovat kličky, vyhadzovat' nahnité. Sme spokojní, zásobili sme sa na d'alšiu zimu..."

Spotrebu zeleniny a ovocia sa odborníci snažili ovplyvnit aj rozširovaním konzervačných technológií. Typickým socialistickým výrobkom sa stal mrazený špenátový pretlak, ktorý zjednodušil prípravu špenátu (Franc: 2003, 106). V školských jedálňach býval spolu s vajíčkom častým (ale u mnohých detí velmi neoblúbeným) obedovým chodom. Obchod však sortimentom a kvalitou ovocných a zeleninových výrobkov ludí vel'mi neuspokojoval. $\mathrm{V}$ ére socializmu sa radšej spoliehali na vlastné výrobky: pripravovali si kompóty, džemy, lekvár, čalamády, paradajkový kečup, nakladané uhorky aj kyslú kvasenú kapustu. Tieto výrobky, najmä kyslá kapusta, sa nakupovali aj na trhu. 


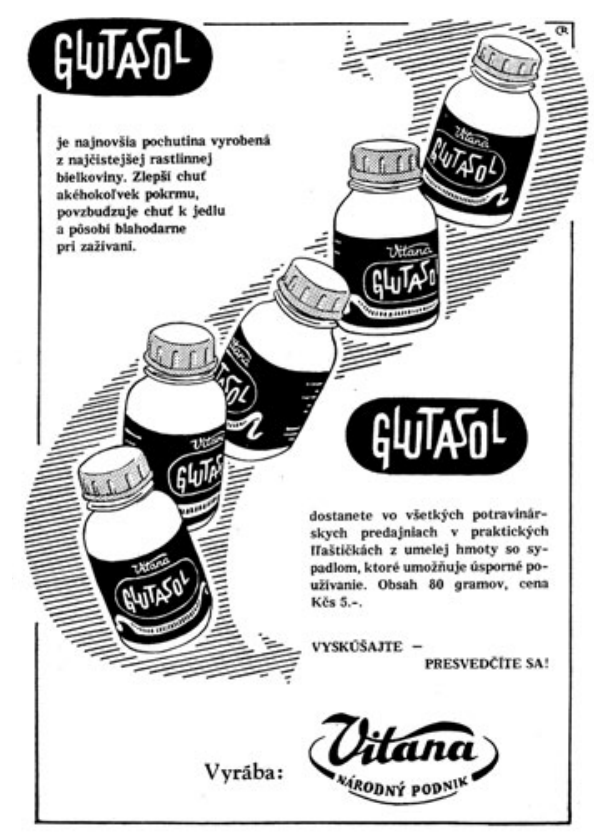

Čo sa týkalo korenín a d’alších prostriedkov potrebných na varenie, to v socialistickom Československu zabezpečovala produkcia firmy Vitana, ktorá vznikla znárodnením firiem Maggi a Franc v roku 1950. Vyrábala tekuté polievkové korenie, instantné bujóny a polievky, koreninové zmesi, rôzne chutové esencie, balila korenie a pod. Socialistickým vynálezom tejto firmy bola GLUTASOL, ktorá sa odporúčala na zlepšenie chuti všetkých slaných pokrmov. Vitana vyrábala aj BURISONY, čo bola potravina pripravená z navlhčenej ryže, ktorá sa vystrel'ovala do kovových sít, aby nadobudla žiadaný tvar a chut'.

Aj počas socializmu l’udia radi kupovali a konzumovali sladkosti. V roku 1948 boli znárodnené všetky výrobne aj týchto potravinárskych komodít a štyridsat závodov v Československu vyrábajúcich čokoládu a cukríky sa zredukovalo na osem, do ktorých sa skon- 




centrovala výroba. Najznámejšími firmami boli Orion, Figaro, Deva, ktoré vyrábali aj na export a pre domáci trh čokolády, čokoládové bonboniéry, vianočné kolekcie, salónky, tvrdé i mäkké cukríky. K známym socialistickým výrobkom z čokolády patrili napríklad tyčinky KOFILA s typickým obrázkom sediaceho Turka, GAŠTANY, DELI, DEVA, MILENA s obrázkom dievčatka v červenej šatke, BANÁNY V ČOKOLÁDE, MAČACIE JAZÝČKY, MARGOT, RUMBA, z cukríkov napríklad ČOKOLÁDOVÝ DROPS, LENTILKY, ktoré sa v Československu vyrábali už od roku 1921 a vždy sa aj exportovali. Najprestížnejšie boli ručne balené čokoládové bonboniéry, napríklad višne v čokoláde. Čokoládové vianočné kolekcie boli tradičnými darmi Revolučného odborového hnutia $(\mathrm{ROH})$ na 
pracoviskách rodičom, ktorí mali deti (Príloha Nového času, 14. 4. 2014, 16 - 17).

Z d’alšieho sortimentu cukríkov a iných sladkostí patrili medzi najoblúbenejšie a lacné napríklad PELENDREK, ktorý sa predával na váhu. Boli to čierne lepkavé pásiky, ktoré mali osobitú korenistú vôňu. Na váhu sa predával tiež KRUMPLCUKOR, ktorý vyzeral ako tabul'ka čokolády, ale mal bielu alebo ružovú farbu. Populárne boli karamelové polomäkké ŠTOLVERKY a neskôr sa objavili podobné ružové cukríky SI-SI. Deti oblubovali LÍZATKA, TURECKÝ MED, SÓJOVÚ TYČINKU. Oblúbené boli aj "gumené“ a želé cukríky, ako aj citrónové a pomarančové želé polmesiačiky v darčekovej bonboniére.

Osobitnou kapitolou boli žuvačky, ktoré v prvých rokoch budovania socializmu symbolizovali "skazený“ kapitalizmus USA, a preto sa z ideologických dôvodov nevyrábali. Aj vtedajší režim však kapituloval pred túžbou l'udí po takomto artikle a rozhodol sa výrobu žuvačiek povolit'. Prvé sa začali vyrábat’ v roku 1956, avšak neuspokojovali svojou kvalitou. Preto sa v roku 1968 prešlo na výrobu nových druhov žuvačiek PEDRO s vyobrazeným Mexičanom na obale a SEVAK, čo boli tzv. zdravotné žuvačky, ktoré mali chránit’ ludí pred nachladením a angínou. V továrni Velim sa ich vyrobilo 900 ton ročne a Čechoslováci stihli všetky skonzumovat. Naše žuvačky na rozdiel od západných strácali rýchlo chut', napriek tomu ich najmä deti dokázali žut’ dlhé hodiny a niekedy aj dni. V roku 1984 sa začala výroba d’alších druhov žuvačiek BAJO a PING. Boli zabalené spolu s obrázkami z večerníčkovských televíznych seriálov a deti ich s obl'ubou zbierali (www. ceskatelevize/porady/retro).

Po celú dobu socializmu bolo však vecou prestíže mat žuvačky zo Západu, ktoré sa kupovali v Tuzexe alebo pochádzali z kapitalistickej cudziny. J. Šebo vo svojej knihe spomienok na socializmus o tom napísal: „...V V̌etko, čo súviselo so Západom a osobitne s Amerikou, bolo v mojom detstve vel'mi hl'adané a cenené. Žuvačku sme pokladali za symbol Ameriky. Dostat’ sa k pravej americkej žuvačke nebolo jednoduché. Naším dodávatelom bola dobrosrdečná stará pani Aranka Nény, ktorá 
bývala oproti škole. Mala syna v Amerike, ktorý jej okrem iného posielal aj žuvačky. Zrejme z toho dôvodu, aby si tak mohla privyrobit’ k malému dôchodku. Jedna žuvačka u nej stála 1 korunu, ale to bolo pre nás drahé. Hladali sme náhradné riešenia. Niekto žuval vosk, niekto skúšal smolu zo stromov, ktorá však bola vel'mi horká. Občas sa nám podarilo získat’ naozajstnú americkú žuvačku, a vtedy sme ju žuli v proej fáze až do straty chuti a potom až do rozpadu hmoty. Nechápali sme, ako môžu Američania vypl'ut’ žuvačku hned’ potom, ako stratí chut'. Bežné bolo aj posielanie žuvačky tzv. z huby do huby. Niektorí učitelia naše žuvanie prenasledovali a museli sme ich vyhodit' von z okna. Hned' ako sa dalo, sme ich išli hl'adat' a žuvali sme veselo d’alej. Na hodinách bolo preto bezpečnejšie žuvačku si nalepit’ za ucho..." (Šebo: 2010, 188).

K oblúbeným pochútkam patrili aj rôzne oblátky, sušienky, perníky, piškóty a trubičky, ktoré sa na Slovensku vyrábali od roku 1953 v továrni v Seredi a jej pobočkách v Holíči, Pieštanoch, Leviciach, Teranoch, Brodzanoch, Kremnici, Ružomberku a Liptovskom Hrádku. Od roku 1959 sa v tejto prevádzke vyrábal jej najpopulárnejší výrobok HORALKA, ktorý nadviazal na povojnovú tradíciu výroby TATRANKY. Oba výrobky sú podobné, ale líšia sa náplňou. Prvý produkt je plnený arašidovou plnkou a druhý plnkou z lieskových orieškov (www.sedita.sk). Ďalšie známe socialistické výrobky boli napríklad KÁVENKY,VLNKY, Marína KEKSY, VENČEKY, KRYŠTÁLKY, ESÍČKA, PETIT-BEURRE, PRINCEZKY, KOKOSKY, tortové oblátky či BB puding. V roku 1956 seredská fabrika produkovala 80 druhov týchto výrobkov (Kotman: 1956, 63).

Oblúbenou činnostou rodín cez víkend od jari do jesene za socializmu bolo „íst’ na zmrzlinu“. Najlepšiu zmrzlinu predávali balkánski výrobcovia pod názvom JADRANSKÁ ZMRZLINA. Na tú boli l'udia ochotní čakat’ v dlhých radoch. Spočiatku zmrzlinári predávali pojazdne zo zásobníka, ktorý mali pripevnený na bicykli, a upozorňovali na seba zvonením zvončeka. Zmrzlinu naberali pomocou malej kovovej lopatky. Neskôr predávali na stabilných miestach. V Bratislave bolo niekol'ko takýchto predajcov, napríklad v dome ned’aleko Dómu sv. Martina, vo dvore domu oproti hotelu Kyjev, 


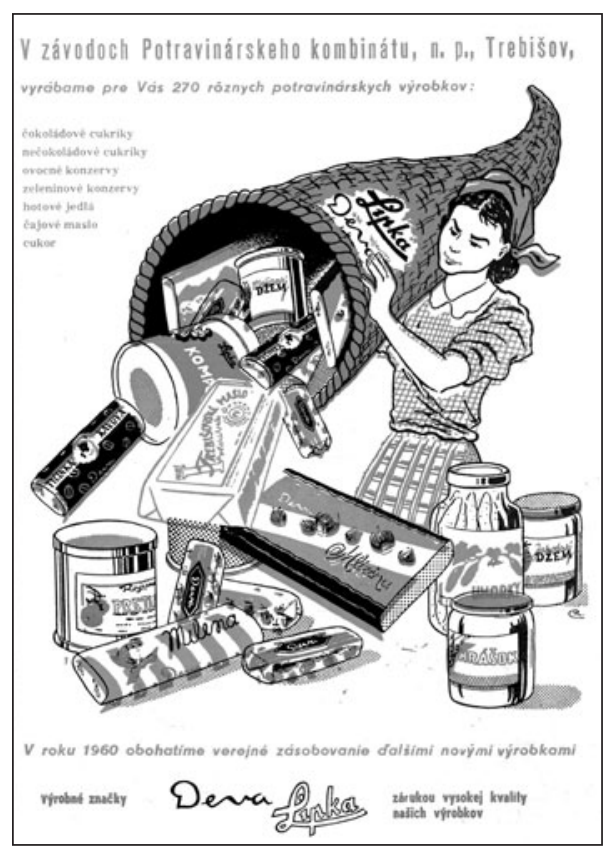

v tzv. ,jame" pri dnešnom Národnom tenisovom centre alebo v súkromnom dome ned’aleko Patrónky. K najznámejším patril Čazim Razim. V cukrárňach sa zmrzlina predávala „kopčeková“ a neskôr aj točená zo strojov. Bývala vodová i smotanová, najčastejšia vanilková, čokoládová alebo jahodová. Zmrzlina a iné mrazené výrobky sa vyrábali aj továrensky. Oblúbené boli nanukové, vanilkové alebo kakaové torty, vanilková POLÁRKA, jahodová dreň, MÍŠA, ESKYMO, ASKOT, NANUK na drevenej paličke. Dovážala sa kvalitná ruská zmrzlina MOROŽENOJE. Zmrzlinové poháre sa predávali v cukrárňach alebo v lahôdkarstvách (www. ceskatelevize/porady/retro).

V nedel'u poobede sa zvyklo v mestách chodit’ do cukrárne na zákusky a kávu. Za socializmu sa ceny v týchto predajniach dotovali a zákusky boli lacné. K oblúbeným patrili napríklad PUNČOVÉ REZY, KRÉMEŠE, ŠAMROLE, VENČEKY, KOŇAKOVÉ ŠPIČKY, 


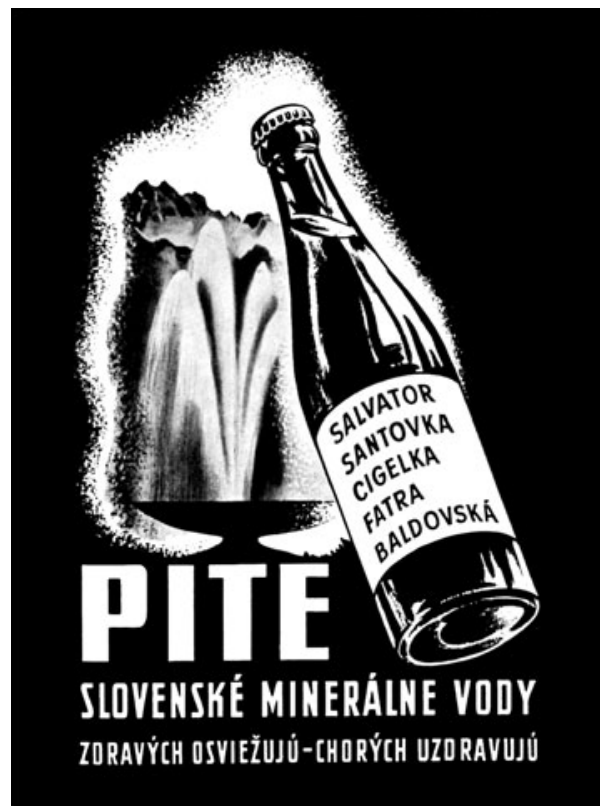

LASKONKY, KOKOSKY, INDIÁNKY, PIŠKÓTOVÝ CHLEBÍČEK SO ŠLAHAČKOU, KUBA REZY, DOBOŠKY.

$\mathrm{V}$ tomto období postupne najmä mestské ženy pomaly začali upúštat od pečenia zákuskov a tort a kupovali ich v cukrárňach. Avšak domáce pečenie vianočného pečiva prežívalo $\mathrm{v}$ domácnostiach aj v časoch socializmu a patrilo ku koloritu sviatočnej atmosféry. V Bratislave sa chodilo najmä do tzv. Deky - Detskej cukrárne pri Slovenskom národnom divadle, v ktorej bol nízky nábytok pre deti. Táto cukráreň mala aj $\mathrm{v}$ časoch socializmu, jednotných cien a receptúr podstatne kvalitnejšie a väčšie zákusky ako konkurencia v d’alších cukrárňach (Šebo: 2008, 120).

Pomerne vel'ké problémy sa prejavovali pri zásobovaní obyvatel'stva nápojmi, aj ked' odborníci jasne deklarovali, že sa musí výrazne zvýšit konzumácia nealkoholických nápojov a znížit pitie alkoholických nápojov. Napriek množstvu minerálnych prírodných 
prameňov na Slovensku nebola trhom dostatočne saturovaná spotreba minerálnych vôd. K najkonzumovanejším patrili: SALVATOR, SANTOVKA, CÍGELKA, FATRA, BALDOVSKÁ, KORYTNICA. Preto si mnohí l'udia sami chodili naberat' minerálne vody priamo $\mathrm{k}$ prameňom.

Sódová voda sa $\mathrm{v}$ rokoch po vojne ešte rozvážala konskými povozmi vo zvláštnych hrubostenných flašiach. Neskôr sa v domácnostiach vyrábala $\mathrm{v}$ špeciálnych flašiach $\mathrm{s}$ bombičkami naplnenými oxidom uhličitým na sýtenie vody, ktoré sa v obchodoch po použití vymieňali. Zo sódovky sa ochucovaním ovocnými sirupmi robili domáce limonády. Doma sa tiež pripravovali nápoje zo ŠUMIENKY - ovocného koncentrátu vo forme štvorčeka, ktorý sa rozpustil vo vode. Deti však šumienku vel'mi radi skonzumovali aj lízaním. Priemyselne sa vyrábala žltá a ružová malinovka, nazýva-

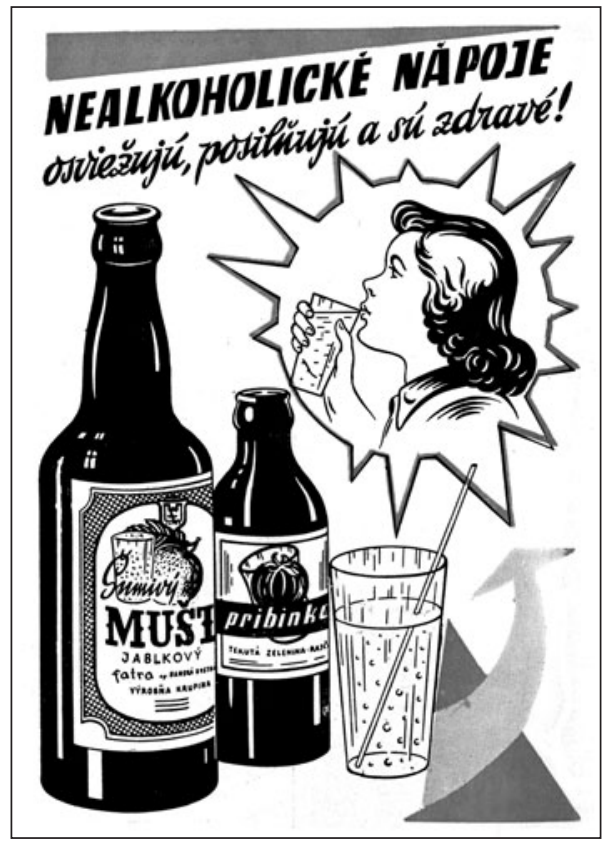


ná KRACHELKA, ktorá sa distribuovala v sklenej flaši s porcelánovým uzáverom a tesniacou gumičkou. J. Šebo vo svojej knihe na tento nápoj spomína takto: „,...Táto limonáda bola nadupaná kysličníkom. Niekedy bol tlak taký obrovský, že sa po uvol'není uzáveru ozvala rana, podobná výstrelu. Limonáda bola tak silno nasýtená, že sa hned’ po otvorení nedala pit’ a potom bublinky šteklili na jazyku. Ne ceste zo školy sme sa v cukrárni zastavovali na krachelku a indiánku. Bol to špeciálny gurmánsky zážitok..." (Šebo: 2010, 223 - 224). Bola vel'mi sladká a rozhodne nespíňala predstavy o zdravom ovocnom nápoji. Tento stav sa pokúsila výroba vyriešit produkciou iných nealkoholických nápojov, napríklad ovocnými muštami či zeleninovou PRIBINKOU. V 60. rokoch 20. storočia sa dostal na trh VITACIT - ovocný koncentrát rozpustný vo vode, nápoj LIMO a KOFOLA, pri výrobe ktorej sa zužitkoval nadbytočný kofeín, vznikajúci pri pražení kávy. Tento

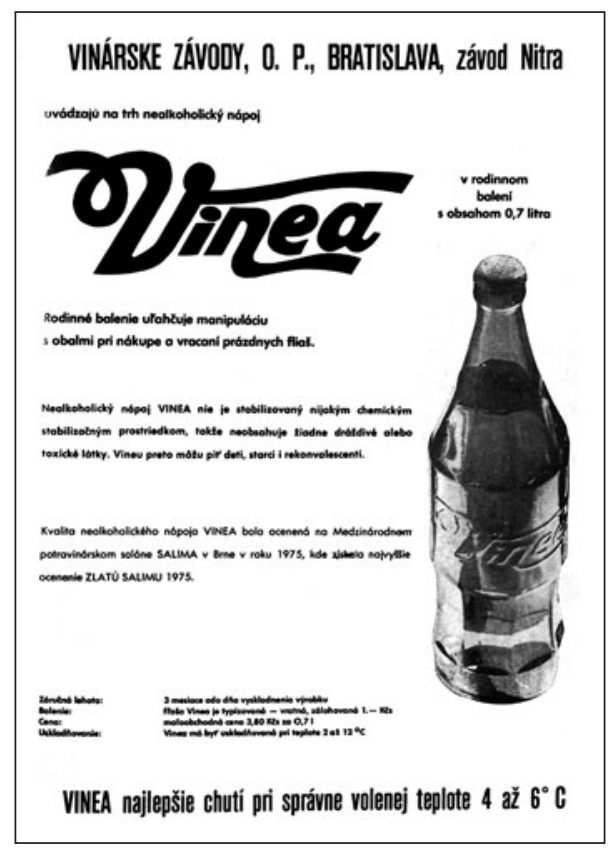




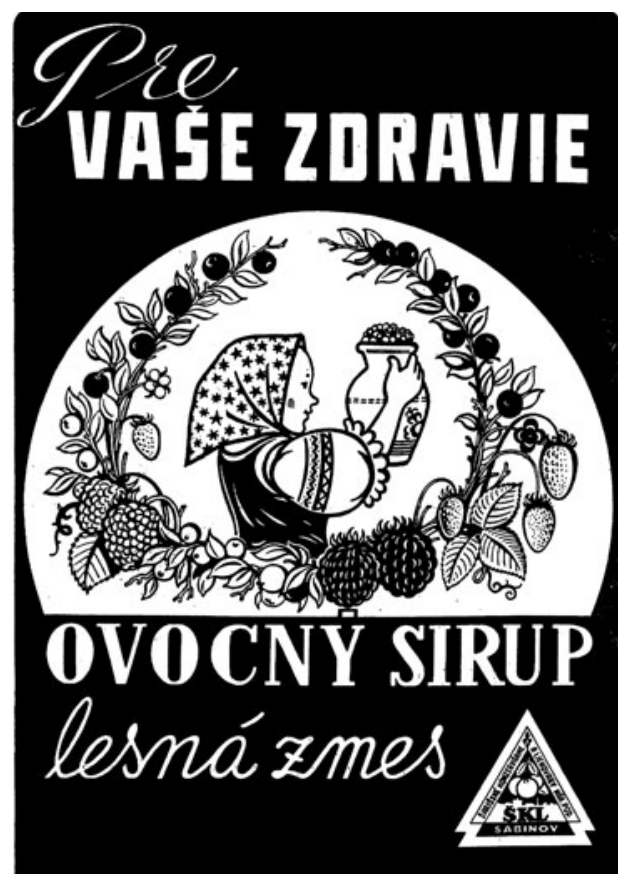

nápoj mal nahradit’ v Československu nedostupné západné „kolové“ nápoje COCA-COLA a PEPSI-COLA. Ďalším socialistickým vynálezom bol nápoj vyrobený na báze hroznového muštu - VINEA, ktorý namiešali slovenskí odborníci a na trh bol uvedený v roku 1974. Tento nápoj bol natol'ko úspešný, že v 80. rokoch sa jeho export do USA zvýšil až tak, že produkcia nebola schopná zásobovat’ domáci trh. Podobne ako KOFOLA aj VINEA si získali vel'kú obl'ubu medzi obyvatel'stvom, a vyrábajú sa dodnes. Postupne sa repertoár nealkoholických nápojov rozširoval o d’alšie domáce produkty, napr. PERLA, OVIT alebo ovocné džúsy v konzervách - PIRUETA, ako aj o licencované nápoje MIRINDA a PEPSI-COLA.

Z d’alších nealkoholických nápojov l'udia v socialistickom Československu konzumovali čaj, predovšetkým jeho zmesky ASIA 


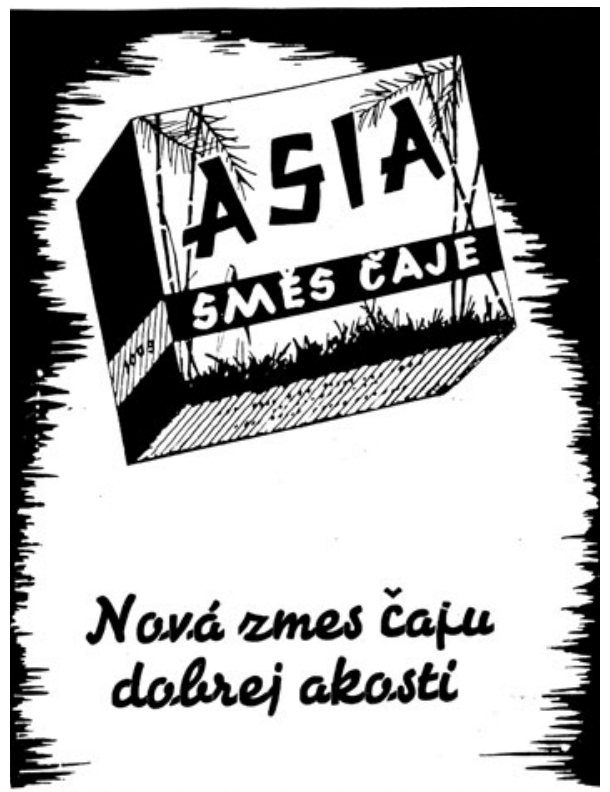

(1B) BALÍR NY A S KLADIŠTLZ

a PIGI, ktorý sa pil často na raňajky, ale nezriedka sa vylepšoval tvrdým alkoholom, napríklad rumom alebo slivovicou, aby "mal silu“. Na raňajky sa často varila kávovina MELTA s mliekom. Spotreba pravej kávy bola u nás najmä v prvých desatročiach budovania socializmu výrazne slabšia ako za 1. ČSR. Najčastejšie sa konzumoval tzv. turek, ktorý sa z mestského prostredia rozširoval aj na dediny, kde sa pil najskôr počas slávnostných príležitostí, ale postupom desatročí už bežne, každodenne. Bola to horúcou vodou zaliata pomletá káva, osladená cukrom, pričom káva z bežných obchodov nebola vel'mi kvalitná. Ked' sa dalo cestovat' do socialistických krajín už vol'nejšie, z Mad’arska si l’udia dovážali špeciálne kovové kávovary na domácu výrobu kvalitnejšej a chutnejšej kávy, ktorá sa robila využitím tlaku vodnej pary, tzv. expreso. Za socializmu sa za- 
čali vyrábat’ GRANKO a MALKAO - granulované príchute nápojov rozpustné v mlieku.

Čo sa týka spotreby alkoholických nápojov, tá zostala aj za socializmu na Slovensku vysoká. Na dedinách fungovali družstevné pálenice, kde si l'udia dávali vypálit’ kvas z ovocia: slivovicu, čerešňovicu, hruškovicu, terkelicu a podobne pre vlastnú spotrebu, ale aj na tajný predaj. Okrem toho si l'udia pálili alkohol napríklad z cukru, raži, zemiakov a cukrovej repy, tzv. samohonku alebo lavórovicu doma aj načierno, hoci to bolo trestné (Stoličná - Nováková: 2012, 115).

Z továrensky vyrábaných silnejších alkoholických nápojov sa kupovali a pili najmä vodka, borovička a tuzemský rum. Ku kvalitným patrila napríklad STOLIČNAJA vodka či arménsky koňak, dovážané zo ZSSSR, alebo SLNCEV BRJAG - bulharské brandy. Na alkohol západnej proveniencie si ludia museli vystát rady pred Tuzexom - obchodoch so zahraničným tovarom. Whisky, koňak, bran-

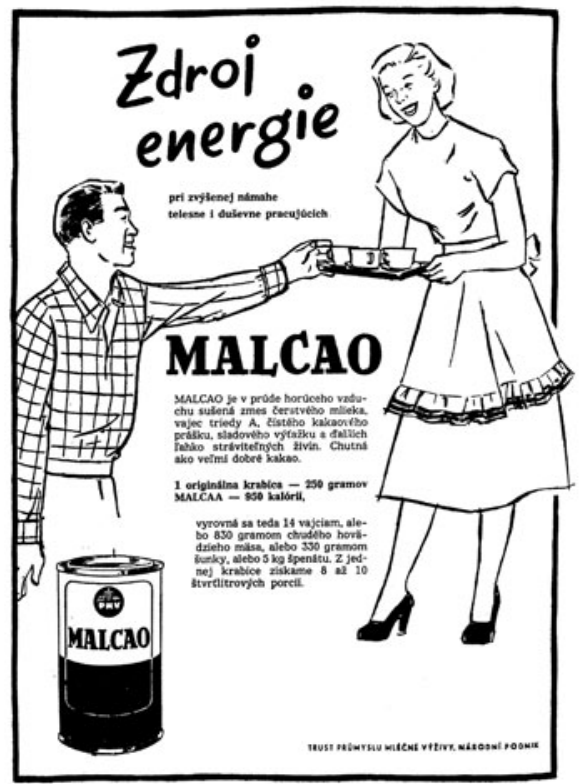


dy, cinzano či bowle boli osvedčené „pod’akovania“ pre lekárov či úradníkov za to, že človeka operovali alebo niečo vybavili.

Vo vinohradníckych oblastiach, v južnom pásme Slovenska, l’udia preferovali konzumáciu vína, ktoré sa tam vyrábalo. Aj v čase kolektivizovaného pol’nohospodárstva bol predaj vína pre l’udí dôležitým finančným zdrojom. Etnologička K. Nováková, ktorá sa vo svojej knihe venovala vinohradníctvu a vinohradníkom v historickej perspektíve 20. storočia v malokarpatskom regióne, o tom píše: „...Hrozno, ktoré si l'udia dopestovali na záhumienkoch a vo vlastných vinohradoch a záhradách, sa snažili spracovat' na víno a predat'. Predaj vína pod rukou sa stal zaujímavým zdrojom finančných príjmov a slúžil na obohatenie rodinného rozpočtu. (...) Preto l’udia vysádzali vinič na každom vol'nom priestranstve..." (Nováková: 2009, 131 - 132). Vel’a l'udí z Bratislavy malo "svojho“ vinára v okolitých vinohradníckych mestečkách a dedinách, ku ktorému chodili pravidelne nakupovat’ víno. $\mathrm{V}$ čase socializmu obchody predávali víno, ale často to boli rôzne neidentifikovatel'né zmesky, napríklad MALOKARPATSKÉ ZLATO, JUŽNOSLOVENSKÝ VÝBER, KLÁŠTORNÉ ČERVENÉ, ktoré mali ku kvalitným vínam dost’ d’aleko. Niekedy sa však pomerne lacno dali kúpit’ aj kvalitné dovozové vína, napríklad z Mad’arska, Bulharska, Moldavska, Juhoslávie (Goldhammer: 1976). Okrem vína z hrozna bola na Slovensku tradičná a aj za éry socializmu rozšírená domácka výroba rôznych ovocných vín, napríklad ríbezlové, šípkové, trnkové, čučoriedkové, čerešňové... L'udia ich robili a pili na dedinách aj v mestách ako najlacnejšiu alternatívu alkoholického nápoja. Kupované ovocné dezertné víno, tzv. „čučo“, bolo lacným a oblúbeným nápojom mládeže a všetkých, ktorí mali hlboko do vrecka. Na oslavy, najmä na Silvestra, sa kupovali šumivé vína, chybne nazývané šampanské, ako HUBERT, VENUŠA, BELVEDER SEKT alebo kvalitnejší dovážaný sekt SOVJETSKOJE IGRISTOJE.

Po druhej svetovej vojne začala na Slovensku stúpat’ aj spotreba piva. K starším pivovarom začali pribúdat', najmä v 60. a 70. rokoch 20. storočia, nové vel'ké pivovary: Šariš, Gemer, Urpín, Zlatý bažant. 


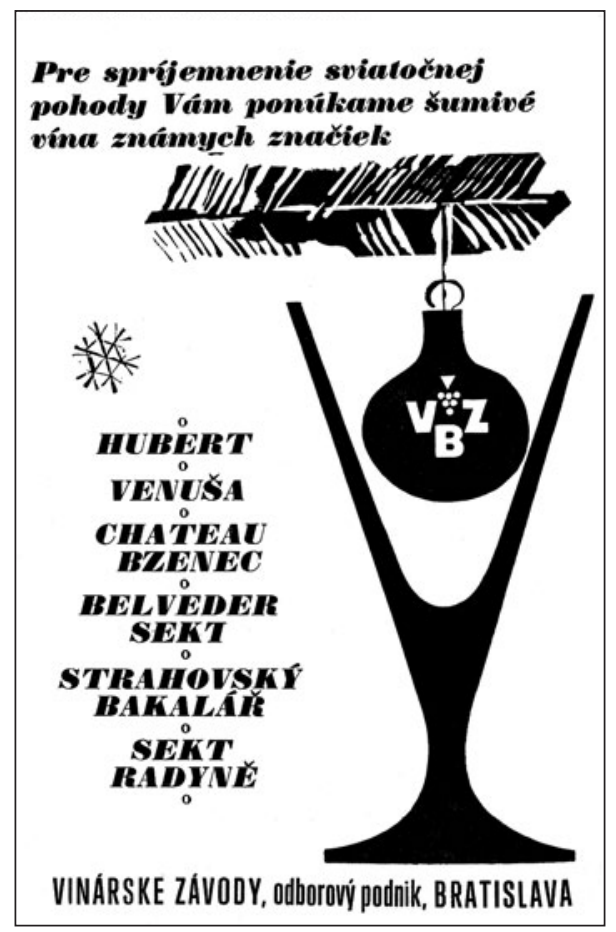

K najoblúbenejším pivám patrí dodnes ZLATÝ BAŽANT, ktorý už v roku 1971 plnil pivo do plechoviek a v 80. rokoch začal vyrábat’ aj prvé nealkoholické pivo PITO. K stúpajúcej spotrebe a oblube piva na Slovensku prispel najmä spoločný československý trh, ked’ sa sem dovážali české pivá, ako aj fakt, že množstvo Slovákov pracovalo $\mathrm{v}$ baniach, oceliarňach, továrňach a podobne $\mathrm{v}$ českých a moravských krajoch, kde sa naučili pivo pravidelne konzumovat'. Na domácu spotrebu sa pivo kupovalo v sklených flašiach v potravinárskych obchodoch alebo sa chodilo čapovat’ do krčahov do pohostinstiev.

V mnohých domácnostiach sa všetky nápoje pili z tzv. horčičiakov, čo boli sklenené dvojdecové poháre od horčice a hovorilo sa im 
„ruská Zuzana“. Na staniciach sa pivo zasa čapovalo do papierových navoskovaných pohárov.

V rámci kampane „Povedz alkoholu nie“ bol zavedený zákaz predaja alkoholu do 10.00 hodiny. Socialistická spoločnost’ predpokladala človeka nielen pracovitého, ale i triezveho. Alkohol brzdil upevňovanie a rozvoj socialistického spolužitia, spôsoboval spoločenské škody a narušoval výstavbu rozvinutej socialistickej spoločnosti. Bol spolu s imperialistami považovaný za nepriatel'a l'udstva (Šebo: 2010, 49).

Aj keby sa to nezdalo, ale k špecifikám socialistického stravovania patrili aj rôzne diéty. Odborníci na výživu síce neustále kritizovali západný spôsob konzumnej spoločnosti a diéty považovali za západný fenomén, postupne však museli pripustit', že tento problém sa dotýka aj socialistického spôsobu života Čechoslovákov. Nezdravé stravovacie návyky viedli $\mathrm{k}$ tomu, že u nás od polovice 50. rokov 20. storočia medzi populáciou narastala obezita. Každá druhá žena a každý tretí muž boli obézni. Štatistiky dokazujú, že medzi rokmi 1965 - 1981 spotreba tuku v strave neustále narastala. Preto od 70. rokov 20. storočia bola tematika správnej výživy a chudnutia vel'mi populárna a spájala sa najmä s menom Dr. Rajka Dolečka, ktorý mal v televízii program Nebezpečný svet kalórií, v ktorom l'udom v týchto otázkach radil. Napriek pomerne masívnej osvete, ako zracionalizovat’ stravu a schudnút', obezitu sa v spoločnosti nedarilo výrazne obmedzit'. Existovali aj týždenné pobyty na chudnutie, kde sa pomocou cvičenia a správnej výživy mali l'udia naučit', ako zdravo žit'. Medzi ženami kolovali často neuveritelné a "zaručené“ diéty na schudnutie, napríklad: hollywoodská mäsová, vajíčková, jogurtová, zemiaková, banánová, tvarohová a dokonca aj vínna, ked’ sa namiesto jedla pilo víno. Hlavným problémom týchto kurióznych diét bola jednostrannost', ktorá vyplývala z toho, že v obchodoch nebol dostatočný výber rôznorodých zdravých potravín, predovšetkým zeleniny a ovocia (www.ceskatelevize/porady/retro). S tým mali vel'ké tažkosti aj ludia na zdravotných diétach, ktoré im predpísali lekári, avšak zohnat' na ne adekvátne potraviny bol často problém. 
Z racionalizačných opatrení vo výžive socialistického človeka je zrejmé, že odborníkom išlo o zmenu stravovacích návykov najmä vidieckeho obyvatel'stva. Chceli odstránił’ stereotypy v jeho výžive, historicky podmienené formami súkromného rol'níckeho hospodárenia a z neho vyplývajúceho samozásobitel’stva potravinami, ktoré významne determinovalo kvalitu i kvantitu ich tradičnej stravy. Preto sa snažili o zníženie spotreby bravčovej slaniny a údeného mäsa, typickej pre vidiecke domácnosti, a o ich nahradenie čerstvým mäsom a rastlinnými tukmi alebo olejmi. Zároveň apelovali, aby sa v ich strave zvyšovala aj konzumácia masla a vajec. Tie totiž bývali určené u súkromných rol’níkov najmä na predaj. Na druhej strane sa z vidieckej stravy v časoch socializmu postupne vytrácali jej hodnotné prvky. Tmavý domáci chlieb nahradil biely chlieb a biele pečivo z pekární namiesto tradičného jednoduchého múčneho pečiva a koláčov, ktoré sa kedysi piekli len príležitostne v čase sviatkov, šírila sa konzumácia vysoko kalorických zákuskov a tort. Zo stravy postupne mizli aj d’alšie tradičné jedlá, napríklad zdravé obilninové a strukovinové kaše, ale aj tvaroh a bryndza, pretože boli často nedostatkovým tovarom. Problémy boli aj so zásobovaním obyvatel'stva zeleninou a ovocím napriek neustálemu zdôrazňovaniu jeho potreby vo výžive. Za najväčší nedostatok socialistickej racionalizácie výživy možno však považovat' niekol'konásobné prevýšenie spotreby cukru nad jeho výživovú potrebu, čo platilo tak pre vidiecke, ako aj mestské domácnosti. Realitu v stravovaní obyvatel'stva v rôznych etapách socializmu na Slovensku najlepšie dokumentujú dobové dietologické a etnografické výskumy, ktoré prinášajú spomienkami neskreslené fakty, a preto majú pre sledovanú problematiku nezastupitelnú výpovednú hodnotu. 


\section{VÝSLEDKY DIETOLOGICKÉHO VÝSKUMU}

Otázkami výživy obyvatel'stva na Slovensku v období socializmu sa zaoberali predovšetkým výskumníci Ústavu výživy l’udu v Bratislave. Mohli sa opriet’ o metodické postupy výskumu overené vo svete i v Československu, ktoré nepodliehali politickým tlakom tak silno ako napríklad výskum $\mathrm{v}$ humanitných disciplínach. Ich výsledky na makroúrovni napriek dobe vzniku sprostredkúvajú kvalitné a relevantné dobové informácie o stravovacích modeloch obyvatel'stva Slovenska, z ktorých môžeme získat' množstvo dôležitých poznatkov o sledovanej problematike.

Výsledky prvého celoslovenského výskumu po zmene spoločenského systému na Slovensku boli zhrnuté v knihe MUDr. Juraja Budlovského a jeho kolektívu pod názvom Stav výživy obyvatel'stva na Slovensku, ktorá vyšla v roku 1960. Práca je vyhodnotením výsledkov výskumov, ktoré sa konali v zime a na jar na prelome rokov 1955 a 1956. Výskum mal tri okruhy: dietetický, klinicko-biologický, ekonomický. Pri dietetickom výskume sa zistovali kvantitatívne a kvalitatívne ukazovatele stravovania - príjem hlavných výživových látok, spotreba rôznych potravín, vhodnost’ jedálnych lístkov, technológia príprava jedál. Realizoval sa sedemdňovým výskumom $\mathrm{v}$ rodinách. Klinicko-biochemický výskum sledoval somatický a zdravotný stav obyvatel'stva so zretel'om na tie znaky, ktoré sú najviac ovplyvňované výživou: hmotnost', výška, stav chrupu, úroveň hemoglobínu a pod. Tretím okruhom bol výskum ekonomických podmienok života obyvatel'stva, ktoré majú rozhodujúci vplyv na jeho stravovanie. Sledovali sa peňažné príjmy obyvatel'ov, výmera pol’nohospodárskej pôdy, živočíšna a rastlinná produkcia rol'níckych rodín, stav dopravy a zásobovania potravinami, krajové návyky i zlozvyky v stravovaní. Výskum sa realizoval 
v rodinách, obchodoch, úradoch a pomocou štatistických údajov. Pri výmere pol'nohospodárskej pôdy sa nehodnotili rolnícke rodiny socialistického sektora, pretože tá bola zhruba pol hektárom pôdy (tzv. záhumienka) na celom území Slovenska rovnaká. U samostatne hospodáriacich rol’níkov bol výskumný súbor rozdelený podla výmery pôdy na jednu rodinu: do 3 ha, $3-5$ ha, $5-10$ ha a nad 10 ha. U kovorol'níkov, kde bola výmera pôdy spravidla menšia, sa použilo rozdelenie do 1 ha a nad 1 ha (Budlovský: 1960, 22, 38).

Výskum sa uskutočnil na celom Slovensku, ktoré bolo vopred rozdelené na devät oblastí ${ }^{1}$ a v nich sa rovnomerne, podl'a počtu obyvatel'stva, vybralo 94 lokalít. Skúmané obce boli rozdelené do piatich kategórií: do 2000 obyvatel'ov, od 2000 do 5000 obyvatel'ov, od 5000 do 10000 obyvatel'ov, od 10000 do 20000 obyvatel’ov a obce nad 20000 obyvatel'ov. Na rozdiel od cieleného výberu vidieckych i mestských lokalít v daných oblastiach bol výber skúmaných rodín ponechaný na náhodu. Výskumom sa vyšetrilo 505 rodín s celkovým počtom 2771 osôb. Ako uvádza autor, „,...štruktúra rodín zúčastnených na výskume nezodpovedá celkovej sociálnej štruktúre obyvatel'stva na Slovensku. Pri opatrnom vyhodnotení a matematickej, najmä však logickej korekcii získaných výsledkov môžu sa previest’ do formy reprezentatíonej pre celý národ, aby mohli slúžit’ pre súčasnost’ i budúcnost' ako podklad, ako sa obyvatel'stvo Slovenska živilo v dobe výskumu..." (Budlovský: 1960, 47 - 57). Metodika cieleného výberu lokalít a náhodného výberu skúmaných rodín bola pri tomto výskume rovnaká ako napríklad pri podobnom výskume v Írsku a neprispôsobovala sa teda tendenčne novým politickým pomerom na Slovensku (O'Connor - Hourihane: 1950, 269). ${ }^{2}$

1 Bratislavská, západoslovenská pahorkatina, juhoslovenská nížina, juhoslovenská pahorkatina, stredoslovenská hornatá oblast', severoslovenská priemyselná oblast', severoslovenská hornatá oblast', východoslovenská nížina a východoslovenská pahorkatina.

2 Podobnou metodikou sa postupovalo aj pri etnografickom výskume v rokoch 1971 - 1975 pre Etnografický atlas Slovenska. 
Z výsledkov, ktoré priniesol výskum pod vedením J. Budlovského, možno vybrat' množstvo údajov, ktoré sú zaujímavé aj pre etnologický a sociologický diskurz o socialistickej realite v oblasti výživy. Relevantným zdrojom týchto poznatkov je v dietetickom segmente predovšetkým tá čast', ktorá analyzuje obsah jedálnych lístkov v skúmaných rodinách:

„...Zastúpenie rôznych jedál v jedálnom lístku na raňajky vykazuje po kvantitatívnej i kvalitatívnej stránke pozoruhodné rozdiely pri porovnaní väčších a menších obcí. Výdatnejšie (hutné) jedlá bez kávy, ako sú praženica s chlebom, chlieb so slaninou, údeninami, zemiaky čisté alebo s mliekom, či kapustou, polievky a omáčky podávané samostatne alebo s inými jedlami, kysel, pirohy, halušky, syry, vajcia a iné jedlá sa vyskytujú ovel'a častejšie na dedinách. So stúpajúcou vel'kost’ou obcí ich význam klesá a mnohé z nich sa vo väčších mestách wôbec neobjavili. Príčinou je snaha vidieckych gazdiniek podat' silnejšie raňajky pred namáhavou prácou na poli. S rastúcou vel'kost’ou obcí stúpa naopak podávanie bielej kávy, mlieka alebo kakaa s pečivom a chlebom. Na konzumovanie l’ahších raňajok v mestách vplýva spôsob zamestnania, zvyklost', jednoduchost' prípravy a podávanie desiatej. (...) U rolníkov socialistického sektora, raňajkám ktorých sú svojím zložením blizke aj raňajky dôchodcov, javí sa už značný posun $k$,mestskému' jedálnemu lístku, výrazný najmä u kovorol'níkov, ktorých ranný jedálny lístok je zhodný so skupinou t'ažko pracujúcich robotníkov. (...) Raňajky sú na celom slovenskom vidieku bez ohl'adu na úrodnost' kraja a majetnost' obyvatel'stva pestrejšie a výdatnejšie ako u mestského obyvatel'stva. Káva sa na vidieku konzumuje iba v menej majetných vrstvách, zatial' čo väčšina požíva hutné jedlá. (...) Inakšie je to u robotníkov, kde musíme častý výskyt málo výdatných raňajok hodnotit’ ako vážny nedostatok vo výžive. (...) Pokračujúca industrializácia s prílevom pracovných síl z vidieka do miest nás oprávňuje domnievat' sa, že aj na vidieku sa uplatňujú, aj ked’ čiastočne a pomaly, mestské zoyky pri príprave raňajok, ktoré nie sú primerané charakteru rol'níckej práce. (...) Je potrebné, aby sa širšie uplatnilo mlieko a mliečne výrobky, ktorých spotreba je všeobecne nízka. (...) V zastúpení jedál na raňajky sú rozdiely aj medzi jednotlivými oblast’ami Slovenska. Podávanie syrov, vajec, slaniny alebo údením s chle- 
bom a tekutinou je najčastejšie v južných polnohospodárskych oblastiach, najmenej časté v hornatých oblastiach severného a východného Slovenska. (...) Podávanie polievok s chlebom je najčastejšie v severoslovenskej priemyselnej oblasti (trenčiansky región). Pestrost’ou raňajok vyniká východoslovenská pahorkatina, kde je doteraz zachovaný vel'ký a zaujímavý sortiment typických jedál. Táto oblast’ je tiež najmenej dotknutá mestskými oplyomi a uchováva si tradičné stravovacie zvyklosti“ (Budlovský: 1960, 64 - 67).

Značné rozdiely v stravovaní rôznych sociálnych vrstiev boli zadokumentované aj pri analýze obedov a večerí. „....Konzumácia polievok bola častejšia na vidieku, ako v mestách. (...) Vidiečania z časových dôvodov varia na obed iba jedno hutné sýte jedlo vo väčšom množstve a stratu tekutín nahrádzajú podaním tekutejších pokrmov na večeru. Niekedy tu nahrádza polievka s výdatnou závarkou večeru.

$V$ mestách sa konzumovali častejšie mliečne, zeleninové, ovocné a hubové polievky, naproti tomu na vidieku zemiakové, strukovinové, obilninové a zapražené polievky. (...) Výskyt konzumácie mäsa má vzostupnú tendenciu s rastúcou vel'kostou obcí. Najviac výsekového mäsa sa podáva v mestečkách a menších mestách, kde sa často varí mäso v polievke. Na dedinách sa skôr varí údené mäso alebo hydina. (...) Dusené a pečené výsekové mäso sa podáva najviac v mestách nad 5000 obyvatelov. To isté sa týka pečenej hydiny, vyprážaného mäsa, vyprážanej hydiny a rýb. Guláše a paprikáše sa podávajú najčastejšie v malých mestách. (...) Na rozmanitost’ obedov značne vplývajú krajové zvyklosti: napríklad podávanie plnenej papriky na južnom Slovensku, plnenej kapusty na východnom Slovensku. Údeniny sa vyskytujú najviac vo vel'kých mestách nad 20000 obyvatel'ov. Spolu s chlebom nahrádzajú celú večeru, a to aj na dedinách, ak sú zdroje z domácej zakál'ačky. (...) Vnútornosti sú vel'mi málo zastúpené najmä v obciach pod 10000 obyvatel'ov. Pomerne málo sa podávajú ryby a hydina. (...) Varené výsekové mäso najčastejšie konzumujú kovorolníci a robotníci. Varené údené mäso bolo na stole najčastejšie u rol'níkov socialistického sektora, ale pomerne často aj u robotníkov a kovorol'níkov. Údené mäso bolo najčastejšie $z$ domácich zdrojov. (...) Celkovo možno konštatovat', že výskyt mäsa v jedálnych lístkoch dosial' neuspokojuje ani množstvom, ani pestrostou prípravy. Týka sa to opät' vidieka, kde je pestrost' a rozmanitost' mäsa malá 
a obmedzuje sa väčšinou na najjednoduchšie úpravy. (...) Obedy alebo večere často tvorili prívarky alebo omáčky podávané so zemiakmi, knedlami alebo chlebom. Najčastejšie to boli paradajkové alebo chrenové omáčky a kapustový prívarok, ktorý v severoslovenských oblastiach tvoril so zemiakmi často aj celodenné jedlo. Strukovinové prívarky boli preferované najmä v stredoslovenskej oblasti. (...) Najčastejšou prílohou k mäsu sú na celom Slovensku zemiaky, menej cestoviny alebo ryža. (...) Výskyt bezmäsitých múčnych jedál vykazuje vzostupnú tendenciu od vel'kých miest smerom $k$ menším mestám a najmä dedinám... Je to $z$ toho dôvodu, že sú sýte a $v$ dobe pol'ných prác sa l’ahko prenášajú a často spolu s nápojom sú hlavným jedlom. Najoblúbenejšími cestovinami sú rezance, fliačky a halušky. Konzumácia halušiek prevláda na dedinách najčastejšie vo východoslovenskej nížine a severoslovenskej horskej oblasti, kde sú halušky s kapustou, tvarohom alebo bryndzou typickými krajovými jedlami. Kysnuté pečené cestá sa vyskytli najviac v západoslovenskej pahorkatine a juhoslovenskej nížine, kysnuté varené cestá v bratislavskej a severoslovenskej priemyselnej oblasti a kysnuté vyprážané cestá v západoslovenskej pahorkatine, juhoslovenskej a východoslovenskej nížine. (...) Celkovo možno konštatovat’ značný výskyt múčnych jedál, najmä z rezancového cesta, halušiek a múčno-zemiakových jedál pri obedoch i večerách. (...) Múčniky ako súčast' predovšetkým nedelného obeda sa konzumovali najmä v mestečkách a menších mestách, vo všetkých sociálnych kategóriách rodín s výnimkou samostatne hospodáriacich rolníkov. Dominovali kysnuté múčniky nad jemnejšími piškótovými a inými krehkými cestami. (...) V tejto oblasti je potrebné zvýšit’ vedomosti gazdiniek v cukrárenskom umení a propagovat' význam múčnikov z hl'adiska výživnosti a chutnosti jedál, so zameraním na druhy, ktorých príprava je menej namáhavá. (...) Výskyt nápojov na obedy je častejší na dedinách, ako v mestách. Z nedostatku času a najmä zo zaužívaných zvykov podávajú sa na dedinách pomerne často nekompletné obedy, a to v podobe zemiakov s mliekom. $V$ chudobnejších rodinách sa mlieko nahradzuje vodou zo sušeného ovocia alebo nálevom z kvasenej kapusty. Z nápojov podávaných k obedu sa najviac vyskytlo mlieko a čaj, menej biela káva. Najčastejším nápojom $k$ večeri bol čaj, ktorého výskyt bol však o 100 \% vyšší $v$ mestách, ako na dedinách, kde sa podávalo často aj mlieko a biela káva. 
Je zaujímavé, že mlieko sa konzumuje na dedinách skôr na večeru, ako na raňajky, teda opačne ako v mestách... Pivo pri večeri sa konzumovalo najmä na väčších dedinách a v stredne vel'kých mestách. (...) Vo výskyte nápojov boli značné regionálne rozdiely. Najčastejšie tvoria súčast' obeda a večere $v$ severoslovenských regiónoch a vo východoslovenskej pahorkatine, najmenej v južných oblastiach Slovenska. (...) Medzi nápojmi je zarážajúci nedostatok malinoviek a ovocných štiav. Aj ked’ bol výskyt čaju najvyšší spomedzi všetkých nápojov, dávajú sa doňho namiesto ovocných štiav a sirupov rôzne liehoviny, ktoré majú slúžit’ na zlepšenie chuti. Možnost' doplnenia ochranných látok, najmä vitamínu $C$, ktorých je v strave nedostatok, nápojmi, ostáva nevyužitá (Budlovský: 1960, 64 - 86).

Z detailnej analýzy jedálnych lístkov, ktoré uvádza J. Budlovský, možno sumarizovat' nasledujúce fakty. Obedy a večere, najmä však obedy, sa v mestách a na vidieku podstatne lísili po kvalitatívnej stránke. Obedy v mestách mali spravidla viac chodov, počas týždňa sa vystriedali rôzne polievky, mäsá, prívarky a múčne jedlá. Na vidieku sa určité, najmä typické regionálne jedlá opakovali viackrát v týždni, niekedy dokonca po celý týždeň s výnimkou nedele. Tento konzumný stereotyp bol zásadným rozdielom medzi mestom a vidiekom a platil pre celé Slovensko. $V$ mestách sa jedlo menej, ale častejšie, jedálne lístky boli pestrejšie a vyváženejšie, dbalo sa na pravidelnost’ v stravovaní a príprave jedál sa venovala väčšia pozornost'. Najväčším nedostatkom stravovania na vidieku, najmä v severných horských oblastiach, bol obmedzený počet základných potravín: obilniny, zemiaky, kyslá kapusta a mlieko, teda potravín (s výnimkou mlieka) obsahujúcich sacharidy, ktoré pri nízkej konzumácii mäsa a vajec boli z hl'adiska bielkovín poddimenzované. Z hl'adiska živín bola táto strava značne nerovnovážna. Tieto výsledky sú vel'mi podobné tým, ktoré sa robili v tridsiatych rokoch 20. storočia (Pelc: 1940). To znamená, že k pozitívnemu obratu v kvalite stravovania vidieckeho obyvatel'stva nedošlo ani po siedmich rokoch budovania socializmu.

Zaujímavé dobové informácie možno nájst’ v knihe J. Budlovského tiež v časti analyzujúcej ekonomické faktory výživy obyva- 
tel'stva, najmä tie, ktoré komentujú distribúciu potravín. Tieto výsledky boli podopreté zisteniami v 383 distribučných zariadeniach: v 100 predajniach potravín, 88 mäsiarstvach, 78 predajniach mlieka a mliečnych výrobkov, 47 predajniach zeleniny a ovocia a 70 lekárňach.

Mlieko a mliečne výrobky sa predávali v prevažnej časti skúmaných obcí. Doprava, ako aj stav zásob egalizovaného mlieka bol uspokojivý, až na niektoré vidiecke sídla, kde sa mlieko nepredávalo a l’udia tam boli odkázaní na vlastnú produkciu mlieka. (...) Aj distribúcia konzervovaného mlieka bola uspokojivá. Avšak distribúcia sušeného kojeneckého mlieka bola nepravidelná alebo nedostatočná takmer v polovici navštívených lekární. (...) Distribúcia smotany, tvarohu, bryndze vykazovala početné nedostatky $v$ stave zásob $i$ v pravidelnosti jeho dopravy do predajní. Stav zásob masla bol dostatočný a dopyt spotrebitel'ov uspokojivý... Podobne uspokojivá bola distribúcia vajec. (...) Avšak zásobovanie predajní čerstvým výsekovým mäsom možno charakterizovat’ ako neuspokojivé. Týkalo sa to najmä bravčového mäsa, ale i hovädzieho a tel'acieho mäsa. Vo väčšine obcí bola doprava mäsa nedostatočná a nie dost’ častá. Týkalo sa to najmä vidieka, kde nebola ani dostatočne hustá siet’ predajní s mäsom... St’ažnosti na nedostatočnú distribúciu bravčového a hovädzieho mäsa patrili $k$ najčastejším. Na rozdiel od čerstvého mäsa bol vyhovujúci až nadmerný stav zásob mrazeného mäsa. Jeho neobl'úbenost’ medzi konzumentmi bola spôsobená nedôverou $k$ takto spracovanému mäsu a nedostatočným vybavením domácností chladiacimi spotrebičmi. (...) Pri hydine a zverine bol stav zásob nedostatočný a nedostatky sa týkali viac vidieka, ako mesta. (...) Pri mrazených rybách bol stav zásob a dopytu vyrovnaný, nie však pri kyslých a údených rybách, o ktoré bol na vidieku vä̌čsí záujem ako v mestách. (Dá sa predpokladat, že to bolo najmä v čase pôstov)... V mestách sa viacej konzumovali konzervované ryby v oleji, rybie šaláty i čerstvé ryby, pretože to umožňovalo technické vybavenie predajní. (...) Distribúcia vnútorností bola vyhovujúca v mestách, menej na vidieku. Neuspokojivý dopyt bol najmä pri pečeni. (...) Stav zásob rôznych údenín bol v prevažnej miere na predajniach uspokojivý. Týka sa to najmä obyčajnej salámy a klobásy, najmenej troan- 
livej salámy, párkov a jaterníc... V niektorých prípadoch sme zistili, že prísun údenárskych výrobkov do predajní pokračoval, aj ked’ nebol dostatočný dopyt a predajne si tento tovar neobjednali. (...) Nevel'mi uspokojivá situácia bola pri masti a slanine, kde boli markantné rozdiely medzi predajňami v mestách a na vidieku, pretože tam po nich nebol dostatočný dopyt. (Domácnosti na vidieku si dokázali zo zabijačiek tieto tuky zabezpečit’ samé.) (...) Lepšie bolo zásobovanie predajní rastlinnými tukmi, avšak ich spotreba v strave má pomerne malú úlohu...

...Stav zásob, ako aj dopyt po cukre bol na celom Slovensku vyhovujúci a vyvážený. Zásobovanie cukrom bolo zo všetkým potravín najlepšie. (...) Múka bola dodávaná do predajní pravidelne a vo vyhovujúcom množstve, $v$ mestách $i$ na dedinách. Horšia bola situácia v distribúcii chleba. Nedostatky sa vyskytli v obciach do 2000 obyvatel'ov a príčinou bola doprava. Záujem o biele pečivo bol pomerne vysoký aj na dedinách. Vo vidieckych predajniach boli nadmerné zásoby niektorých druhov trvanlivého pečiva s vy̌šsou cenou. Distribúcia cestovín bola uspokojivá, niekde však nebolo dostat’ napríklad nit’ovky do polievok. Distribúcia ryže bola vyhovujúca...

...Stav zásob strukovín bol uspokojivý, na vidieku pre nezáujem až nadmerný. (...) Distribúcia zemiakov mala vo väčšine prípadov kolísavý charakter. (...) Zretel'né boli sezónne rozdiely. $V$ zimných mesiacoch bol dopyt častejšie uspokojený ako v jarných mesiacoch a týkal sa tak miest, ako i vidieka. (...) Podobne ako pri zemiakoch ani pri zelenine nemožno charakterizovat' distribúciu ako uspokojivú, to sa týka viac vidieka ako miest. Doprava je často nepravidelná a nedostatočná. (...) Neuspokojivý stav bol dokonca aj pri sudovej kapuste. (...) V nedostatočnom množstve sa vyskytovali aj produkty zo zeleniny, ako nakladané sladkokyslé uhorky, lečo, paradajkový pretlak. Mrazená zelenina sa predávala najviac vo väčších mestách, kde už mali l’udia chladiace zariadenia. (...) Zásobovanie tuzemským ovocím bolo v období výskumu nedostatočné, najhoršie zo všetkých potravín. Z južného ovocia bol stav zásob uspokojivý pri citrónoch $43 \%$, pri pomarančoch v $35 \%$ predajni, boli však zretelné regionálne rozdiely. Neuspokojivý dopyt bol najmä v Bratislave a naopak $v$ malých obciach boli zasa nadmerné zásoby južného ovocia, kde sa pre ich 


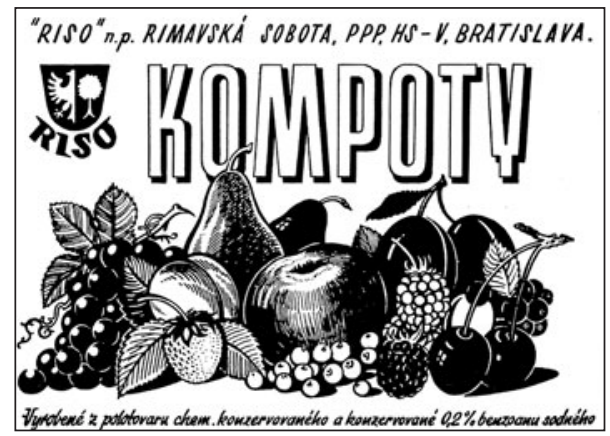

vysokú cenu nekupovali. Z rovnakých dôvodov sa tam nemínali drahšie druhy kompótov. (...) Siet’ predajní zeleniny a ovocia nie je dostatočne hustá, takže určitá čast’ obyvatel’stva nemá prístup k zásobeniu sa týmito biologicky dôležitými potravinami“ (Budlovský: 1960, 288 - 297).

Z analýzy o ekonomickej podmienenosti výživy obyvatel'stva vyplýva niekol'ko závažných faktov. Ide najmä o konštatovania dotýkajúce sa produkcie a distribúcie potravín, ktorá mala významný vplyv na kvalitu a vyváženost' stravy obyvatel’stva. V polovici 50. rokov 20. storočia na Slovensku išlo najmä o nedostatočnú distribúciu niektorých základných potravín: smotany, tvarohu, čerstvého mäsa, ovocia a zeleniny. Výroba a distribúcia nebola schopná zabezpečit’ ani výživu pre dojčatá v podobe sušeného mlieka. Vážnym nedostatkom bola aj nevyváženost' distribúcie medzi mestom a vidiekom, ked’ sa niektoré základné potraviny vôbec nedostávali alebo len sporadicky dostávali do dedinských predajní (napríklad chlieb). Ako vieme aj z etnografických výskumov, táto situácia mala trvalejší charakter, ktorý pokračoval aj v nasledujúcich rokoch. Okrem nedostatočných, a často aj nevhodných, dodávok potravín na vidieku pôsobil aj d’alší faktor - nedostatočná siet’ predajní potravín. Ďalším negatívnym faktorom bola potravinová sezónnost', ktorú dobová distribúcia nebola schopná vyriešit’ k spokojnosti zákazníkov, napríklad dostatok rýb v čase pôstov, dostatok masla, tvarohu, vajec, mäsa, ovocia v čase sviatkov a pod. Na druhej strane došlo k výraz- 
nému nárastu spotreby cukru, čo sa síce kvalifikovalo ako pozitívny výsledok, avšak z pohl'adu racionálnej a zdravej výživy to bol skôr negatívny výsledok s dlhodobými zdravotnými následkami pre slovenskú populáciu.

Je evidentné, že výskum výživy slovenského obyvatel'stva v rokoch 1955 - 1956 nepriniesol príliš optimistické výsledky, skôr naopak. Kniha J. Budlovského v závere priniesla preto aj návrhy, ako túto situáciu zlepšit:: „...Polnohospodárska prvovýroba by mala zoýšit výrobu živočíšnych potravín, zeleniny a ovocia. (...) Nedostatky sa týkajú najmä chovu hovädzieho dobytka, čo sa odráža na nízkej spotrebe masla, syrov, smotany, ale aj bravov. (...) Z hl'adiska racionalizácie výživy l'udu majú prooradý význam všetky otázky súvisiace so zvýšením produkcie zeleniny a ovocia. (...) Okrem kvantitatívnej stránky sa v dobe po X. zjazde KSČ venuje zoýšená pozornost’ aj kvalitatívnej stránke výži-

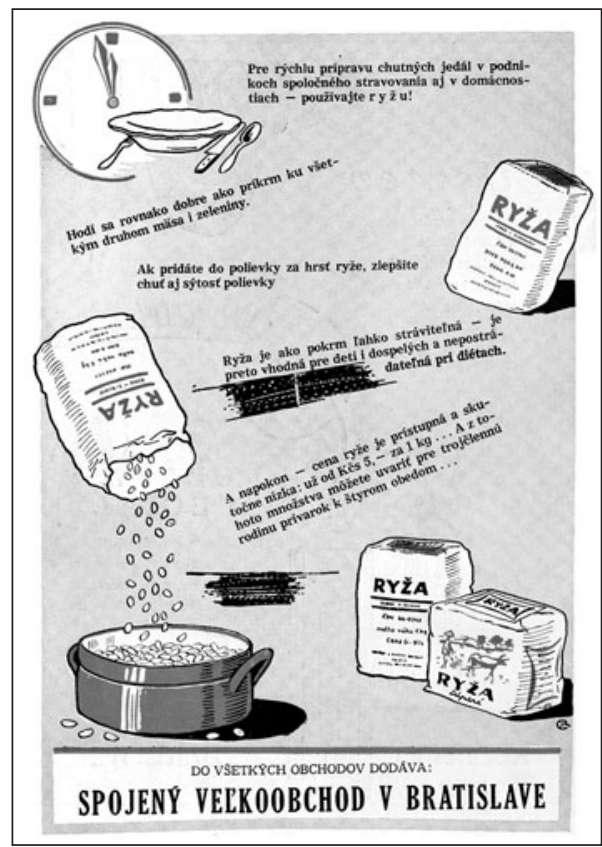




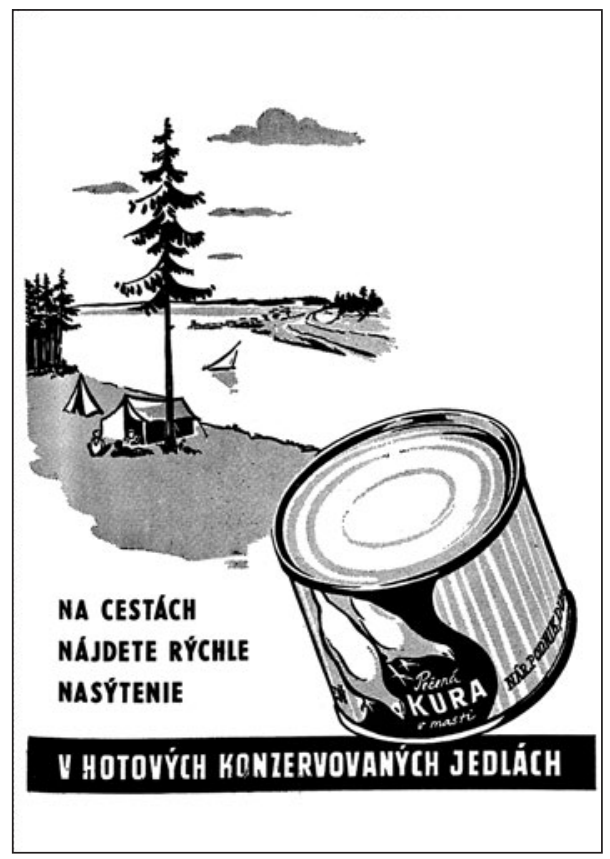

vy, najmä vzhl’adom na zvýšenie obsahu výživových látok v potravinách. Vzhl'adom na vel'ký význam zemiakov pre výživu l'udu by bolo účelné, aby sa pol'nohospodársky výskum zaoberal možnost'ou dopestovat' vhodné druhy zemiakov s vyšším obsahom vitamínu $C$ a askorbigénu, ako aj vhodné druhy zeleniny s vyšším obsahom vitamínu C a karoténov. (...) Potravinársky priemysel by mal zoýšit' produkciu nedostatkových potravín. Neuspokojivý dopyt sa týkal: mäsových konzerv vo vlastnej št’ave, paštík v menšom balení, troanlivých salám, topených syrov, tvarohu, kyslých rýb, sušených mliečnych preparátov, detských piškót, ovocných sirupov, kompótov, leča, sladkokyslých uhoriek, sušených sliviek, mrazenej zeleniny, kvasníc, ruského čaju, jemných korenín a čierneho korenia. (...) Neuspokojivý dopyt po týchto potravinách sa týkal vel'kej časti skúmanej populácie, najmä však na vidieku. (...) Uvedené nedostatky sa týkajú aj distribúcie potravín, ktorá vykazovala časté poruchy. (...) Potravinársky priemysel by 
sa mal zamerat' na výrobu mäsových polotovarov (karbonátky, rezne), mäsových konzerv, nátierok na chlieb, zeleninových konzerv a zahustených polievok v konzervách $v$ tekutom stave. (...) Je žiaduce rozširit’ spotrebu mrazenej zeleniny a ovocia aj do vidieckych oblastí, čo sa dá dosiahnut' len dobudovaním siete predajní a ich vybavením hlbokomraziacimi pultmi. Distribúcia by mala odstránit’ najčastejšie poruchy v zásobovaní pri mliečnych výrobkoch, čerstvom mäse, sušenom mlieku, zelenine. (...) Dodávky čerstvého mäsa súvisia aj so zdokonalením technického zariadenia najmä vidieckych predajní (chladiace komory, v niektorých predajniach chýbajú aj chladničky). (...) Mal by sa rozšírit’ predaj celozrnného chleba. (...) Na výživu obyvatel'stva odl'ahlých obcí mala nepriaznivý vplyv vel'ká vzdialenost' od potravinových predajní. (...) Pri rozširovaní nových potravín je nevyhnutná široká odborná propagácia. (...) Finančná stránka výživy by sa mala uberat' správnou cenovou politikou, ktorá môže do značnej miery regulovat' spotrebu potravín podl'a vedeckých poznatkov o správnej výžive. (...) K zlepšeniu výživy by prispela výroba lacných l'udových typov chladničiek do domácností. (...) Organizácia stravovania by sa mala zamerat' na formy hromadného stravovania. Týka sa to najmä vidieckych detí počas pol'nohospodárskych prác, ktoré sú ponechávané bez dozoru a teplej stravy, niekedy aj wôbec bez stravy až do večera. Bolo by potrebné zriadit' pri školách počas týchto prác kuchyne, kde by sa deti stravovali. (...) Je nevyhnutné uvažovat' o možnostiach spoločného stravovania pol'nohospodárskych, lesných a iných robotníkov, ktorí sa zatial' stravujú nepravidelne. (...) Zdravotno-osvetové opatrenia sú najlepšími prostriedkami vytvárajúcimi predpoklady pre zlepšenie výživy l'udu. (...) Postupná prevýchova ludu za účelom osvojenia si teoretických znalostí o správnej výžive a ich praktického uplatňovania musí byt’ systematická a začat' u školskej mládeže. (...) Školenie podobného charakteru bolo by potrebné aj pre gazdiné z vidieka, čím by sa tam stravovanie mohlo zlepšit’. Najlepším prostriedkom na dosiahnutie tohto ciel'a je usporiadanie kurzov správnej výživy a varenia na dedinách. (...) Jednotvárnost’ stravy na vidieku je podmienená najmä nedostatočnou znalostou varenia. (...) Nesprávnu výživu sprevádza slabá kultúra stolovania (jedenie celej rodiny z jednej misy), bývania a pod." (Budlovský: 1960, 313 - 323). 
Po tejto vel'mi kritickej a pravdepodobne aj reálnej analýze úrovne stravovacích modelov obyvatel'stva Slovenska v polovici pätdesiatych rokov 20. storočia sa v závere práce ponúka vel'mi stručný recept, ako situáciu socialistického človeka zlepšit: , „...Najúčinnejším prostriedkom zvyšovania hmotnej i kultúrnej úrovne vidieckeho obyvatelstva v súčasnej dobe je kolektivizácia vidieka, ktorá je sprevádzaná, ako ukazujú výsledky nášho výskumu, aj zlepšovaním výživy l’udu. Preto je úsilie o kolektivizáciu vidieka súčasne úsilím o zlepšenie výživy obyvatel'stva. (...) Život na vidieku sa však mení rýchlejšie ako stravovacie zvyklosti. (...) Vyrovnanie rozdielov medzi mestom a vidiekom aj na poli výživy je dlhodobou úlohou..." A potom nasleduje "povinná jazda“ každého dobového vedeckého či odborného diela: „...Vel'ká pozornost', ktorú venuje strana a vláda otázkam polnohospodárstva, ako aj iným otázkam súvisiacim s problematikou výživy, je však zárukou toho, že sa už v blízkej dobe vytvoria predpoklady pre prenikavé zlepšenie výživy nášho obyvatel'stva, a tým aj zoýšenie práceschopnosti, obranyschopnosti a dížky života (Budlovský: 1960, 323 - 325).

Ani tieto tendenčné citáty v nijakom prípade neznižujú odbornú úroveň rozsiahlej a viacročnej výskumnej úlohy. Je jasné, že autor musel nejakým spôsobom vyjst’ v ústrety dobe, ktorá propagovala kolektivizáciu pol’nohospodárstva a politiku budovania socialistického štátu ako všelieku na zvýšenie životnej úrovne l'udí, a je dost' možné, že tomu naozaj veril, tak ako mnohí ludia tej doby. Nič to však nemení na fakte, že kniha J. Budlovského, v ktorej sú uverejnené výsledky výskumu v čase prvej dekády budovania socializmu na Slovensku, nám vytvorila reálny obraz o stave stravovania l'udí v tomto období.

J. Budlovský sa nad’alej systematicky venoval výskumu výživy obyvatel'stva Slovenska a pravidelne prinášal svoje zistenia. V roku 1980, teda s odstupom štvrt'storočia od prvého výskumu v socialistickom zriadení, vo svojej správe konštatoval: „...Podrobnejšou analýzou aktuálnej situácie v spotrebe rozličných potravín zistujeme početné javy a trendy, ktoré sú v nesúlade alebo v protiklade s racionalizáciou výživy v zmysle skutočných potrieb civilizačne vyspelej spoločnosti. 
$V$ spotrebe mäsa pretrváva nepomer medzi bravčovým a hovädzím mäsom. Spolu s prevahou konzumu tučného mäsa nad chudým prispieva skrytý tuk z týchto zdrojov $k$ energetickej nadmernosti potravy. Pozitívnym javom je vzostup spotreby hydiny, spotreba čerstvých rýb je dosial' nedostatočná. Nevyhovuje celková štruktúra živočíšnych bielkovín, stúpa spotreba mäsa a vajec na úkor mlieka a mliečnych výrobkov. Spotreba proých sa znásobila niekol'kokrát, spotreba druhých sa nelísi od predvojnovej úrovne, pri plnohodnotnom mlieku, je dokonca nižšia. Pri mliečnych výrobkoch ich podstatnú čast' tvoria tučné a príliš slané syry. Spotreba tvarohu nedosahuje ani predvojnovú úroveň, pomerne nízka je i spotreba kysnutých mliečnych výrobkov. (...) Aj nízka spotreba jedlých olejov s vysokým obsahom esenciálnych mastných kyselín patrí $k$ závažným problémom súčasnej produkcie a spotreby. (...) Proti predvojnovým rokom stúpla spotreba cukru dvojnásobne a prevyšuje odporúčanú dávku viac ako o štvrtinu. (...) To isté platí pre trend spotreby alkoholických nápojov. (...) Svoju vysokú spotrebu si udržali aj obilniny a múčne výrobky. Prevláda pšeničná múka nad ražnou a najoýživnejšie ovsené vločky sa uplatňujú minimálne. Chlieb s vysoko vymletej celozrnnej múky ešte nemá primeraný podiel v celkovej spotrebe. (...) Velimi nízka je spotreba strukovín. (...) Spotreby zemiakov a zeleniny sú pomerne vyhovujúce, pri zelenine nie dostatočná diverzifikácia sortimentu. Menej uspokojivá je situácia v spotrebe ovocia, ktorá dosahuje len 60 \% odporúčanej dávky. (...) Takto je na Slovensku krytá polovica celkového energetického príjmu len dvoma potravinovými skupinami-mäsom a obilninami-, čo v podstatnej miere prispieva $k$ pretrvávaniu jednotvárnosti národnej stravy. (...) $\mathrm{Z}$ uvedenej analýzy spotreby potravy vyplýva, že adaptácia na zmeny životných podmienok a nimi podmienených výživových potrieb obyvatel'stva je u nás napriek značným zmenám neadekvátna. Pretroávajúce alebo nové problémy v kvalite a kvantite potravy, spotrebných zvyklostiach a v celkovom režime výživy nachádzajú svoj odraz v zdravotnom stave obyvatelstva..." (Budlovský: 1980, 269 - 270). 
Z tejto prevažne kritickej analýzy stavu výživy po viac ako dvoch dekádach budovania socializmu jednoznačne vyplýva, že zmena v myslení a návykoch l'udí napriek masívnej politicko-osvetovej práci tak rýchlo, ako si to predstavovali ideológovia a vedci na začiatku budovania socializmu, nenastala. Naopak, v oblasti výživy pribudli nové problémy, napr. nadbytočná spotreba tukov, cukru a alkoholu, s čím sa slovenská spoločnost’ borí ešte aj v súčasnosti. 


\section{VÝSLEDKY ETNOGRAFICKÉHO VÝSKUMU}

Na nové politické pomery v Československu reagovala aj súdobá etnografia. Je celkom pochopitelné, že $\mathrm{v}$ takom krátkom čase, v akom sa zmena politiky a s ňou spojené názory na výskum kultúry udiali, obrátila sa na inšpiračné zdroje sovietskej etnografie. V roku 1952 boli publikované pomerne rozsiahle materiály prevzaté a preložené z časopisu Sovietska etnografia. Prvý bol od autora N. J. Vorobjova „Program pre sbieranie materiálu na skúmanie súčasného spôsobu života kolchoznej dediny a dejín formovania u národností stredného Povolžia" (Národopisný sborník XI: 1952, 19 - 58), po ňom aj d’alšie, ktoré sa vyjadrovali k výsledkom diskusie sovietskych etnografov na tému výskumu súčasného spôsobu života v socialistickej spoločnosti (Český lid: 39, 1952 a nasledujúce ročníky).

Prijatie marxizmu-leninizmu, novej vedeckej teórie, ktorá bola v tom čase výlučnou a jedinou správnou a ktorú presadzovala politická moc od začiatku 50. rokov 20. storočia, sa pre etnografov na Slovensku stalo nielen vedeckou úlohou, ale stratégiou prežitia. V situácii, ked’ bola ohrozená samotná existencia disciplíny, navrhol Dr. Ján Mjartan niekol'ko projektov, ktoré sa pokúsili pracovat' metódou historického a dialektického materializmu. Prvou z týchto úloh bol stanovený výskum družstevnej dediny (Kiliánová - Popelková: 2010, 419).

Od 1. do 15. septembra roku 1952 sa uskutočnil prvý kolektívny terénny výskum družstevnej dediny, metodicky inšpirovaný sovietskou praxou, o ktorom podal písomnú správu jeho vedúci J. Mjartan v Slovenskom národopise (SN: 1953, 253 - 261). Vo svojej správe uvádza, že ako základ si zobrali návod na výskum a dotazník N. J. Vorobjova s dodatkom, že „hned’ sme si boli vedomí, že pre naše pomery nebude v každom ohl'ade vyhovujúci už pre ten podstatný rozdiel, že so- 
vietska etnografia skúma l’udovú kultúru na pokročilej kolchoznej dedine, kde je už socializmus zakotvený a kde sa už robia prípravy na prechod ku komunizmu, kým u nás sa má skúmat' l’udová kultúra v začiatkoch jej prechodu k socializmu."

Bolo stanovených 12 výskumných okruhov a ich personálne obsadenie. ${ }^{3}$ Za objekt výskumu bola vybratá obec Závadka nad Hronom. To preto, že ako jediná obec na Horehroní mala v tom čase JRD III. typu, avšak nebola to čisto rol’nícka dedina, pretože v obci bol priemyselný podnik a Štátna lesná správa, kde miestni občania tiež pracovali. JRD v Závadke bolo založené v roku 1950, k „rozoraniu medzí" - sceleniu pozemkov došlo v roku 1951. V čase výskumu pracovalo družstvo na výmere necelých 1000 ha pôdy a mimo JRD zostalo 44 súkromných hospodárstiev s výmerou okolo 250 ha, ktorým bola pridelená pôda v okrajových častiach chotára.

K sledovanej téme, ktorou bola možnost' získavania potravín a foriem stravovania obyvatel'stva, sú v správe len kusé informácie: „Z pol’nohospodárskych plodín sa pestujú zemiaky, ovos, raž, jačmeň, hrach. (...) V tom na JRD nenastali (oproti minulosti) žiadne zmeny. (...) Pestovanie zeleniny je tu teraz neznáme. JRD sa mu nevenuje a individuálne pestovanie prestalo po otvorení predajne Zelovoc v roku 1951. (...) K sústredeniu dobytka $v$ JRD od jednotlivých členov ešte nedošlo pre nedostatok hospodárskych budov a pre zlú politiku vedenia JRD. (...) Pre nové stavby družstevníkov je nezmenená obytná čast' domu, izba, kuchyňa a komora. $V$ kuchyni pod šporákom aj v novostavbách je pec na pečenie chleba, hoci $v$ obci je pekáreň a chlieb sa už doma nepečie. Ponechanie pece sa odôvod-

3 1. Polnohospodárstvo, družstevné kádre a inventár a družstevné hospodárenie (Podolák); 2. Živočíšna výroba a dopravné prostriedky (Bednárik); 3. Lesníctvo a spracovanie dreva (Demčiková); 4. Domáce zamestnanie a l'udové remeslá (Plicková); 5. Dedina a príbytky (Mjartan); 6. Odev, obuv a prikrývka hlavy (Brychtová); 7. Ludová strava a nápoje (Markuš); 8. Spoločenské a rodinné pomery, triedny boj na dedine (Melicherčík); 9 . Zvyky rodinné a ročné, povery (Gašparíková); 10. Kultúra, osveta, prozaická tvorivost' (Barabášová); 11. Ludová múdrost', výtvarná umelecká tvorivost’, výskum Cigánov (Čajanková); 12. L'udové hry (Ježová); 13. Hudobný folklór (Stankovičová); 14. Ludové piesne (Poloczek). 
ňuje najmä tým, že na sviatky treba piect’ koláče. (...) Novšie sa vybudovalo aj niekol'ko murovaných štvorcových stavieb so zvýšeným prízemím a s vaškuchyňou či pionicou pod ním..."

Na záver správy J. Mjartan konštatoval: „Vo výskume je potrebné pokračovat' dvojakým smerom: prehíbit’ výskum v Závadke historicky, čiže podat' genézu a historický vývin javov, ktoré sme zistili v dnešnom časovom priereze. (...) Ďalej bude treba rozšírit’ výskumy aj horizontálne, čiže rozšírit' ich aj na ostatné obce Horehronia, podat' profil l'udovej kultúry celej tejto oblasti a zároveň ukázat', ako sa v starých formách objavuje nový obsah, ako vznikajú nové formy a rozvíja sa socialistická kultúra" (Mjartan: 1953, 253 - 262).

Skúsenosti z tohto výskumu poslúžili na rozšírenie projektu o skúmanie d’alších dvoch „vzorových“ družstevných dedín Láb a Vel'ké Zálužice, jednej na západnom, druhej na východnom konci krajiny. Výsledky z týchto výskumov sumarizoval v roku 1955 v Slovenskom národopise Ján Podolák, ktorý pracoval na projekte ako asistent výskumu. V správe konštatuje: „Pri prvom výskume družstevnej dediny v roku 1952, konanom bez predbežných skúseností v hl’adaní a riešení tejto novej problematiky, dopustili sme sa vážnej chyby, že sme nevedeli dostatočne rozlišovat' medzi výskumom výrobných procesov družstva a medzi výskumom vplyvu týchto najdôležitejších faktorov na zmeny v spôsobe života družstevníkov. Príčina tejto našej metodickej chyby spočívala v tom, že $k$ výskumu nového objektu sme pristupovali starým spôsobom. Medzi štúdiom ekonomických otázok družsteonej dediny a štúdiom ,l'udového rol'níčenia' v období kapitalizmu je zásadný rozdiel. (...) Avšak v neskorších výskumoch sme sa už orientovali na zmeny organizácie práce a z toho vyplývajúcej zmeny spôsobu života, prekonajúc tak metodické problémy, ekonomizmus a štatistický postup', ktorým sa v začiatkoch nevyhli ani sovietski kolegovia. (...) Pri štúdiu každého javu v spôsobe l’udového života a jeho sociálnych a materiálnych základov sa dôsledne pridržiavame metódy historizmu. $V$ tomto je základný a principiálny rozdiel medzi pozitivistickou metódou buržoáznej etnografie a metódou pokrokovej etnografie."

Z tejto správy sa dozvedáme už detailnejšie informácie o súdo- 
bom stravovaní, ktorého výskumom bol poverený, rovnako ako v Závadke, Michal Markuš. Konštatuje sa v nej: „...Na Horehroní sa prejavil najoäčš́ zlom v l'udovej strave po roku 1945, odkedy možno zaznamenávat' neustále zvyšovanie hmotnej úrovne l'udu vplyvom dobrých zárobkov v priemysle a pri t’ažbe dreva. Toto zlepšenie sa prejavilo v pestrejšom jedálnom lístku a vo zoýšenej starostlivosti o prípravu jedál. (...) Začína sa varit pravidelná teplá strava, ktorá v rámci týždňa vrcholí nedelným obedom. No tieto zmeny možno pozorovat' viac-menej len v rodinách, ktorých príslušníci pracujú v továrňach. Zatial u drevorubačov zostáva podnes základom suchá strava, spočívajúca v kaloricky výdatných jedlách, hlavne v slanine a vajíčkach. Pravidelné podávanie teplých jedál po roku 1945 bolo skutočne pokrokom v l’udovej strave, pretože napr. deti v období predmníchovskej republiky dostávali varené jedlá iba raz denne, pričom doplnkovú čast' ich letnej stravy tvorili zbierané, divo rastúce lesné a pol'né plodiny, ako čučoriedky, jahody a pod. Význam tohto zberného hospodárenia v horehronskej l’udovej strave hrá úlohu aj v súčasnosti a bude úlohou budúcich výskumov všímat' si túto otázku podrobnejšie. $V$ hospodársky pokročilejších družstevných dedinách, napríklad v Lábe, tvorí významný medzník vo vývine l’udovej stravy počiatok spoločného varenia po celý rok $v$ školskej družine a v jasliach. Úroveň varenia v spoločných kuchyniach je pomerne vysoká, preto niet divu, že spoločné kuchyne si za krátky čas získali dôveru dedinského družstevného kolektívu“ (Podolák: 1955, 268 - 277).

Ďalší etnografický výskum kulinárnej kultúry prebiehal v roku 1954 a súvisel s najvýznamnejším dobovým projektom, spracovaním monografie Banícka dedina Žakarovce, ktorá vyšla v roku 1956. Z hl'adiska etnológie išlo vtedy o prelomový výskum, ktorým sa mal dobový národopis etablovat' v rámci marxisticko-leninského chápania kultúry.

V úvode tejto práce Božena Filová okrem iného napísala: „..Po proý raz v histórii slovenského národopisu sa čitatel'om dostáva do rúk súborná historicko-národopisná monografia, spracovaná na základe výskumu robotníckej triedy na Slovensku. (...) Prečo až teraz dochádza k prvému výskumu robotníckej triedy? Doterajšie výskumy a práce z odboru náro- 
dopis považovali za nositel'a kultúry a tradící v národe iba l’ud rol’nícky, pripútaný $k$ pôde ako hlavnému výrobnému prostriedku, kým proletariát zámerne podceňovali (...) tordiac, že robotnícka trieda svojím charakterom, nestálym zamestnaním, častým menením pracoviska nie je schopná vytvorit’ si svoju kultúru, nemôže byt’ nositel’om národných tradícií. Našou úlohou je dokázat', že históriu nášho národa (...) i jeho národné zvláštnosti a tradície vytvárali vedl'a seba pracujúce rol’níctvo a robotnícka trieda. (...) Vo svojej práci chceme ukázat', že naša robotnícka trieda nie je beznárodná, ale naopak, sú v nej hlboko zakorenené všetky národné city, svoju národnú hrdost’ a charakter udržuje aj medzi robotníkmi iných národností, i pod vládou cudzích kapitalistov. Robotnícka trieda popri hlbokej národnej hrdosti je internacionálna. (...)

...Výskum robotníckej triedy robíme v období, ked' sa naši pracujúci zbavili vykorist'ovania a vydali sa cestou budovania lepšieho zajtrajška robotníkov, pracujúcich rolníkov a pracujúcej inteligencie. Na základe spoločenského vlastníctva výrobných prostriedkov, ktoré l'ud nerozdel'uje, ale spája, zakladaním rolníckych družstiev, budovaním socializmu na dedine postupne slabnú a miznú antagonistické triedne rozdiely medzi našimi pracujúcimi. (...) Ak touto prácou chceme aj my pomôct' naznačit’ cestu, po ktorej sa má uberat’ vývoj nášho národa do beztriednej spoločnosti, musíme dôkladne poznat' vznik jednotlivých tried. (...)

Robotníckej triede v súčasnej dobe patrí u nás miesto vedúcej sily nášho l'udu. Touto prácou chceme ukázat', že vedúcou silou sa nestala náhodou, ale že má dlhé, bohaté a bojové tradície..." (Filová: 1956, 5-8).

Etnografia 50. rokov 20. storočia sa touto prácou zjavne chcela prihlásit’ k politicky žiadanému objektu svojho výskumu. Avšak na to, aby sa skutočne pokúsila skúmat’ robotnícku triedu v rámci industrializovaného urbánneho prostredia, si netrúfla alebo skôr nemala dostatok vedomostí a výskumných zručností, ako takýto výskum realizovat'. Zostala preto v komornejšom rurálnom prostredí a na výskum použila osvedčené etnografické výskumné techniky. Napriek tomu, že baníci v Žakarovciach boli prezentovaní ako robotnícka trieda, išlo skôr o sociálno-profesijnú skupinu pracujúcich v baniach so silným historickým a kultúrnym zakorenením v tradič- 
nom rurálnom prostredí. To si zjavne uvedomovala aj B. Filová, ked” v úvode tak dôrazne akcentovala "národný" charakter slovenského robotníctva, ktorý však dost’ dobre nezapadal do marxisticko-leninského chápania robotníckej triedy ako „internacionálnej revolučnej sily, ktorá hýbe dejinami“.

Kapitolu o strave do tejto knihy koncepčne pripravil a spracoval Michal Markuš. Okrem historickej genézy spôsobu stravovania Žakarovčanov sa pokúsil analyzovat’ aj ich vtedajšiu úroveň stravy. Využil na to anketu, ktorá sledovala týždenné jedálne lístky (raňajky, obed, večeru), ktorú vypíňali staršie (10- až 14-ročné) školopovinné deti. Dá sa predpokladat', že sa pri takto realizovanom výskume inšpiroval prácami dietológov.

Sto skúmaných rodín rozdelil na kategórie podla zamestnania mužov, z ktorých 90 \% tvorili robotnícke profesie (baníci, penzionovaní baníci, železničiari, robotníci). Analýzu jedálnych lístkov M. Markuš sumarizoval takto: „...Dnešné raňajky vo viac ako 56 \% pozostávajú z bielej kávy alebo mlieka, aj pri večerách je to $20 \%$. (...) Bolo by žiaduce, aby v priemernej strave dospelých Žakarovčanov bolo aspoň tol'ko mlieka, kol'ko je chlebovej múky. (...) Medzi raňajkami sa občas objavia aj tradičné jedlá ako domikát (chlebová polievka s bryndzou alebo zápražkou) a dost' častá je aj čierna káva s chlebom s mastou, maslom, bryndzou. Toto sú prirodzene novšie jedlá. Chlieb sa jedol takmer ku každému jedlu. (...) Obedy pozostávajú z jednochodových jedál. Len v nedel’u sa rozšíria na dvojchodové. Je vel'mi pozoruhodné, že väčšinu majú jedlá kašovité, mäsité (najčastejšie guláš), polievkovité, haluškovité (skoro 62 \%), čo sú zväčša tradičné staré jedlá (napr. halušky, krúpy, kaša, polievky). Najtypickejšie obedy pre žakarovskú kuchyňu sú krúpy a halušky s bryndzou. (...) Bryndza sa konzumuje aj inokedy, na večeru často chlieb s bryndzou. Inakšie sú na večeru obyčajne zvyšky od obeda a mlieko alebo káva s chlebom. (...)

...V súvislosti s uvedenými jedálnymi lístkami sa môže vynorit’ otázka, aká je spotreba menovaných jedál v Žakarovciach. Žial', na túto otázku nemôžu dat' uspokojivú odpoved' ani dotazníky, ani ziskané informácie. Miestne biologické účinky stravovania môže úspešne skúmat’ odborník - 
lekár alebo biológ. (...) Táto úloha sa však vymyká z okruhu záujmu národopisu. (...) Teraz pokladáme za dôležité len poznamenat', že hoci sa stravovanie obce po stránke biologickej ešte dnes nemôže pokladat’ za bezchybné, ak prebehneme výsledkami dosiahnutými na tomto poli za posledných 100 rokov a vyhodnotíme dnešný stav, ku ktorému sme dospeli po mnohých zmenách, môžeme byt’ v konečnom výsledku s priebehom vývinu spokojní..." (Markuš: 1956, 314 - 319).

Ked' analyzujeme jeho kapitolu o tradičnej strave, je celkom zrejmé, že aj pri tomto metodologicky a ideologicky „prelomovom“ výskume sa jej autor zameral najmä na historicko-genetické vývinové fázy jednotlivých jedál, nápojov a kuchynského inventára. Márne v ňom hl'adáme robotnícke kulinárne špecifiká, ktoré by sme v takto zameranom výskume predpokladali. Sám M. Markuš to komentuje takto: „...Treba odpovedat' aj na otázku, aké je stravovanie Žakarovčanov. Pravdu povediac nemôžeme dat' presnú a rozhodnú odpoved'. Naše údaje môžu poskytnút' len približný obraz, z ktorého nesmieme a ani nemôžeme vyvodit konečné závery" (Markuš: 1956, 314).

Je však evidentné, že výskum v Žakarovciach a spracovanie kapitoly o strave do monografie bola pre M. Markuša impulzom, aby sa začal systematicky venovat’ problematike kulinárnej kultúry. Pri koncipovaní tejto kapitoly iste nemal l’ahkú úlohu, čo aj sám komentoval: „....Musíme konštatovat', že sme sa pri tejto práci nemohli opierat’ o porovnávací národopisný materiál. Otázka slovenského l'udové stravovania je najzanedbávanejšou oblast’ou slovenského národopisu..." (Markuš: 1956, 283).

V archíve Ústavu etnológie SAV sa nachádzajú aj výskumné materiály M. Markuša z rokov 1955 - 1961, ktoré realizoval pre svoju kandidátsku dizertačnú prácu L’udová strava na Horehroní, obhájenú v roku 1967, a ktoré použil aj pri tvorbe kapitoly „Strava“ v monografii Horehronie II (Markuš: 1974, 121 - 169). V histórii slovenskej etnografie bola táto dizertačná práca prvou regionálnou monografiou o tradičnej kulinárnej kultúre, spracovanou komplexne, v celej šírke tejto problematiky. V práci sa $\mathrm{M}$. Markuš zameral predovšetkým na najstaršie archaické formy a názvy jedál (od druhej polovice 
19. storočia) a sledoval ich postupné premeny, prípadne zánik až do času výskumu. Tento metodický postup sa snažil zachovat’ v každej kapitole práce (aj ked' nie dôsledne), čo umožňuje analyzovat’ stav a premeny stravovania horehronského obyvatel'stva v období socializmu detailnejšie:

„...V súčasnosti sa stala kuchynským priestorom vaškuchyňa, postavená pri obytnom dome. $V$ nich sa ešte nachádzajú staršie murované šparhety, ale vo väčšine z nich sa na varenie použivajú moderné stolné šporáky. (...) V súčasnosti sa zvyknú usporadúvat' kurzy varenia, na ktorých sa najmä mladšie ženy oboznamujú s prípravou doteraz neznámych pokrmov, napríklad: zákuskov a tort, vyprážaného mäsa, pečenej sliepky, závinov, kysnutých knedlí, bratislavských rožkov, volského oka, zemiakových palaciniek atd’... Vel'ký záujem je o kuchárske knihy, napríklad v Polomke ich predali v roku 1957 až 140 kusov. (...) Vo väčšom meradle sa na Horehroní začalo zavárat’ až po druhej svetovej vojne. Súviselo to so zavedením systému potravinových lístkov, kedy bol na každú osobu stanovený prídel cukru. Takto si obyvatelia zoykli na pravidelné používanie cukru. V súvislosti s tým stúpla spotreba rôznych sladkostí, koláčov, pečív a bielej kávy. Priemerná spotreba cukru stúpla v porovnaní s rokmi prvej svetovej vojny trojnásobne. Ked’že miestne obyvatel'stvo nebolo navyknuté na také množstvo cukru, používali mladšie gazdiné nespotrebovaný zvyšok z prídelu na zaváranie lesného ovocia. (...) Najmladšie gazdinky si tiež osvojili nakladanie uhoriek soctom. (...) Zásobenie múkou na Horehroní v súčasnosti s pomermi koncom minulého a začiatkom nášho storočia nemožno vôbec porovnávat'. Kým v minulosti bolo zásobovanie sporadické, viac menej náhodné, príležitostné, v súčasnosti dostávajú predajne Jednoty pravidelne raz za dva týždne prídely čerstvej múky, takže obyvatel'stvo nikdy nie je bez múky. V súvislosti s väčšimi sviatkami sa spotreba múky až zdvojnásobuje. $V$ súčasnosti sa v horehronskej kuchyni používajú tri druhy múky: hrubá, polohrubá a hladká. Záujem je aj o kukuričnú múku, ktorá je dostat’ len občas a rýchlo sa minie. Pri rozvoze dostávajú predajne Jednoty $50-60$ q tejto múky, avšak to je málo čo i len na ochutnanie. (...) Najnovšou a obl’úbenou kašou je na Horehroní gríz alebo grízik, varený z jemne pomletej pšeničnej krupičnej múky. Kašu pripravujú oboykle vtedy, ked’ ju lekár 
predpíše chorému alebo pre deti. Kaša sa tu rozšírila až po 2. svetovej vojne a možno predpokladat', že sa stane rozšíreným jedlom. (...)

...Od konca druhej svetovej vojny obstarávajú zásobovanie obyvatel'stva chlebom pekárne. Prídel chleba, určený v povojnových rokoch potravinovými lístkami, dodávali tieto pekárne. Táto forma zásobovania chlebom naučila tunajšie obyvatel'stvo používat' namiesto podomácky pečeného chleba výrobky spomínaných pekární. $V$ dôsledku toho sa v súčasnosti na Horehroní s domácim pečením chleba už nestretávame. V súčasnosti sú na Horehroní tri pekárne: v Polomke, Pohorelej a Švermove (Telgárte). Produkujú mesačne približne 100 - 150 ton chleba a vo všetkých pečú chlieb čierny, ktorý je oblúbenejší, a biely. Pečú sa trojkilové pecne chleba. Za rok spotrebujú obyvatelia tohto regiónu cca $96 \mathrm{~kg}$ čierneho chleba a 5,4 kg bieleho chleba na osobu. (...) Nadbytok cukru, ktorý domácnosti dostávali lístkovým systémom, umožnil gazdinám piect’ sladké múčniky: zákusky nazývané kusy, piškóty a torty. V horehronskej strave to bola novinka, ktorú si osvojili najmä mladšie ženy. Tie sa ich naučili piect’ od miestnej inteligencie, ale najviac na kurzoch varenia a pečenia. Spočiatku sa piekli na svadby, krstiny, neskôr aj na vel'ké cirkevné sviatky. Je zaujímavé, že k pečeniu sladkých múčnikov povzbudzovali ženy mnohí mladí chlapi, ktorí sa vrátili z vojny. Preto nečudo, že si ženy kupujú kuchárske knihy a začinajú experimentovat'. Aj torty sa spočiatku pripravovali len na výnimočné príležitosti. Ženy, ktoré si na jej pečenie netrúfajú, objednávajú si ju u pekára v Brezne alebo donesú suroviny na jej upečenie skúsenejšej žene alebo cukrárovi. Torta je dnes najpopulárnejším svadobným pečivom a pomaly preberá funkciu niekdajšieho svadobného koláča. Podomácky pripravené torty ženy rôzne dekorujú, v rokoch výskumu bolo napríklad v Pohorelej módou upiect' svadobnú tortu vo forme knižky a vo vnútri bola šikovne ukrytá flaša rumu. Na prelome 50. - 60. rokov prichádzajú do módy aj poschodové torty. (...) Horehronské obyvatel'stvo konzumuje aj značné množstvo pekárenského bieleho pečiva: tukové rožky, brijošky, vianočky, lúpačky, šatôčky, záviny. Žemle miestne pekárne pečú len v minimálnom množstve alebo vôbec. Biele pečivo sa predáva priamo v pekárňach, predajniach Jednoty, bufetoch, reštauráciách. (...) Konzum bieleho pečiva oproti minulosti značne stúpa. (...) V súčasnosti sa už ku- 
pujú aj cestoviny vyrábané priemyselne. Kedysi neboli v horehronskej kuchyni vôbec známe, ich zvýšená spotreba začala až po 2. svetovej vojne. Najoblúbenejšie sú nit’ovky. Ostatné druhy: mušle, fliačky, krúžky, slovenská ryža a pod. sa kupujú len v prípade, že nedostat’ nit’ovky. (...) V súčasnosti sú na Horehroní tri spôsoby získavania zeleniny: pestovaním na záhradách, nákupom v predajniach Zelovoc a nákupom od JRD. Množstvo zeleniny získanej proým spôsobom je takmer zanedbatel'né. Ani predajne Zelovocu nie sú schopné uspokojit dopyt obyvatel'stva. Čerstvý tovar je vypredaný za niekol'ko hodín. Najčerstvejšia zelenina prichádza na Horehronie vtedy, ak sem niektoré JRD z južného Gemera pošle traktor s vlečkou plnej zeleniny. Dopyt po zelenine je v regióne značný. Ak niet čerstvej zeleniny, minie sa i zelenina naložená v konzervách. (...) Aj dopyt po ovocí je v súčasnosti vysoký, a ani v tomto prípade nevie obchodná a distribučná siet' plne uspokojit zákazníkov. Vel'ký dopyt je po nedostatkovom južnom ovocí, citrónoch a pomarančoch. Vzrástla len spotreba podomácky konzervovaného lesného ovocia. (...)

$V$ takmer každej väčšej obci na Horehroní je predajňa mäsa, ktoré sú zásobované z Brezna. Týždenne sa v nich minie 6 - 7 q mäsa. (...) V porovnaní s údajmi z minulosti vidíme, že napríklad v roku 1954 vzrástla spotreba mäsa oproti roku 1931 pätnásobne. (...) Stáva sa však, že predajne mäsa nevedia plne uspokojit' nároky obyvatel'stva. V prípade nedostatku čerstvého mäsa nakupuje obyvatel'stvo mäsové konzervy. Spotreba čerstvého mäsa je vyššia v zime, kým v lete je dopyt po ňom menší, kupujú sa skôr údeniny: klobása, saláma a slanina. Tieto potraviny sú výhodnejšie na prenášanie do polí, kde si ich l’udia berú ako stravu vobdobí pol’ných prác. (...) V škále konzumovaných polievok v súčasnosti nachádzame v tomto regióne nedávno zavedený guláš, pripravovaný z najlacnejšieho mäsa, prípadne len z klobásy a zemiakov. (...) Aj užívanie bravčovej masti - šmalca - na mastenie jedál je na Horehroní úplne novým javom a súviselo to so systémom potravinových lístkov. Na čast', tukových' lístkov bola v predajniach vydávaná mast', a tak si na ňu gazdiné začali privykat’. (...) Na Horehroní môžeme vidiet' výraznú tendenciu miestneho obyvatel'stva zadovážit' si vlastné zásoby domácim chovom ošípaných. Je pri tom schopné prekonat' naj- 
rôznejšie prekážky, jednou z nich je nedostatok krmovín. Ich úsilie v tomto smere vysvetl'uje fakt, že väčšina mužov t’ažko fyzicky pracuje a potrebujú kaloricky bohatú stravu, ktorú nie je možné vždy zaobstarat’ vobchode. (...) Mäso dnes nie je tak ako v minulosti výlučne sviatočným jedlom, konzumuje sa aj vo všedné dni. Namiesto soleného baranieho mäsa sa konzumuje čerstvé hovädzie a bravčové mäso. (...) Popri varení sa mäso pripravuje aj pečením a vyprážaním. Vhorehronskej kuchyni v tomto období zdomácneli viaceré mäsové jedlá: guláš, bravčové rezne - šnicle, fašírka a iné. Stúpla aj spotreba živočíšnych tukov. (...)

...Preváranie mlieka nebolo v minulosti na Horehroní obvyklé. Rozšírilo sa až v súvislosti s varením bielej kávy s cukrom, čo sa robí v súčasnosti každodenne. (...) Bryndza je dodnes oblúbeným jedlom. Jej domáca výroba zanikla a jej výrobu zabezpečuje priemysel. Ovči syr z horehronských salašov spracúva bryndziareň v Tisovci. Po bryndze je velký dopyt, tak sa v obchode rýchlo minie. Zamestnanci predajní tordia, že aj keby bryndziareň dodávky zdvojnásobila, i to by sa minulo. (...) Dnes sa už oštiepky na Horehroní nevyrábajú. (...)

...O zásobovaní vodou na Horehroní môžeme všeobecne povedat', že postúpilo dopredu mílovými krokmi. Ešte v minulej generácii bolo obvyklé nosenie vody z potoka, kým v súčasnosti má každá domácnost’ vodovod. (...) Z nealkoholických nápojov sa okrem bielej kávy pije najčastejšie ruský alebo bylinkový čaj... Spotreba pálenky je v regióne tradične vysoká. Dnes sa konzumuje najčastejšie domáca varená pálenka nazývaná lavórovica alebo jedenást'ka. Jej surovú chut' l'udia paralyzujú pridávaním a namáčaním korenia a liečivých bylín... Spotreba vína na Horehroní nedosahuje celoštátny priemer. Skôr sa pije pivo. (...)

...Väčšina tradícií spojená s jedením prešla v uplynulom období mnohými zmenami... Tento proces je mimoriadne výrazný najmä v súčasnom stave prechodu $k$ socializmu. Jeho najvýraznejším nositel'om je mladšia generácia... Dnes už na mnohých miestach varia ženy aj na obed vo všedný deň čerstvé jedlo, čo sa v minulosti nerobilo... Ženy jedávajú za jedným stolom s mužmi. (...) Dnes sa začína jest’ vel'mi často bez modlitby, v najlepšom prípade sa l'udia len rýchlo pokrižujú...

...Dochádza aj k postupným zmenám pri jedlách podávaných pri príle- 
žitosti cirkevných a rodinných sviatkov. (...) Dnešná štedrovečerná večera sa v porovnaní s tradičnou príliš nezmenila. Zmenou je obohatenie tradičného menu (oplátky, med, kyslá polievka s hubami, lokše alebo opekance s medom a makom, varený hrach, kaša s mliekom, sušené slivky, hriata pálenka a po polnoci klobása, studenica, oškvarky) o niektoré mäsité jedlá a jemnejšie druhy koláčov a pečiva.

\section{...Dnes už pôsty zachováva málokto. (...)}

...Po druhej svetovej vojne sa vytvorila a ustálila všeobecne prijatá a zaužívaná forma nosenia jedla šestonedielke. Po pôrode $k$ nej prichádza kmotra s vel'kou misou naplnenou bôbom, hrachom, krúpami alebo najnovšie ryžou a 15 - 20 vajcami. Na druhej mise sú 2 - $3 \mathrm{~kg}$ slaniny alebo mäsa a koláč. Misy sa nesú zaviazané v obruse. Novšie sa koláč nahrádza graplami (vyprážaným pečivom), zákuskami či tortou, ktoré sa nesú v koši. K tomu sa pridá flaša pálenky. (...) Ak vezmeme do úvahy, že tieto dary prináša 4-5 kmotier, potom množstvo nahromadených potravín je skutočne úctyhodné. Vysvetlenie spočíva $v$ tom, že v minulosti chýbal potrebný hospodársky základ, patričná hospodárska základña, ktorá by umožňovala prinášanie takýchto bohatých darov. V ére socializmu odpadajú problémy $v$ súvislosti so získavaním potravín, preto sa aj tento zvyk mohol natol'ko rozvinút'. (...)

...Tradičné svadobné jedlá (varené mäso, kapusta, krúpy, kaša, pálenka) sa v podstate uchovali. (...) K vä̌̌ším zmenám došlo len pri koláčoch, ked' boli tradičné svadobné pečivá nahradené novšimi zákuskami a tortami. Postupne sa tiež vynecháva prinášanie potravinových darov: krúp, mäsa, posúchov pozvanými hostami. Namiesto toho prinášajú tortu. (...) $\mathrm{Na}$ kare sa dnes $k$ tradičnému chlebu a pálenke podáva aj pražené mäso, vyprážané pečivo - graple a zákusky - kusy..."

$\mathrm{V}$ osobitnej časti dizertačnej práce sa M. Markuš pokúsil akcentovat' v čase jeho výskumov zavádzané nové ",socialistické“ tendencie v stravovacích modeloch miestneho obyvatel'stva. Na to použil informácie, ktoré získal zo závodných jedální podnikov TATRASMALT v Pohorelskej Maši, SIGMA v Závadke nad Hronom a z Materskej školy v Šumiaci:

„,...Obraz o súčasnom stave stravovania na Horehroní by nebol úplný, 
keby sme vynechali jedálny lístok závodných kuchýň a jedální, ktoré majú za úlohu zabezpečit’ stravovanie zamestnancov cez pracovný čas. Tieto inštitúcie sú novšieho pôvodu a možno ich vlastne označit' za výdobytky socialistickej spoločnosti. (...) Špecifickou je závodná kuchyňa zabezpečujúca stravu pre drevorubačov a lesných robotníkov. V blízkosti rúbaniska v lese je zriadený drevený prenosný barak s kuchyňou, v ktorej varí miestna žena. Stravovanie sa začína v pondelok obedom a končí sobotnými raňajkami. (...) Pri zostavovaní jedálneho lístka berie kuchárka ohl'ad na miestne tradície a oblúbené jedlá. Na raňajky sa varia halušky, na obed sa podáva suchá strava (slanina, chlieb) a na večeru je takmer každý deň mäso s prívarkom alebo kašovitým jedlom. (...) Zriadenie a trvanie tejto závodnej kuchyne znamená vel'ký krok vo výžive týchto fyzicky t’ažko pracujúcich mužov. Robotníci sami sú s kuchyňou spokojní, okrem toho sú ušetrení starostí so zaobstarávaním potravín a varením jedál počas týždňových pobytov v lesoch. (...)

...Na Horehroní sa tiež dnes stretávame so závodnými kuchyňami $v$ dvoch priemyselných podnikoch. Závodnú jedáleň v Závadke vedie RaJ (Reštaurácie a jedálne) a jedáleň pri závode v Pohorelskej Maši spotrebné družstvo Jednota. Jedálne lístky sú tu zostavované podl'a československých štátnych noriem. (...) Jedálne lístky kontroluje a odobruje závodná stravovacia komisia. (...) Úroveň jedálnych lístkov často však závisí od možností nákupu potravín. (...) Robotníci, zamestnanci v spomínaných podnikoch pracujú obvykle na tri zmeny, podl'a toho dostávajú v závodnej kuchyni bud' obed, alebo večeru. Výhody tohto stravovania využívajú skôr robotníci zo vzdialenejších obcí, tí ktorí bývajú bližšie sa stravujú obvykle z donesených zásob z domu. (...)

...Školskú jedáleň pri materskej škole v Šumiaci spravuje miestne MNV (miestny národný výbor). Chodia sem deti zamestnaných rodičov a v školskej jedálni dostávajú desiatu, obed a olovrant. (...) Kuchárkou je tam miestna žena, ktorá má zásluhu na tom, že sa tam varia jedlá podl'a miestneho vkusu. (...) Éra socializmu vtisla horehronským det’om namiesto núdzových potravín do ruky kus chutného chleba a dáva im aj perspektívu istoty a radostnej budúcnosti..."

Z týchto etnografických lokálnych mikroanalýz stravovacích 
modelov viacerých dedinských komunít prevažne z Horehronia v období 50. a prvej polovice 60 . rokov 20. storočia možno sumarizovat:

V súvislosti s lístkovým systémom pridelovania potravín zvyšovala sa konzumácia kupovaného chleba, cukru, bravčovej masti. Do jedálneho lístka vidieckeho obyvatel'stva boli zarad'ované nové jedlá, napr. pečené a vyprážané mäsité jedlá, biela káva, biele pečivo, múčniky, torty. Do stravy začali prenikat’ výrobky potravinárskeho priemyslu: mäsové, rybie a zeleninové konzervy, kompóty, cestoviny. Potraviny sa začali predávat’ v predajniach Jednota a rozširovali sa aj špecializované predajne potravín ako pekáreň, zelovoc, mäsiarstvo, ktoré však mali vážne problémy so zásobovaním. Začali pracovat’ spoločné vývarovne v školských a predškolských zariadeniach. Začali fungovat' závodné jedálne pre robotníkov. Zvyšovala sa osveta v oblasti stravovania.

Etnografický výskum socialistickej dediny a spôsobu života ludí v nej pokračoval zhruba o nasledujúcu generáciu, v rokoch 1976 - 1980, ked' sa táto úloha riešila v Národopisnom ústave SAV pod názvom L’udová kultúra v podmienkach socialistickej spoločnosti a výsledky boli zhrnuté a uverejnené v práci Spôsob života družsteonej dediny (1986). V jej úvode editor práce Adam Pranda konštatoval: „... Práca predstavuje relatívne ucelený súbor analytických sond do vybraných problémov spôsobu života konkrétnej sledovanej obce (Sebechleby), ktoré sú z hl'adiska poznania najnovšieho štúdia procesu zmien družstevnej dediny u nás najpríznačnejšie a ktoré ovplyvňujú, alebo môžu ovplyvňovat” formujúci sa socialistický spôsob života v našej spoločnosti..." (Pranda: 1986, 10).

Jedna z týchto sond bola venovaná kulinárnej kultúre skúmanej lokality, ktorá v tom čase patrila už k stabilizovanej a prosperujúcej družstevnej obci v Honte na južnom Slovensku.

Strava sa sledovala na základe týždenných jedálnych lístkov. (...) Ešte aj dnes sa pripravujú ,silné rolnícke raňajky', varené alebo pečené jedlá. Gazdiná musí skoro vstávat', aby bolo jedlo prichystané pred odchodom členov rodiny do práce alebo do školy. Často sa varia halušky 
s tvarohom alebo bryndzou, rezance, prípadne iná cestovina, vývar z halušiek okorenený octom a cesnakom, polievka z kyslej kapusty, pečú sa placky s tvarohom, zemiakmi, kapustou či lekvárom, pagáče z kysnutého cesta. Jedlá sa zapíjajú mliekom alebo bielou kávou. (...) Obed sa zvyčajne podáva, ked’ sa členovia domácnosti vrátia z práce alebo zo školy. (...) Obedy sú výdatné a väčšinou dvojchodové, skladajú sa z polievky a druhého jedla. Konzumujú sa mäsité jedlá aj zeleninové jedlá. Toto zloženie stravy prevláda v lete, ked' je dostatok zeleniny, hydiny, králikov a pod. V zimnom a jarnom období sa často pripravujú jedlá zo zemiakov, kyslej kapusty, cestoviny a mäso zo zabíjačky. Na jedálnom lístku sa pravidelne v piatok objavujú pôstne jedlá - cestoviny a strukoviny. Pondelok je akýmsi ,dojedacím dňom stravy pripravenej na nedel'u. (...) Na rozdiel od pomerne náročných obedov je večera väčšinou jednoduchá - varené, pečené alebo "gniavené" zemiaky s maslom, oškvarkami, s kyslým alebo sladkým mliekom. Niekedy sa na večeru uvarí polievka a dojedajú sa zvyšky od obeda. (...) Okrem toho sa pripravujú desiate pre členov rodiny, ktorí pracujú mimo obce, vo vinohradoch a pre deti do školy. Zvyčajne je to chlieb, klobása, slanina, v lete doplnené paradajkami a paprikami. Olovrant popoludní je menej praktizovaný. Podáva sa najmä detom, ktoré sa vrátili zo školy, a pre malé deti, ktoré sú doma. (...) V obci sú však aj domácnosti, kde sa cez týždeň pravidelne nevarí, pretože matka je zamestnaná mimo dediny a stravu môže pripravit' až po príchode domov. (...) Najväčší význam pripisujú ludia nedelnému obedu, na ktorý sa zvyčajne varí mäsová polievka (hovädzia, hydinová), pripravia sa dva druhy mäsa, ktoré sa nakupujú v miestnom mäsiarstve alebo v blízkych mestách. K mäsu sa podávajú zemiaky alebo ryža, rôzne prívarky a omáčky. V skladbe nedel'ného obeda nesmú chýbat' rôzne koláče, zákusky, štrúdl'a a pod. Najmä v posledných rokoch sa podl’a nových receptov z časopisov a kuchárskych kníh pečie široká paleta zákuskov. (...) Príprava stravy v Sebechleboch je po kvantitatínej i kvalitatívnej stránke na vysokej úrovni. Na dobrej úrovni je aj vybavenie kuchýň rôznymi zariadeniami na varenie a pečenie a chladničkami. (...) Rodina stoluje spoločne predovšetkým v nedel'u na obed a pri rozličných sviatočných príležitostiach a sviatkoch, cez všedné dni sa členovia rodiny stravujú podl'a potreby a príchodu z práce alebo zo školy. (...) 
...Väčšina svadobných hostín sa neodohráva na rozdiel od minulosti $v$ svadobných domoch, ale v priestoroch dedinského kultúrneho domu. Na tých to hostinách sa zúčastrúuje široké príbuzenstvo a známi, takže je celkom bežné, ak sa zíde 150 - 200 hostí. Do svadobných domov sa pozývajú už týždeň vopred profesionálne svadobné kuchárky a ich pomocníčky z príbuzenstva. Varí a pečie sa v podstate vo všetkých miestnostiach svadobných domov, niekedy na to prispôsobia stodolu alebo sa variče a rúry vynesú na dvor. V svadobných domoch sa robí zabijačka ošípanej, urobia sa klobásy a hurky a mäso sa pripraví na pečenie, na vyprážané rezne a pomelie sa do fašírok. Z mäsa sa dokupuje len hovädzina do fašírok a šunka v konzerve. Zároveň s tým začínajú do svadobných domov príbuzní a známi, pozvaní na svadbu, nosit’ potraviny: múku, cukor, vajička, olej, umelý tuk, orechy, kakao, čokoládu alebo peniaze na ich nákup. Bližšia rodina nosí hydinu: sliepky a kurčatá. Kuchárky narobia vel'ké množstvo domácich rezancov do slepačej polievky, na ktoré spotrebujú až 50 - 70 vajec. Na svadbu sa upečie niekol'ko tort a aj pät’desiat druhov zákuskov. Z nápojov sa podáva sladká (kávová, hrušková) aj tuhá (hruškovica, slivovica, jablkovica) pálenka, víno, pivo, pre deti malinovka. (...) Na svadbách v Sebechleboch v čase výskumu sme zaznamenali niektoré tradičné zvyky spojené s darovaním potravín. Od birmovnej matky má nevesta dostat' vel'ký zdobený obradový koláč ,radostník's papierovou výzdobou, od krstných rodičov ženích aj nevesta majú dostat' 6 - 9 kusov domácich chlebov a od rodiny krstných detí 5 kusov ,bosvanov' - vysokých kysnutých koláčov. Po dohode s mladomanželmi sa im namiesto ,bosvanov' dávajú napríklad peniaze, kávová súprava alebo iné vecné dary. Stále však pretrváva darovanie ,radostníka', z ktorého dostávajú svadobní hostia po kúsku na pamiatku. Vysoko sa cenia aj domáce chleby upečené v peci na drevo a domáce rezance, ktoré sa dávajú aj ako súčast', výslužky'. (...) Súčasná ekonomická prosperita obyvatelov obce sa výrazne odráža aj na kvalite aj kvantite svadobných hostín, negatíva sú spojené predovšetkým s priestormi v kultúrnom dome, v ktorom nie je kuchyňa a jedlá sa tam musia zo svadobných domov vozit' a riad umývat' $v$ provizórnych podmienkach...

...Zásobovanie obyvatelov potravinami je zabezpečené samoobslužnou predajňou potravín, predajňou zelovoc a mäsiarstvom. 
Počet obchodov a niekedy aj ich sortiment však obyvatelom nepostačujú a uvítali by ich rozšírenie a zlepšenie zásobovania. (...) Verejné stravovanie zabezpečuje v obci Pohostinstvo, ktoré patrí podniku Jednota. Okrem nápojov sa tam dajú kúpit’ studené jedlá (salámy, klobásy, syry, pečivo, sladkosti) a na objednávku teplé obedy. Služby pohostinstva využívajú po celý rok niektorí zamestnanci JRD, ktorí sa tam stravujú, a v letnom období aj brigádnici pracujúci na JRD. Prevažná väčšina obyvatel'stva, aj tí, ktorí pracujú mimo obce, sa však stravuje doma. Len niektorí z nich sa stravujú $v$ závodných jedálňach. Väčšina mladých žien, ktoré majú deti v materskej škole a v škole, je s úrovňou a kvalitou stravovania v týchto zariadeniach vel’mi spokojná. Horšia situácia je v stravovaní mládeže, ktorá navštevuje školy mimo obce. Väčšina z nich si berie so sebou suchú stravu alebo si niečo kúpia v meste. Teplé jedlo konzumujú až po príchode domov, často až večer. Rôznorodost' v stravovaní je aj u l'udí, ktorí pracujú mimo dedi$n y$, ale aj u pracovníkov na miestnom JRD. Väčšina z nich sa stravuje len doma. Ošetrovatel'ky dobytka (krmičky, dojičky a pod.) sú vyṫažené skoro ráno a v podvečer, takže medzitým stihnú navarit' pre rodinu, aj sa najest'. Ženy pracujúce v rastlinnej výrobe si jedlo navaria väčšinou večer na nasledujúci deň a jedlo si berú so sebou na pole. Niektorí muži, zamestnanci $J R D$, obedujú v jedálni pohostinstva, ale mnohí chodia na obedy domov...

...Súčasná úroveň stravovania v Sebechleboch je výsledkom mnohých zmien, ktoré prebehli v obci za posledné desat'ročia. Kúpyschopnost' obyvatel'stva vzrástla, čo sa prejavuje aj v zložení stravy. Strava je výdatná, pestrá a nechýbajú v nej ani tzv. luxusné potraviny. Aj vybavenie kuchýn̆ sa zmenilo. V nových a v rekonštruovaných domoch je bežné moderné zariadenie ul’ahčujúce a urýchlujúce prípravu jedál. Najmä mladšia generácia kladie už dôraz aj na kultúrne stolovanie a estetické prostredie kuchýň" (Stoličná: 1986, 118 - 124).

Z obsahu prípadovej etnografickej štúdie z prostredia prosperujúcej družstevnej socialistickej obce v regióne Hontu o úrovni stravovania jej obyvatel'stva druhej polovice 70. rokov 20. storočia vyplýva:

V stravovacích modeloch obyvatel'stva ešte stále pretrvávali niektoré prvky tradičnej rol’níckej kultúry: napríklad príprava a konzumácia teplých raňajok pred odchodom členov rodiny do práce ale- 
bo darovanie rituálnych potravín v rodinných obradoch. Na rozdiel od minulosti boli aj obedy vo všedné dni výdatné. Vel'ký význam sa kládol na kvalitu a kvantitu nedelných obedov, čo na dedinách nebývalo kedysi bežné. Rozšírené bolo stravovanie detí v predškolských a školských jedálňach. Pracovníci JRD mali možnost’ stravovat' sa v miestnom „Pohostinstve“, čo však väčšinou nevyužívali a preferovali stravovanie doma. V obci už bola samoobslužná predajňa potravín. Zásobovanie potravinami bolo obyvatel'mi hodnotené pomerne kriticky. Členovia JRD, ktorí stratili svoje súkromné hospodárstva, svoj sociálny status prejavovali inými formami, v ktorých kvalita a kvantita stravy (najmä pri rodinných oslavách) hrala jednu z najvážnejších rolí. Svadobné hostiny sa presunuli zo svadobných domov do priestoru kultúrneho domu, čím došlo k narušeniu tradičného scenára svadobného obradu.

Úroveň kulinárnej kultúry $\mathrm{v}$ dedinskom prostredí na Spiši v druhej polovici 80. rokov 20. storočia sprostredkovala etnografka M. Ušaková v kapitole venovanej strave v monografii L’ud hornádskej doliny: „....Napriek tomu, že strava je jednou z najkonzervatívnejších zložiek kultúry, zaznamenala $v$ skúmaných obciach za posledných štyridsat' rokov vel'ké zmeny, ktoré vznikli pod vplyvom ekonomicko-sociálnych premien v období budovania socializmu. (...) Hlavný podiel na zmenách majú ženy, ktoré sú väčšinou zamestnané. Odchádzajú ráno do zamestnania a vracajú sa domov až popoludní. Deti sa stravujú v školských jedálňach a muži obedujú v závodnej jedálni alebo až doma neskoro popoludní. K spoločnému stolu sa sadá už iba v nedelu a vo sviatočné dni. Stôl je prikrytý vo všedné dni igelitovým obrusom, v nedel'u sa dáva textilný obrus. Vo všedný deň sa na stôl rozkladajú taniere a lyžice, do stredu sa položí nádoba s jedlom. Na taniere rozdel'uje jedlo žena. Vel'ký dôraz sa začína klást' na kultúru stolovania, najmä v nedel'u a vo sviatok sa prestiera plytký i hlboký tanier s príborom. Hlavne v mladých domácnostiach sa dbá na stolovanie, aby ich deti vedeli správne jest' a neboli zaskočené pri spoločnom stravovaní v školských družinách, na rekreáciách a pod... Raňajky pozostávajú obyčajne z prevareného mlieka, bielej kávy alebo kakaa a omasteného chleba so salámou, syrom alebo pečiva. Väčšina členov domácnos- 
ti obeduje mimo domu. Staršíl l’udia si varia na obed tradičné polievky. Na večeru sa pripravujú oblúbené tradičné jedlá - pirohy, halušky, zemiakové jedlá a často i mäso. (...) V nedel'u na raňajky je to podobné. Na obed sa varí mäsová, najčastejšie hovädzia polievka s domácimi rezancami. Ako druhé jedlo sa podáva vždy mäso a zemiaky. Najčastejšie sú to bravčové rezne, vyprážané alebo pečené kura, pečená kačica. K mäsu sa podávajú varené mastené zemiaky, zemiakový šalát alebo ryža. Po obede sa podáva domáci koláč alebo zákusky. Večerajú sa zoyšky od obeda. (...) S postupným zoyšovaním váhy chovaných ošípaných rodiny si nechávajú viacej čerstvého mäsa na spotrebu a novinkou je okrem tradičného údenia mäsa aj jeho nakladanie a sterilizovanie do sklenených pohárov a plechových konzerv. Tento spôsob konzervovania je vel'mi obl'úbený, pretože mäso je po otvorení konzervy hned' vhodné na konzumáciu a čo sa spraví doma, je aj lacnejšie, než kupované výrobky. (...) Spotreba mäsa je podstatne vyššia ako v minulosti a zmenil a obohatil sa jedálny lístok a receptár pokrmov o mäsá pečené, dusené, vyprážané, grilované. Mäso sa stalo takmer každodenným pokrmom. (...) Dodnes sa neudomácnilo používanie kupovaných rastlinných olejov, stále sa preferuje domáca mast' zo zabíjačiek. (...) Spotreba vajec je pokrytá vlastným chovom sliepok. (...) Mlieko a mliečne výrobky sú stálou súčastou jedálneho lístka, kupujú sa $v$ obchodoch a sú rozšírené o rôzne druhy syra, jogurtov a detských mliečnych výrobkov. (...) V súčasnosti sa pripravujú aj francúzske zemiaky a hranolky, ktorých príprava sa udomácňuje najmä v mladých rodinách. (...) Obchody so zeleninou a ovocím ponúkajú nielen naše ovocie, ale aj južné ovocie - citróny, pomaranče, mandarínky a banány. (...) Zaváranie ovocia vo forme kompótov a sterilizovanie uhoriek a čalamády z kapusty je novšou záležitostou. V súčasnosti si gazdiné vyrábajú kompóty z jablk, sliviek, hrušiek a ríbezlí, zavárajú lesné ovocie - maliny a čučoriedky. Výrobu domácich kompótov umožňuje neobmedzená spotreba cukru. (...) V každej domácnosti je už zavedený vodovod. (...) Zrnková čierna káva sa začala pit’ až po 2. svetovej vojne a dnes je samozrejmost'ou, že hostovi sa v dome ponúkne čierna káva. (...) Sortiment nápojov je rozšírený aj o rôzne nealkoholické nápoje - malinovky, džúsy, kupované čaje a rôzne alkoholické nápoje. Vel'kej obl’ube sa teší domáce víno z ríbezlí. (...) 
Dnes sa domácnosti už nezásobujú potravinami na dlhý čas, socialistický obchod zásobuje l'udí pravidelne všetkými druhmi potravín v každom ročnom období. Uskladňovacie priestory $v$ modernom dome zaberajú už menšiu plochu ako v minulosti.

$V$ súčasnosti sa svadby slávia v sobotu a trvajú do nedelného rána. Pretroáva zoyk prispiet' svadobným rodinám na koláče, zákusky a torty potravinami. Príbuzní, susedia, známi nosia múku, cukor, vajcia, maslo, džemy, hrozienka, toaroh, čokoládu, kakao. Na prípravu zákuskov a tort pozývajú rodiny cukrára. Ked’že dnes je pravidlom, že svadobné hostiny sa konajú v reštauráciách a hoteloch, rodiny mladomanželov zabezpečujú len zákusky, jednoduchšie jedlá pre prichádzajúcich svadobčanov pred sobášom a alkoholické nápoje. Svadobné menu býva takmer vždy rovnaké. Po prípitku sa podáva predjedlo - šunka s chrenom alebo obložené vajce. Nasleduje hovädzia polievka s rezancami, vyprážaný rezeň so zemiakmi a uhorkou. Okolo 22. - 23. hodiny sa podáva najčastejšie hovädzie dusené mäso s ryžou. Po polnoci sa ponúka pečené bravčové mäso s kapustou a knedl'ou. Medzitým sa hostia ponúkajú zákuskami, kávou a nápojmi. (...) Narodenie dietata a krst sú dnes velkou rodinnou udalost’ou a slávia sa domácou hostinou. (...) V súčasnosti sa kar uskutočňuje v reštauráciách, kam prichádzajú príbuzní a známi rovno z cintorína. Podáva sa slávnostný obed, zvyčajne hovädzia polievka, vyprážaný rezeň so zemiakmi a zákusok. (...) Vianočné sviatky sa oproti minulosti zmenili iba v tom, že dnes sa vedl’a tradičných jedál (oblátka s medom a cesnakom, kapustová polievka s hríbmi a mäsom, strukovinová polievka, lokše s makom, sušené slivky, koláče a hriata pálenka) na Štedrú večeru pripravuje aj vyprážaný kapor s majonézovým zemiakovým šalátom a stôl je obohatený o nové druhy ovocia - banány a pomaranče a zákusky. (...) Velkonočný jedálny lístok (vajíčka, šunka, klobása, huspenina, chlieb, vel'konočné koláče) sa oproti minulosti takmer nezmenil a zvyky s ním spojené takisto pretrvávajú“ (Ušaková: 1989, 85 - 105).

Z etnografických výskumov $M$. Ušakovej v rurálnom prostredí regiónu Spiša v druhej polovici 80. rokov 20. storočia možno sumarizovat:

V stravovacích modeloch obyvatel'stva pretrvávalo samozásobitel'- 
stvo niektorými potravinami (napr. bravčové mäso, mast', vajcia, zemiaky, domáce víno). $\mathrm{V}$ rodinách sa začali praktizovat' nové spôsoby konzervovania mäsa, ovocia a zeleniny sterilizovaním. Jedálny lístok sa rozšíril o nové recepty na úpravu potravín (najmä mäsa, zemiakov, zákuskov). Mäso sa stalo takmer každodenným jedlom. Vo všedné dni rodina jedla zväčša individuálne a v prípade obeda často mimo domu. Najdôležitejším spoločným jedlom rodiny bol nedelný obed. Rozšírené bolo stravovanie obyvatel’stva v predškolských, školských a závodných jedálňach. V obciach bola siet̉ dostatočne zásobovaných predajní potravín. Domy boli napojené na verejný vodovod. Svadobné hostiny a kary sa konali v reštauráciách a hoteloch. Tradičné vianočné menu bolo obohatené o nové druhy jedál (vyprážaný kapor s majonézovým šalátom, exotické ovocie, zákusky).

Na rozdiel od dietologického výskumu, ktorý sa konal na celoslovenskej úrovni a sledoval výživu vo všetkých sociálnych skupinách obyvatel'stva, etnografické výskumy zamerané na úroveň stravovania ludí v čase socializmu mali iný charakter. Výskumy boli zamerané regionálne (Horehronie, Spiš) alebo lokálne (Závadka nad Hronom, Láb, Vel'ké Zálužice, Žakarovce, Sebechleby) a väčšinou v rámci väčších výskumných projektov, najmä ako časti etnografických monografií. Až pri písaní tejto práce sa ukázalo, že etnografických podkladov $\mathrm{k}$ problematike stravovania počas socializmu je pomerne málo. Popri niekolkých pokusoch o mapovanie socialistického spôsobu života l’udí slovenská etnografia sa vo väčšine svojich výskumných projektov zamerala na tradičnú kultúru predsocialistického obdobia, sústred’ujúc sa takmer výlučne na dedinské prostredie. Aj jediný celoslovenský etnografický výskum, realizovaný v rokoch 1971 - 1975 pre potreby Etnografického atlasu Slovenska, sa zaoberal výlučne problematikou tradičnej vidieckej kultúry. Napriek týmto faktom sa však dá povedat', že relevantné etnografické lokálne a regionálne materiály $\mathrm{k}$ problematike stravovania l'udí na Slovensku v rôznych fázach socializmu v mnohých prípadoch potvrdili alebo detailnejšie doplnili dietologické výskumy. 


\section{PREDAJ POTRAVÍN}

Predaj potravín na Slovensku do politického prevratu v roku 1948 mal živnostenský charakter. V mestách fungovali súkromné predajne so zmiešaným tovarom, ako aj špecializované predajne chleba a pečiva, mäsa a údenárskych výrobkov, mlieka a mliečnych výrobkov, delikates a pod. Zelenina, ovocie, hydina, vajíčka, smotana, tvaroh sa zvyčajne kupovali na mestských trhoch, kde ich ponúkali l'udia z okolitých dedín, prípadne ich dedinské ženy donášali priamo na objednávku do mestských domácností. V dedinskom prostredí s riedkou siet’ou predajní prevažovali predajne so zmiešaným tovarom, kde sa dali kúpitł potraviny, ktoré si súkromne hospodáriaci rol’níci nedokázali sami zadovážit’ zo svojho chovu zvierat alebo z úrody na poliach. Väčšinou to boli sol', cukor, koreniny, cukrovinky, alkohol a do domácnosti potrebný petrolej a zápalky. Na vidieku tiež fungoval podomový obchod, ked’ z prosperujúcich obcí južného Slovenska, kde sa vypestoval prebytok ovocia a zeleniny, prichádzali do horských a podhorských regiónov obchodníci $\mathrm{s}$ týmto tovarom na vozoch. Inak boli vidiečania odkázaní na samozásobitel'stvo potravinami, ktoré v mnohých, najmä horských regiónoch spôsobovalo vo výžive l’udí problémy najmä s jej pestrostou a vyváženostou.

To všetko viedlo socialistických modernizátorov $\mathrm{k}$ rozhodnutiu zmenit’ pomery v potravinových obchodoch a najmä zlepšit zásobovanie potravinami na dedinách. Znárodnením súkromných potravinových obchodov vznikla na Slovensku siet’ spotrebných družstiev JEDNOTA - národný podnik. Najskôr to boli obchody s pultovým tovarom, postupne sa otvárali tzv. samoobsluhy. Prvou takou na Slovensku bola predajňa TETA na Dunajskej ulici v Bratislave, otvorená roku 1960. Okrem toho sa potraviny nakupovali v špecializova- 


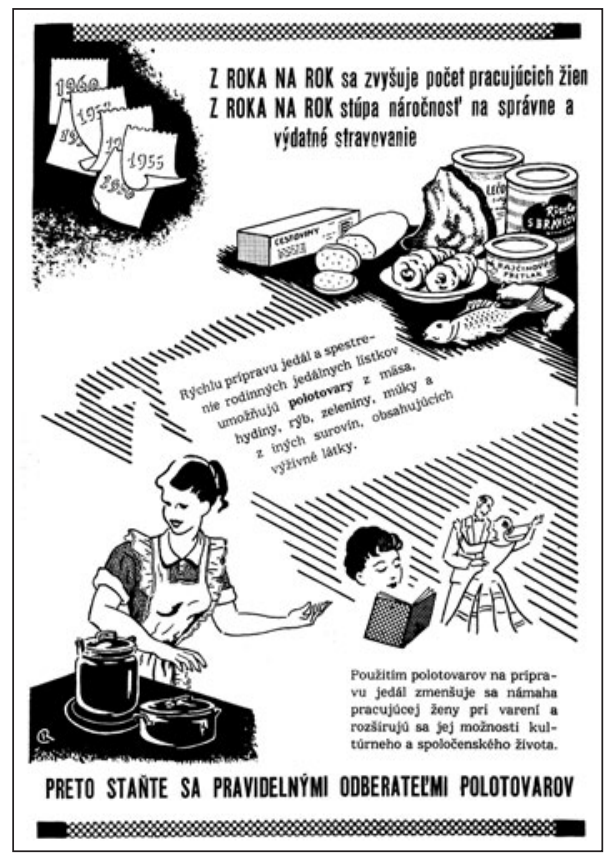

ných predajniach: CHLIEB A PEČIVO, MLIEKAREŇ, ZELENINA A OVOCIE, MÄSO - ÚDENINY, SYRY, RYBY, upravené potraviny $\mathrm{v}$ POLOTOVAROCH, mrazené v MRAZENÝCH VÝROBKOCH a delikatesy v LAHÔDKACH. Boli zavedené POJAZDNÉ PREDAJNE, ktoré v určitý deň a čas dovážali základné potraviny do odlahlých dedín a osád. Len na východnom Slovensku bolo na tieto služby odkázaných 50000 l’udí. Väčšina obchodov zatvárala vo všedné dni o 18. hodine, čo nevyhovovalo l'ud'om, ktorí pracovali dlhšie alebo mali d’aleko z práce do obchodu. Preto sa postupne najmä vo väčších mestách otvárali VEČIERKY, ktoré mali otvorené do 22. hodiny. Potravinové obchody boli otvorené aj v sobotu doobeda, v nedel'u boli všetky zatvorené (Pražská - Jindra: 2002, 58).

Socialistickí ideológovia vyhlasovali, že $\mathrm{v}$ tomto politickom zriadení výroba a distribúcia potravín je podmienená a riadená 
potrebami širokých más l’udu. Centralizovaný plánovaný systém riadenia však nedokázal splnit tieto proklamácie, čo spôsobovalo, že v obchodnej sieti nebol vždy pre všetky skupiny obyvatel'stva dostupný kvantitatívne alebo kvalitatívne vyhovujúci sortiment potravín. Existovali potraviny, ktoré boli nedostatkové. Týkalo sa to aj domácej produkcie, napríklad mäsových výrobkov, ako aj importovaných potravín zo štátov mimo socialistického tábora, napríklad južného ovocia, kvalitného kakaa, kávy, čokolády, alkoholu a pod. „...Podl'a socialistickej propagandy na Západe žili kapitalisti a robotníci tam biedne živorili. U nás všetko kvitlo, všade sa prekračoval plán. Nešlo mi do hlavy, ked' sa máme tak dobre, prečo sú na všetko fronty. Stálo sa na pomaranče, banány i na ihly do šijacieho stroja. Pri spomienke na tieto fronty si uvedomujem, že v nich stáli len ženy..." (Šebo: 2010, 15). „....Kto nenakupoval za socializmu, nepozná ozajstnú radost’ z nákupu. Kedysi to bolo skvelé dobrodružstvo, nadšenie a adrenalín súčasne. Pocit, ked' sa človek vracal domov s mandarínkami, Atou a, nedabojže, s hajzlákom, sa nedá opísat'..." (Šebo: 2008, 149). „...Ako výsmech l’ud’om, ktorí mali neustále problémy s nakupovaním potravín, vyznieval televízny seriál Žena za pultom. Nakrúcal sa v časoch, ked' sa stáli fronty na banány a pred mäsiarstvom a poobede už väčšinou neboli ani rožky. Bol to seriál ,zo súčasnosti', z vel'kopredajne potravín..." (Šebo: 2009, 310 - 311).

Potravinársky (ale aj iný) tovar zo zahraničia alebo naše výrobky určené na export boli však dostupné v predajniach podniku zahraničného obchodu TUZEX, kde ich bolo možné nakupovat’ za tzv. bony, ktoré sa získavali výmenou za cudzie meny, napríklad americké alebo kanadské doláre, nemeckú marku, švajčiarske alebo francúzske franky. Tento luxusnejší tovar bol dostupný občanom, ktorí mali možnost’ získat’ valuty prostredníctvom svojich príbuzných žijúcich $\mathrm{v}$ zahraničí, prípadne formou dôchodku za prácu v zahraničí. Osoby bez takýchto možností získavali bony nelegálnym spôsobom od ich priekupníkov, tzv. vekslákov, priamo na ulici pred predajňami Tuzexu. Pred týmito špecializovanými predajňami stávali najmä pred sviatkami dlhé rady ludí, ktorí si chceli kúpił’ aspoň niektoré nedostatkové potraviny, najmä alkoholické nápoje, 
kvalitnú čokoládu, holandské kakao, instantnú kávu, Ovomaltinu, kečup Heinz, žuvačky Wrigleys a pod.

Pre skupinu socialistickej straníckej a štátnej elity existovala aj možnost’ nákupu luxusnejších potravín v dobre zásobovaných tzv. diplomatických predajniach, kde sa nakupovalo za československé koruny a tovar v nich bol pomerne lacný. L'udia, ktorí mohli nakupovat' v Tuzexe alebo v diplomatickej predajni, boli spoločnost’ou vnímaní ako privilegovaná skupina s vyšším hmotným i sociálnym kapitálom (Zajonc: 2006, 192 - 193).

Potraviny v období socializmu možno rozdelit do troch kategórií: 1. na potraviny, ktoré boli; 2. potraviny, ktoré boli občas, a 3. potraviny, ktoré neboli. Na potraviny bola tzv. záporná daň z obratu, to znamená, že mali byt' lacné a dostupné každému (www. ceskatelevize/porady/retro). Životná realita mnohých ludí však bola iná, pretože úroveň stravy $\mathrm{v}$ mnohých domácnostiach negatívne ovplyvňoval aj typický socialistický ekonomický fenomén - dlhodobé sporenie domácností na automobil, motocykel, elektrospotrebiče, byt a pod., ktoré boli v Československu vzhl’adom na zárobky cenove vel'mi náročné (Franc: 2003, 169 - 183) a usporit’ sa dalo len na jedle a ošatení. 


\section{ALTERNATÍVNE ZDROJE STRAVY}

Pri nedostatočnom zásobovaní potravinami boli l'udia nútení hladat’ si iné zdroje a snažili sa dopíňat’ svoj jedálny lístok predovšetkým formou tzv. samozásobitel'stva. Samozásobitel'stvo potravinami v období socializmu nemožno však chápat’ rovnako ako v predchádzajúcich historických obdobiach, ked' rol'nícke hospodárstvo zásobovalo rodinu všetkými podstatnými potravinovými článkami a ich vel'ká čast' bola spracovaná po domácky alebo v miestnych zariadeniach, ako boli mlyny, pekárne, mäsiarstva a pod. V období socializmu išlo skôr o domácku produkciu potravín alebo potraviny získané darom alebo výmenou (Dvořáková-Janů: 1999, 173, 147), ktorými sa dopĺňali alebo nahradzovali kupované potraviny.

V ére socializmu bola takáto podnikavost' nevyhnutná ako „plátanie dier" spôsobených nedostatkom oficiálnej ekonomiky. Výroba potravín v rodinách sa však bežne realizovala popri inom zamestnaní, a tak v proklamovanej homogenizovanej socialistickej spoločnosti sa na základe existencie či neexistencie domáceho hospodárstva vyskytovali tri základné typy rodín: rodina samozásobitel', rodina podnikatel' a rodina užívatel'. Ich spoločným znakom bolo, že členovia rodiny boli zamestnaní zároveň v štátnom sektore. $Z$ výskumov z roku 1984 vyplynulo, že až 70 \% obyvatel'stva malo ešte domáce hospodárstvo a jedna desatina z neho aj predávala svoje výrobky. Vlastníctvo záhrady a pôdy bolo na Slovensku významným ekonomickým faktorom a dôležitou "sociálnou poistkou“ aj v ekonomických podmienkach socializmu. Skúsenost’ dvojitého zamestnania bola jednou z dôležitých stratégií riešenia osobnej situácie l’udí (Radičová: 1993, 406).

Na dedinách išlo pravdepodobne o zvláštnu previazanost' tradície, spoločenských vzt’ahov a tlakov, pretože vidiečania boli vždy 
silno integrovaní do siete sociálnych vztahov (príbuzenských, susedských, spolkárskych a pod.) a rozsiahlych väzieb vzájomnej recipročnej závislosti. Rôzne pozície, šance a hodnotenia sa vo vidieckej spoločnosti získavali formou určitej konformity. Tou bola výmena práce a naturálií, darov, protislužieb, ktoré boli produktom dlhodobých procesov vzájomnosti. A tak aj „socialistické“ samozásobitel'stvo bolo angažovanou činnostou l’udí, ktorá zahrnovala rad d’alších významov a mechanizmov, akými boli napríklad: domáce potraviny ako ekonomická poistka rodiny, zdravotná neškodnost’ domácich potravín, vzt’ah l'udí k pôde - zemitost', sociálna kontrola dediny a prestíž rodiny, absencia obchodov a možnosti nákupu, ale i relaxácia $\mathrm{v}$ prírode, prvky zábavy, sebarealizácia a radosṫ z dosiahnutej produkcie potravín. Zabezpečenie si potravín v ére socializmu bolo tiež považované „za malé privátne štastie“, ktoré bolo pre mnohých obyvatel'ov- a nielen z vidieka - považované za najdôležitejšiu vec života, obmedzujúceho sa na malý sociálny priestor a jeho vylepšovanie. Práca v záhrade alebo na poli sa považovala za model „zmysluplného“ života (Dvořáková-Janů: 1999, 171 - 172).

Samozásobitel'stvo rodín potravinami v období socializmu potvrdili aj dobové etnografické výskumy. V hontianskej obci Sebechleby sa výskum realizoval v rokoch 1976 - 1980 ako úloha Štátneho plánu základného výskumu pod názvom L'udová kultúra $v$ podmienkach socialistickej spoločnosti. E. Drábiková vo svojej sonde o socialistickej polnohospodárskej výrobe a jej vplyve na spoločenské a kultúrne procesy konštatovala: „Zo začiatku sa kolektíonemu družstevnému hospodáreniu stavali prekážky vyplývajúce z neznalosti riadiacej a organizátorskej práce. (...) Riadenie družstva ovplyvňovali tradičné susedské vzt'ahy a výsledky družstva ohrozoval vžitý konzervativizmus. (...) Nízka produktivita práce a odčerpávanie naturálií, ktorými sa vyplácali pracovníci za prácu, odčerpávali značnú čast' príjmov družstva. (...) Družstevníkom bolo umožnené pracovat’ na vlastnom polhektárovom pozemku - záhumienku, ktorí ho však často uprednostňovali pred prácou na družstve. Z tohto obdobia sa v obci zachovalo aj porekadlo: Chudobné družstvo - bohatí družstevníci!“ (Drábiková: 1896, 15 - 23). 
Rol’nícko-družstevné právo kvalifikovalo záhumienkové hospodárstvo ako menšiu výmeru polnohospodárskej pôdy spolu so živým a mŕtvym inventárom, ktorý môže člen družstva používat’ na doplnenie svojich osobných potrieb. Príčiny a motívy pridelovania záhumienkov družstevníkom boli hlavne psychologické a ekonomické. Ked' sa takto umožnilo družstevníkom uspokojit’ "hlad“ po vlastnej pôde, lahšie sa dalo presvedčit' l'udí, aby vstúpili do družstva a odovzdali svoje agrárne hospodárstva do kolektívneho používania. Ekonomickou podstatou záhumienkov bolo umožnit’ družstevníkom dopestovat’ a dochovat’ si polnohospodárske produkty pre vlastnú spotrebu a odbremenit tak požiadavky iného obyvatel'stva na zásobovanie potravinami (Štefanovič a kol.: 1979, 163). Podobné výhody poskytovali svojim pracovníkom aj štátne pol'nohospodárske majetky na okrajoch svojich pozemkov.

Ako sa tento proces akéhosi medzistupňa medzi individuálnou kapitalistickou formou hospodárenia a novou socialistickou kolektívnou formou premietal do života socialistickej dediny, sledovala vo svojich výskumoch etnografka E. Drábiková v šiestich lokalitách Slovenska (Dolná Poruba, Prochot', Vel'ké Zalužice, Myslava, Láb, Rača). Vo svojej analýze upozornila, že vlastníctvo záhumienkov na Slovensku malo rozdielnu mieru výhod a obmedzení nielen v regionálnom, ale i v lokálnom meradle. Rozmanitost' pol'nohospodárskej výroby na JRD ovplyvňovala aj rozdiely vo vývine a náplni záhumienkového hospodárstva. Obsah jeho produkcie vychádzal z lokálnych výrobných tradícií a postupne sa od nich odchyloval úmerne $\mathrm{s}$ dosiahnutým stavom družstevného hospodárenia. $\mathrm{V}$ počiatočnej fáze, najmä v 50. rokoch 20. storočia, mali záhumienky saturovat’ nedostatkové potraviny. Dôležitou zložkou záhumienkového hospodárenia už od jeho začiatku bol chov domácich zvierat. Najväčší význam dosahoval v prvých rokoch kolektivizácie pol'nohospodárstva, ked' chov kravy bol zábezpekou výživy a odchov tel’ata znamenal mimoriadny finančný príjem pre rodinu. Kravy si rodiny chovali najmä pre mlieko a zásoby hnoja. V podhorských terénoch, najmä v lokalitách s tradičným ovčiarstvom, sa držali pri záhumien- 
koch 2 - 3 ovce predovšetkým na mäso do domácich údenín. Vysoký význam mal chov ošípaných. V domácnostiach družstevníkov sa stalo zvykom chovat' jedného brava pre vlastnú potrebu a d’alšieho na predaj. V rámci drobnochovatel'stva bol bežný chov hydiny, králikov a v lokalitách s ovocinársko-včelárskou tradíciou aj chov včiel.

Postupne, ked' JRD dosiahli vyššiu produkčnú úroveň, na poliach i záhumienkoch sa začali pestovat’ monokultúry. Nastal odklon od pestovania tradičných plodín s výnimkou špeciálnych a ekonomicky výhodných plodín, akými boli vinič, niektoré druhy ovocia alebo zeleniny. Spomína na to predseda družstva v Pate: „...V pareniskách sme pestovali planty koreňovej papriky a inej zeleniny na výsadbu do pol'a. Po výsadbe sa celé pole rozdelilo na riadky, ktoré sa pridelili na osobné obrábanie členom JRD. Tí sa o ne so svojimi rodinami starali väčšinou po sobotách a nedeliach po celé vegetačné obdobie. Najdôležitejšou fázou pestovania koreňovej papriky bol zber plodov. Dedinčania mu dali prívlastok ,salámové hody'. Názov mal pôvod v tom, že počas zberu, na ktorom sa okrem rodiny zúčastňovali aj jej priatelia a známi, sa všetci živili salámou a chlebom, ked'že sa pracovalo celý deň a nebol čas odíst' domov najest' sa."

Záhumienkové hospodárenie už od svojho počiatku vytváralo platformu na realizáciu individuálnych ekonomických zámerov, uskutočňovaných v najužšej výrobnej jednotke - rodine, ale aj na premenu orientácie samostatného rol'níka v uvedomelého stúpenca socialistickej polnohospodárskej vel'kovýroby. V premenách sociálnej situácie menilo sa aj poslanie záhumienkového hospodárenia z prameňa relatívnej existenčnej istoty na činnost̉ zo záluby, z faktora hospodárskej súdržnosti rodiny na príčinu medzigeneračného názorového odstupu, sprevádzajúceho vznik nového socioprofesionálneho profilu dediny. Zavŕšením vývinu malorolníckej doplnkovej výroby v družstevných podmienkach mala byt' etapa bezzáhumienkového hospodárenia. Mala sa začat’ vytvorením vel'kovýrobných družstevných podnikov a podstatou jeho zásad bolo poskytnút' členov JRD možnost’ odkúpit’ si z produkcie družstva pol'nohospodárske produkty za výhodnú cenu na chov hospodárskych zvierat, prípadne osobnú spotrebu. Ciel'om malo byt' odbre- 
menenie družstevníka od zbytočnej pracovnej zátaže, sústredit ho plne na družstevné úlohy a vytvorit’ podmienky na jeho účast’ na verejnom dianí. Táto vízia sa však až do konca socialistického režimu nenaplnila.

Píšu o tom etnografi, ktorí to skúmali v prostredí slovenského vidieka. Napríklad J. Kandert zo svojich výskumov stredoslovenských obcí v 60. - 80. rokov 20. storočia konštatoval: „V sedemdesiatych rokoch, ked'sa v tlači neustále diskutoval problém možného svetového vojnového konfliktu, argumentovali niektorí dedinčania aj skúsenost'ami z 2. svetovej vojny: na dedine je l'ahšie zohnat' potrebné potraviny pre prežitie a nazhromaždit’ nejaké zásoby než v meste. Vždy ale doplňovali, že $v$ takomto prípade by sa museli vrátit $k$ samozásobitel'skému systému, ktorý v tom čase už na dedinách takmer nejestvoval, pretože sa takmer všetko dalo kúpit’ v obchode. Zároveň ironicky doplňali, že je l'ahké žit'v meste, ked' má niekto ,špajzu' na dedine. Tým narážali na rozšírený zoyk proej generácie mestských obyvatel’ov jazdit' si k rodičom či súrodencom na dedinu pre zásoby. Takéto nedel'né návštevy , mladých' boli po dedinách bežné" (Kandert: 2004, 67).

Podobne o tom píše E. Drábiková. Ešte v polovici 80. rokov 20. storočia fungovalo záhumienkové hospodárenie a najmä starší vidiečania považovali túto činnost’ stále za nevyhnutnú životnú potrebu, ktorú realizovali najmä v záujme svojich detí a vnúčat. Dorobené potravinové produkty predstavovali príspevok $\mathrm{k}$ zlepšeniu úrovne ich stravovania, finančné prostriedky z predaja sa zasa využívali ako investície na výstavbu domov, kúpu bytov či auta. „...Dnes je všeobecne rozšíreným javom, že dospelé deti žijúce v meste sa pravidelne na víkendy vracajú do rodičovského domu. Zúčastňujú sa tu na práci i na jej výsledkoch. (...) Starí rodičia im tu s hrdost'ou predkladajú výrobky zo zakál'ačiek, vykŕmenej hydiny, čerstvé ovocie a zeleninu, na rodinné oslavy poskytujú nimi dorobené nápoje. Návštevy zásobujú potravinami aj na celý d’alší týždeň. Kolóny áut tzv. špajziarov, smerujúcich z vidieka do miest, sú typickým nedelným javom na našich cestách" (Drábiková: $1985,350-361)$.

Tento pohlad do slovenských pomerov v tzv. záhumienkovom 
hospodárení potvrdil aj etnografický výskum na lokálnej úrovni v Sebechleboch, kde zásobovanie obyvatel'ov potravinami z vlastných zdrojov v čase výskumu bolo skutočne značné. Napomáhali tomu miestne podmienky: súkromné vlastníctvo záhrad, záhumienkov, vinohradov, spôsob bývania umožňujúci chov zvierat na hospodárskych dvoroch, vyplácanie družstevníkov naturáliami, ktorými kŕmili domáce hospodárske zvieratá... „Domácnosti vlastnia niekol'koárový pozemok, na ktorom sa pestujú základné druhy zeleniny, ovocia, zemiaky, prípadne kŕmne plodiny. Ich produkcia pokrýva spotrebu najmä v letných a jesenných mesiacoch. Na zimné obdobie sa domácnosti zásobujú zemiakmi z JRD, v priemere 2 - 4 q na jednu rodinu. (...) Okrem pozemkov $v$ dedine vlastnia rodiny aj vinohrady $v$ extraviláne, $k d e$ pestujú vinič samorodý, z ktorého vyrábajú víno pre vlastnú spotrebu, ale aj na predaj, z ktorého plynú pre rodinu finančné príjmy. Okrem vína dorábajú si obyvatelia dediny aj iné alkoholické nápoje - hruškovicu, slivovicu, jablkovicu... Z hospodárskych zvierat sa v domácnostiach chovajú ošípané, králiky a hydina. Ošípané v jesennom alebo zimnom čase zabijú a ich mäso spracujú viacerými spôsobmi. Čast' mäsa, stehná a rebrá, sa nasolí a vyúdi. Väčšina mäsa sa však konzervuje ako bravčové vo vlastnej štave a domáce konzervy vystačia zvyčajne až do d’alšej zabíjačky. Do zásoby sa tiež údia klobásy. Čerstvé mäso zo zabijačky sa konzumuje ihned' alebo sa dá zamrazit’ do chladničiek. $V$ rodinách býva zaužívaným zoykom, že sa zabijačky plánujú tak, aby bol zabezpečený prísun čerstvého mäsa čo najdlhšie obdobie. Robí sa to tak, že rodina, ktorá zabíja ošípanú, dáva príbuzným asi $3 \mathrm{~kg}$ čerstvého mäsa a čast’ mäsových výrobkov a tí jej to vrátia v termine svojej zabijačky. Králiky sa chovajú vo vel'kom množstve takmer v každej domácnosti. Len čo dorastú do potrebnej hmotnosti, sú častým chodom na jedálnom lístku a akousi, živou konzervou', ak je potrebné narýchlo pripravit’ obed. Z hydiny sa chovajú sliepky, kurčatá, kačice a husi. Hydinu l'udia konzumujú najmä v lete, ked’ je dorastená. Chov sliepok zabezpečuje po celý rok dostatok vajec" (Stoličná: 1986, 116 - 117).

Od 70. rokov 20. storočia začala čast' mestského obyvatel'stva hl'adat' možnosti rekreačného bývania na vidieku a kupovali si tam tzv. chalupy, väčšinou aj so záhradami a sadmi. Takýmto spôsobom sa 
dostali k vlastnej produkcii potravín, väčšinou zeleniny a ovocia, ktorými si dopíňali stravu. Zároveň sa kontaktovali s domácim vidieckym obyvatel'stvom, ktoré im ponúkalo svoje potravinové výrobky na predaj. Názorne o tom hovorí výpoved’ jednej Bratislavčanky: „....V roku 1975 sme si kúpili starý dom na Záhorí, ku ktorému patrila aj záhrada. Boli na nej štyri staršie, ale rodiace stromy, jabloň, dve hrušky, slivka a kríky ríbezlí. Zadnú čast' záhrady, asi $10 x 6$ metrov sme zryl’ovali a urobili polička, kde sme pestovali paradajky, mrkvu, petržlen, kaleráb, ružičkový kel, cukinu, hrach, jahody a záhradné maliny. Úroda nám zoyčajne vystačila celé leto. Niekedy sme mali privel'a cukiny alebo hrušiek, tak sme to rozdávali príbuzným alebo priatelom a často aj domácim susedom, ktorí to používali ako krmivo pre ošípanú. Za to sme od nich dostávali na revanš dva-trikrát cez leto králika alebo vajička. Z ríbezlí robil manžel domáce víno a hrušky a slivky sme tiež zavárali. Okrem toho sme na chalupe často chodili do okolitých lesov na huby, ktoré sme sušili a zavárali, aby sme mali na zimu zásoby. Chalupa bola pre nás relax na čerstvom vzduchu, spojená s pohybom a prácou, a zároveň sme z nej mali aj osoh v podobe zdravých, dnes by sme povedali biopotravín. Podobne na tom bolo vel'a našich priatel'ov a známych, ktorí mali v okolí Bratislavy kúpené chalupy..."

Na okrajoch miest začali v období socializmu vznikat’ alebo sa rozširovat’ záhradkárske osady, ktoré boli organizované Slovenským zväzom záhradkárov. Využívali sa na to pozemky, o ktoré nemali JRD alebo ŠM záujem, a l’udia tak skultivovali zanedbané alebo nevhodné plochy zeme. Ako tieto aktivity l'udí zdokumentovala etnografka E. Drábiková v Trnave počiatkom 80. rokoch 20. storočia, dopyt po pozemkoch bol enormný, preto sa pridel'ovali predovšetkým (pre socialistickú spoločnost') zaslúžilým občanom. V záhradkárskych kolóniách sa vytvárali nové spoločenské väzby založené na rovnakom záujme - dopestovat si ovocie a zeleninu na vlastnú spotrebu, prípadne na predaj na trhu. Prebiehala tam výmena skúseností, organizovali sa spoločenské podujatia - výstavky dopestovaných plodov, spoločenské večery, členovia kolónie boli zapojení do akcie "Z", čo bola socialistická sút’až o skrášlenie svojho okolia (Drábiková: 1982, 473 - 475). V roku 1989 bolo v Československu 
registrovaných viac ako 400000 záhradkárov, ktorí mohli predávat’ prebytky zeleniny a ovocia vo výkupniach alebo na trhoch. Záhradkárstvo tak bolo popri záhradách pri súkromných domoch d’alším dôležitým prvkom, ktorý pomáhal zásobovat’ obyvatel'stvo miest čerstvým ovocím a zeleninou. Vd’aka týmto aktivitám malo možnost' aj obyvatel'stvo slovenských miest kúpit’ si niektoré čerstvé domáce potraviny na trhoch, kde predávali svoju nadprodukciu rol'níci alebo záhradkári. Išlo väčšinou o ovocie a zeleninu, v menšom rozsahu o hydinu, vo vinárskych oblastiach aj o domáce víno.

Samozásobitel'stvo bolo na slovenskom vidieku a v menších agrárnych mestách dlhé historické obdobia pred érou socializmu hlavným spôsobom zabezpečenia čo najširšieho sortimentu potravín. V socializme sa ich sortiment zúžil a zmenila sa aj škála pokrmov pripravovaných z domácich potravín. Typickým príkladom bol napríklad zánik domácej produkcie chleba, masla, oleja a pod. Na druhej strane sa začali pri domácom spracovaní potravín využívat' nové súdobé poznatky, ktoré sa používali v potravinárskom priemysle. Ako príklad možno uviest’ postupy a produkty späté so zabíjačkou. Okrem tradičných spôsobov konzervovania mäsa solením a údením používali sa v domácnostiach aj nové techniky konzervovania, ako napríklad užívanie tzv. rýchlosoli, konzervovanie mäsa sterilizovaním v sklených pohároch alebo v plechových konzervách. Obliuba domácich klobás spolu s možnostou kúpit črevá a mäso aj nad rámec množstva získaného pri domácej zabíjačke viedli $\mathrm{k}$ tomu, že ich výroba nemusela byt’ vždy spojená so zabíjačkou a klobásy si začali robit ludia aj v mestách. Do sortimentu domácich výrobkov sa dostala aj šunka, ktorá sa vyrábala podobne ako v priemysle pri použití zväčša podomácky vyrobených zariadení (Zajonc: 2006, 191 - 192).

Domáce potraviny mali u l'udí za socializmu stále vysoký status, všeobecne boli považované za kvalitnejšie ako tie, ktoré ponúkali obchody. Preto si l'udia hl'adali rôzne možnosti, ako si takéto potraviny zabezpečit'. 


\section{SOCIALISTICKÉ FORMY VEREJNÉHO STRAVOVANIA}

Odborníci na výživu v čase budovania socializmu propagovali nielen zdravé a racionálne potraviny, ale zároveň apelovali na to, aby sa zásadne zmenili spôsoby stravovania socialistického človeka. Podla ich názoru socialistická žena, ktorá bola zapojená do pracovného procesu, sa mala čo najviac odbremenit’ od práce v kuchyni a prenechat' vel'kú čast' výživy rodiny na zariadenia verejného stravovania. Budovanie verejného stravovania sa dostalo aj do politického programu KSČ. „...Nedávno uverejnený návrh smerníc ÚV KSČ pre zostavenie II. pätročného plánu rozvoja národného hospodárstva ČSR na roky 1956 - 1960 ukazuje, akým búrlivým rozvojom prechádza hospodárstvo najmä na Slovensku, kde sa má zvýšit' výroba priemyslu o 61,5\%. (...) Z tohto hl'adiska je jasné, že verejné stravovanie má velmi dôležité miesto (...) pretože je dôležitým nástrojom nášho hospodárskeho systému pri uskutočňovaní politiky strany a vlády. (...) V najbližšich troch rokoch má verejné stravovanie vzrást' oproti roku 1955 najmenej o 21,5% $v$ štátnom obchode a o 26,5\% u spotrebných družstiev. (...) Verejné stravovanie musí íst' líniou neustáleho zvyšovania výroby pokrmov. Znamená to najmä na Slovensku vyhlásit’ boj proti širokému predaju alkoholu, znamená to prestavat' hostince na reštauračné závody, pretože socialistické pohostinstvo na Slovensku prebralo po súkromných podnikateloch závody malé, zanedbané, zväčša zamerané na predaj alkoholu“ (Jirges: 1956, 5).

Najmä závodné, školské a predškolské jedálne sa mali stat’ „výkladnou skriňou" socialistického pokroku - prechodu od individualizmu ku kolektivizmu. Verejné stravovanie bolo centrálne riadené a varilo sa $\mathrm{v}$ ňom podla stanovených noriem technologickej prípravy, hmotnosti i vizáže jedla (Španko: 1957, 17 - 19). 
Realitu takéhoto stravovania si pamätá každý, kto ju prežil. Jedálne boli vybavené unifikovanými umakartovými stoličkami a stolmi pokrytými igelitovými obrusmi, vybavené plechovými táckami na prenášanie jedál a plechovými príbormi. Unifikovane aj páchli tažko identifikovatel'ným „odórom“, v ktorom prerážali najmä zemiaky. Jedlo sa vydávalo cez okienko a podávala ho väčšinou anonymná ruka kuchárky. V takýchto jedálňach sa zvyčajne pripravovalo 12 - 15 jedál dookola, takže približne po dvoch týždňoch prišli na rad tie isté jedlá. Podla noriem mala byt skladba jedál od pondelka do piatka takáto: 1-krát bezmäsité jedlo, 1-krát polomäsité jedlo, 3-krát mäsité jedlo. Častou polievkou bol napríklad bujón so zeleninou a rezancami, prípadne "písmenkami“ - cestovinou v tvare drobných písmen a zapražená paradajková, hrachová, kapustová polievka a pod. Ako bezmäsité jedlá sa varili napríklad parené buchty, buchtičky s krémom, žeml'ovka, grenadír marš, ako polomäsité napríklad rizoto, plnené papriky, ako mäsité varené hovädzie mäso s rôznymi omáčkami, pečené bravčové mäso, fašírky, niekedy kura, podávané väčšinou so zemiakovou kašou, varenými zemiakmi, ryžou alebo knedlami. Z vnútorností boli najčastejšie pl'úcka nakyslo. Špecialitou týchto vývarovní bola tzv. UHO omáčka - univerzálna hnedá omáčka, ktorá sa dodávala z výrobní ako polotovar, zalievalo sa ňou mäso a chutila všade rovnako. K jedlu sa podával zväčša kompót, kyslé uhorky, sporadicky čerstvé ovocie a čaj osladený sirupom (www. ceskatelevize/porady/retro).

Atmosféra v týchto jedálňach bola väčšinou hektická, l’udia sa tlačili s táckami v radoch pred okienkom s jedlom a potom sa snažili vybojovat’ si miesto pri stole. Neraz sa stalo, že stáli s plnou táckou nad hlavou iného jedáka a čakali, kedy už konečne odíde. Výchovnou špecialitou v školských jedálňach bola prax, že „vzácny“ banán alebo pomaranč dostal žiak len vtedy, ked’ dojedol všetko jedlo. Spomína na to aj J. Šebo $(2008,62)$ vo svojej reflexii o živote v socializme: „....Školskú jedáleň som povinne navštevoval osem rokov. Podávané jedlá sa nedali jest', navyše sme boli pod prísnym dohl'adom kuchára, ktorý nás strážil a nútil všetko zjest'. Poniektorí zúfalci vynášali tučné fl'aksne tordého 
mäsa vo vreckách nohavíc..." Podobnú spomienku má aj pani R. M.: „Na Základnej škole som sa stravovala v školskej jedálni. Varili tam nechutné jedlá, ktoré sa mi sprotivili na celý život, napríklad špenát, grenadír marš alebo pl'úcka na smotane. Najhoršia bola však mrkvová omáčka, ktorá bola taká hnusná, že sme ju vylievali z tanierov do zásuviek jedálenských stolov. Viete si predstavit, ako tá jedáleň v ten deň vyzerala?"

Inštitúcie, v ktorých neboli vybudované závodné jedálne, predávali svojim pracovníkom odbormi dotované pomerne lacné stravovacie lístky, ktorými sa mohlo platit’ v niektorých reštauráciách.

Zariadenia komerčného verejného stravovania pre obyvatel'stvo boli v socialistickom Československu rozdelené na štyri cenové skupiny:

I. cenová skupina - to boli najlepšie hotely a reštaurácie, kam sa mohlo chodit len $\mathrm{v}$ obleku a s kravatou a žena $\mathrm{v}$ sukni alebo $\mathrm{v}$ šatách. Na niektorých miestach bol aj nápis: „Vstup v texaskách zakázaný!“ Okrem bežných jedál sa podával stroganof, chateaubriand, filé Orly a iné „exkluzívne“ jedlá a ceny neboli pre bežnú klientelu.

II. cenová skupina - to boli reštaurácie s klientelou tzv. slušných ludí. Podávala sa tam poctivá držková alebo gulášová polievka, z varených jedál napr. sviečková na smotane, segedínsky guláš, pečené rebierko, biftek s vajcom či zabíjačkové špeciality. Medzi oblúbené jedlá patrili viedenský rezeň a vyprážaný syr s hranolčekmi a tatárskou omáčkou. Vyprážaný syr patril k najlacnejším jedlám a spolu so sedliackou omeletou bol typickým študentským jedlom.

III. cenovú skupinu tvorila väčšina reštaurácií a pohostinstiev. Personál klamal a kradol, kde sa dalo. Varit’ sa malo podla normy, ale bežne sa to obchádzalo. Výsledkom bolo, že po skončení práce odchádzali pracovníci kuchýň obtažkaní taškami s „ušetrenými“ potravinami. Oblúbeným trikom bola zámena alkoholu, napríklad talianskeho Cinzana za vermut tuzemskej alebo mad’arskej výroby.

Najlacnejšie boli POHOSTINSTVÁ a BUFETY, ktoré boli zaradené do IV. cenovej skupiny. Ich charakteristickým znakom bolo jedenie postojačky a lacný alkohol. Tu sa nedodržiavali žiadne pravidlá. Bola to zlatá baňa pre výčapníkov, ktorí patrili spolu s pumpármi 
a mäsiarmi medzi najbohatších l’udí $\mathrm{v}$ socialistickej spoločnosti. Niektorí štamgasti v týchto podnikoch trávili väčšinu svojho alkoholického života (Šebo: 2010, 68 - 70).

Ako to v nich vyzeralo, výstižne opisuje L. R. na internete:

"Krčma vlastne nie je krčma, ale je nad ňou nápis Pohostinstvo. Je to typická krčma ,na stojáka'. Dostanete v nej nielen pivo, borovičku, vodku či rum, ale aj teplé jedlá. Vychytená je držková polievka s rožkom alebo mad'arský guláš z hovädzieho mäsa s knedlou. Páchne to tu zmesou cigaretového dymu, alkoholu a dychom opilcov a zatuchliny z večne špinavých dlážok, ktoré zamestnanci z času na čas zotrú vodou namiesto toho, aby ich poriadne vydrhli. V krčmách sa vždy pohybovali pochybné indivíduá, ktoré sa vám snažia prihovorit' len preto, aby ste im nechali dopit' pivo, prípadne dojest' polievku..."

Podobne spomína aj I. P. na bufet v Banskej Bystrici oproti pošte: „....Bol to l'udový bufet, kde sa fasovali polievky, držková, gulášová, hovädzia. Jedávali sa tam aj jaternice, zemiakové placky a vajcia našich osloboditelov. To miesto sa vyznačovalo tým, že tam gonokoky plávali vzduchom, mohli ste tam chytit’ aids aj kvapavku, aj všetko možné. Do bufetu chodili aj úradníci, aj Cigáni, hygiena tam nebola bohvieaká. A smrad tam bol z rýb, z pražených údenáčov a kyslých zavináčov. Nikdy som tam nechodil jest', len na borovičku a pivo. Bolo to báječné..." (www. pravda.sk 19. 6. 2012).

V lacnejších cenových kategóriách sa ocitali aj l'ud'mi obl'úbené a hojne navštevované samoobslužné podniky, dnes by sme povedali fastfoody. V Bratislave to bol predovšetkým Mliečny bar, tzv. Mliečak, a Luxorka. Mliečny bar bol vyhl’adávaným miestom. „Neviem, kto vymyslel toto geniálne slovné spojenie. Mne to vždy pripadalo ako kombinácia zdravého mlieka s nezdravým alkoholickým barom. V každom prípade Mliečny bar bol vel'mi obl'úbeným miestom. Dodnes mi chýbajú bryndzové halušky s cmarom, puding s ovocím, jahodový koktail, vtáčie mlieko, šaláty..." (Šebo: 2008, 114).

V Luxorke na prízemí výber jedál nebol vel'ký, ale boli chutné, napríklad sviečková na smotane a guláš s knedlami. Najoblúbenejším dezertom tam boli jahody so šlahačkou. Na druhom konci Štúrovej ulice bola l’udová jedáleň U mäsiarov, kam sa chodilo na 
polievky, špeciálne na držkovú. Počas posledných dvoch dekád socializmu bola lacná a populárna jedáleň Kamzík. Okrem jedál tu predávali aj zákusky a l’udia tam sedávali pred predstavením kina Praha a Pohraničník. Gurmán vedl’a kina Palace, ktoré preslávilo nonstop premietanie krátkych filmov, bol tiež pokusom o socialistický fastfood. Ako prví tam predávali hranolčeky s majonézou. $\mathrm{V}$ centre bol aj bufet Tempo, kde ponúkali okrem iného rôzne klobásky a párky. L'udia vyhl'adávali aj bufet Liptov a Lahôdky pri predajni Teta alebo pod Savoyom.

Kultovým miestom bol v Bratislave Kryštál bar, kde varili povestnú fazul'ovicu, na ktorú sa chodilo najmä v noci pri návrate $\mathrm{z}$ vinární. Známe miesto na rýchle najedenie sa bol Mini Pipi gril oproti Univerzitnej knižnici, kde pripravovali grilované kurčatá a jedlá z hydiny. Stačilo si dat' hustú polievku s mäsom alebo žeml'ovú plnku s drobami, a človek bol nasýtený. Kúsok vyššie bola d’alšia l'udová jedáleň Perlička. Podobná bola Alžbetka. K špeciálnej kategórii stravovacích zariadení patrili predajne Ryba. Tam sa chodilo najmä na majonézový šalát z tresky s čerstvým pečivom. Predávali tam aj iné šaláty na váhu, kyslé a údené ryby (Dyda: 2012). Oblúbené boli aj tzv. diétne jedálne, kde sa dalo lacno najest’ - napríklad Charitas $\mathrm{v}$ Bratislave.

V Košiciach sa l'udia chodili najest' do Gastrodomu, kde sa predávali šaláty, ruské vajcia, šunka v aspiku, alebo do Lahôdok na poschodí obchodného domu Prior. Na grilované kurčatá sa chodilo do Pipigrilu. Na Námestí maratónu mávali zasa vynikajúce palacinky, buchty na pare, dukátové buchtičky so šodó. Na Kováčskej ulici bola reštaurácia Malá fajka, kde sa chodilo na fazul’ovú polievku (www. pravda.sk 19. 6. 2012). Rýchle a lacné stravovacie podniky v ére socializmu mali síce často problematickú hygienu predaja, zato svoju osobitú atmosféru, pretože sa v nich stretávala sociálna zmes l'udí - od politikov, profesorov, umelcov, študentov, úradníkov, robotníkov až po tzv. somrákov, ktorí čakali na zvyšky jedál a nápojov. Úžasne to zobrazil český spisovatel' Bohumil Hrabal vo svojej knihe Automat svět, ktorá vyšla v roku 1966 a neskôr bola aj sfilmovaná. 
Problematickú úroveň socialistického verejného stravovania pripúštali aj odborníci na túto problematiku. „...Naše závody verejného stravovania zatial neuspokojivo plnia svoje poslanie socialistickej spoločnosti. $V$ nedostatočnej miere uplatňujú správne zásady výživy našich pracujúcich. Zanedbávajú otázky hygieny. Vyskytuje sa nemálo prípadov, ktoré svedčia o tom, že sú ešte takí, ktorí chcú žit’ na úkor iných, okrádajú spotrebitelov a dokonca štát poškodzujú o väčšie sumy peňazí..." (Bortel: 1957, 146).

Závan západného štýlu stravovania sa objavil s podnikmi, kde sa grilovali kurčatá, ale predovšetkým s predajom hotdogu, čiže párka v rožku, v 80. rokoch 20. storočia. Predávali sa v špeciálnych stánkoch a l’udia na ne stáli dlhé rady. Podobne sa predávali aj teplé smažené pirôžky plnené lekvárom alebo makom, ktoré západné hotdogy vyvažovali tým, že sa propagovali ako ruské národné jedlo.

„Železná" ideologická opona, ktorá oddel'ovala socialistické štáty od d’alšieho sveta, mala dosah aj na naše stravovanie a gastronómiu. Vel'a vo svete bežných potravín bolo u nás úplne neznámym alebo nedostatkovým artiklom, preto nebolo možné pripravovat’ jedlá svetovej kuchyne tak, ako to bolo za 1. ČSR. Odborníci na výživu hl'adali preto inšpiráciu $\mathrm{v}$ kuchyniach spriatelených národov socialistického bloku, predovšetkým v ZSSR. Na vývine ich predstáv v oblasti hl'adania vhodných medzinárodných vzorov môžeme dobre pozorovat’ aj meniacu sa spoločenskú atmosféru. Kuchyňa národov ZSSR mala predovšetkým nahradit’ silný vplyv rakúskej kuchyne, ktorá bola v našom kultúrnom prostredí prítomná z dôb rakúsko-uhorskej monarchie. Kniga o vkusnoj a zdorovoj pišče z roku 1952 s citátom J. V. Stalina na predsádke, ktorá bola preložená do češtiny pod názvom Jak se vaří v ZSSR, vyšla v roku 1954 a využívala sa ako propaganda prostej a zdravej slovanskej l'udovej stravy. Vydania tejto knihy boli pre sovietske ženy encyklopedickým kuchárskym manuálom, ktorý svojimi didaktickými komentármi, ideologickým kázaním, neoosvieteneckými vedeckými exkurzmi a fotografiami výrobní sovietskych potravín a domáceho hodovania ponúkala kompletný koncept štastného, hojného a kultúrneho 
socialistického života. Varenie, písalo sa v nej, nie je l’ahkovážnou záležitost’ou, varenie predstavuje sebazdokonal'ovanie a skultúrňovanie prostredníctvom kuchynskej práce (Bremzen: 2014, 147). Tzv. sovietska kuchyňa bola však nezmyslom, pretože obsahovala kulinárne tradície viacerých národov: ruského, ukrajinského, gruzínskeho atd'. Až v priebehu 60. rokov 20. storočia bol tento nonsens odborníkmi uvedený na správnu mieru. S tradičnou ruskou kuchyňou mali však tiež problém. Prevažovali v nej totiž kaloricky vel'mi výdatné pokrmy s vysokým podielom tuku, a tiež podiel mäsa v ruskej strave nevyzeral tak, ako si odborníci na výživu predstavovali. Diskutabilné boli aj tradičné pirohy, pelmene alebo bliny z bielej múky. Na druhej strane bola ruská a ukrajinská kuchyňa spájaná s konzumáciou čierneho chleba, preto sa u nás tieto druhy predávali pod názvami „kyjevský“ alebo „moskovský“ chlieb. K vyzdvihovaným pozitívam ruskej kuchyne patrila aj vysoká spotreba zeleniny, prezentovaná najmä tradičnou polievkou boršč, kvasených mliečnych výrobkov - kefíru a jogurtu, tvarohu a vysokého podielu rýb v strave. Oceňovaná bola aj častá konzumácia čaju a nízkoalkoholických kvasov v opozícii k pivu, ktoré bolo u nás najkonzumovanejším nápojom. Ruská kuchyňa mala vzhl’adom na pozíciu Sovietskeho zväzu slúžit našej gastronómii ako výnimočný inšpiračný zdroj. Jej úspech bol umocňovaný najmä dovozom lacných a pritom vo svete drahých potravín, ako bol napríklad kaviár alebo sekt.

Inšpiračné zdroje pre československú gastronómiu sa hladali aj v balkánskych krajinách, najmä v Bulharsku a vo vtedajšej Juhoslávii, kde sa vysoko cenili zeleninové jedlá z paradajok, papriky, patizónov či baklažánov, napríklad lečo, sarma, džuveč, čerstvé zeleninové šaláty, vysoký konzum rýb, spôsob úpravy mäsa na ražni a grile, čo boli hity racionalizátorov stravy v 60 . rokoch 20 . storočia. Menej nadšenia v nich budila vysoká spotreba bieleho chleba.

Z vyspelej mad’arskej kuchyne l’udia u nás bažili za tzv. uhorskou salámou, čabajskou klobásou, tokajskom víne a za ovocnými a zeleninovými výrobkami, napríklad pretlakom z rajčiakovej papriky, ktoré však socialistický trh nebol schopný dodávat' kontinuitne 
a v žiadaných množstvách. Takmer všeobecne sa v našej kuchyni rozšírili typické mad’arské jedlá: guláš, paprikáš, perkelt, plnená paprika, tarhoňa, často však v silno modifikovanej podobe, ktorá mala k originálnemu jedlu d’aleko. Bulharské lečo, mad’arské plnené papriky a ruský boršč boli uvádzané ako príklady pokrmov, ktoré sa rozšírili do našej kuchyne vd’aka zdravému stravovaniu vo verejných jedálňach. Dôležitú rolu v procese internacionalizácie socialistickej kuchyne zohrávali však ekonomické faktory, ked’že mnohé potraviny sa distribuovali a vymieňali za iné komodity v rámci štátov začlenených do Rady vzájomnej hospodárskej pomoci a museli sa v krajine prijímatel’a zužitkovat' (Franc: 2003, 183 - 202).

Inšpirácie hladala československá socialistická gastronómia aj v krajinách tzv. tretieho sveta. Od polovice 50. rokov 20. storočia sa začali v odbornej literatúre objavovat’ články o čínskych stravovacích zvyklostiach. Impulzom pre rozšírenie povedomia o tejto kuchyni a jej propagáciu bolo otvorenie čínskej reštaurácie v Prahe roku 1958, kde niekol’ko rokov varili čínski kuchári. Stala sa výnimočným miestom, kde sa bolo potrebné dopredu objednat’ a hostia v nej mohli zotrvat' len po určitý čas. Varit’ „čínu“ sa stalo módou aj $\mathrm{v}$ domácich pomeroch, no $\mathrm{v}$ akejsi podivnej podobe, kde mäso prevažovalo nad zeleninou a chýbali originálne ingrediencie na dochutenie. Z čínskej kuchyne sa začalo propagovat najmä využitie sóje, ktorá sa pokladala za jedno z východísk z problémov vo výžive ako lacná náhrada bielkovín v strave. Menší ohlas mala indická kuchyňa, ktorá bola pre naše chutové návyky príliš korenená, a tak sa celé jej bohatstvo zredukovalo viac-menej na prípravu jedál s chutou kari a niektorí l’udia sa pokúšali o domácu výrobu ovocno-zeleninových „,̌̌atní". Hospodársku spoluprácu malo socialistické Československo aj s africkou Guineou a Kubou Fidela Castra. Nekvalitné kubánske pomaranče sa stali symbolom nedokonalosti tohto režimu. Aj keby sa zdalo, že z Afriky budeme dovážat' čerstvé južné ovocie, nebolo to tak a väčšina týchto artiklov bola dovážaná v konzervách (www.ceskatelevize/porady/retro; Franc: 2003, 211 - 216).

V období vrcholiacej tzv. studenej vojny medzi socialistickými 
štátmi a Západom akékolvek pozitívne hodnotenie západného životného štýlu bolo nemožné a neobišlo to ani otázky výživy. Znamenalo to ignorovanie aj takých vyspelých gastronomických inštitúcií, ako boli francúzska alebo talianska kuchyňa. Táto situácia sa začala pomaly menit’ v priebehu 60 . rokov 20 . storočia, ked'sa prestali objavovat články o hladujúcich pracujúcich v kapitalistických štátoch a naopak, kritizovali sa javy konzumnej západnej spoločnosti, predovšetkým rast spotreby tukov a cukrov v strave. V priebehu tohto desatročia sa začali na knižnom trhu postupne objavovał’ nové kuchárske knihy propagujúce kuchyne západných štátov. Najmä talianska a francúzska kuchyňa si získavali svojich obdivovatelov. Za prínos talianskej kuchyne sa považovali rôzne cestoviny, najmä špagety, ktoré sa dali rýchlo pripravit', d’alej pokrmy typu rizota a vína. Čo sa týka francúzskej kuchyne, oceňovala sa jej sofistikovanost' pri príprave jedál, syry, víno a koňak. Zmena vzt’ahu k západným gastronomickým tradíciám súvisela aj s obnovovaním cestovného ruchu a malo to pomôct’ najmä kuchárom, ktorí varili $\mathrm{v}$ interhoteloch a reštauráciách určených pre cudzincov. Do určitej miery išlo o návrat $\mathrm{k}$ haute cuisine, známej v 1. ČSR, avšak v modifikovanej socialistickej podobe. $\mathrm{V}$ reštauráciách a jedálňach sa ponúkali rôzne jedlá, ktoré mali svojimi názvami evokovat medzinárodnú kuchyňu, no často s ňou nemali nič spoločné. Príkladom boli jedlá ako: frankfurtská roštenka, belehradský rezeň, kyjevský rezeň, španielsky vtáčik, chateaubriand, stroganoff, filé Orly a pod. (www. ceskatelevize/porady/retro; Franc: 2003, 202 - 208).

V predslove knihy Medzinárodná kuchárka autori napísali: „Ciel’om knihy je vyplnit' medzeru a podstatne rozšírit’ sortiment u nás pripravovaných jedál o d’alšie, predovšetkým o tie, ktoré sa osvedčili v iných oblastiach sveta, a tak spestrit’ náš národný jedálny lístok. Z kuchýň národov sveta sme vybrali iba niektoré jedlá, ktoré sú prijatel'né pre našu kuchyňu, v našich klimatických podmienkach vhodné a vyhovujú zásadám správnej výživy. Najväčšie t’ažkosti pri výbere bývajú s nedostupnostou niektorých špeciálnych surovín, ale niekedy aj neprijatel'nost' jedla zo zdravotného hl’adiska. Aj preto bolo treba niektoré typické jedlá najmä pre ázijské a ju- 
hoamerické oblasti vynechat'. (...) Národné kuchyne v pravom zmysle slova už prestávajú existovat'. $V$ dôsledku zahraničného obchodu, potravinárskeho priemyslu v jednotlivých štátoch, zoýšenia cestovného ruchu a vplyvom výmeny informácií vo svetovom meradle prenikajú v ostatných rokoch do jednotlivých národných kuchýň aj proky internacionálne. (...) Život človeka v celom hospodársky vyspelom svete čoraz viac určujú rovnaké alebo podobné vplyvy (zamestnanost’žien, intenzifikácia práce, prevaha duševnej práce, bohatší kultúry život, cestovanie a pod.) a do značnej miery utvárajú aj svetový štandard výživy... (Fialová a kol.: 1967, 5).

Medzinárodnú kuchyňu reprezentovala v centre hlavného mesta Slovenska Mad’arská reštaurácia, taliansku kuchyňu reštaurácia Perugia, reštaurácia s čínskym personálom bola v okolí železničnej stanice, neskôr bola otvorená Čínska reštaurácia na Búdkovej ceste, ruskú kuchyňu ponúkalo bistro Kazačok. O medzinárodnú gastronómiu sa snažili aj v interhoteloch, ako boli Devín, Carlton a Kyjev. Zahraniční hostia ubytovaní v najdrahších hoteloch v Bratislave alebo v Pieštanoch sa však stažovali na nedostatok čerstvých zeleninových šalátov a ovocia na stoloch, čo pokladali za nepochopitelné.

Na Slovensku prebiehal proces internacionalizácie kulinárie súčasne s akousi prestavbou národnej či presnejšie povedané l'udovej kuchyne. Známy autor kuchárskych kníh Imrich Sečanský to zdôvodňoval takto: „...Je historickou skutočnostou, že väčšina typických slovenských jedál pochádza z obdobia nedostatku a biedy. Dnes ich pripravujeme ako tradičné jedlá, kriesime ich a slovenská kuchyňa slávi svoje zmŕtoychostanie. Naši kuchárski odborníci a majstri kuchári zvel’adili viaceré pôvodné jedlá, obohatili ich, technologicky upravili a povzniesli do vyššej, rafinovanej polohy. Tak vznikli mnohé nové jedlá - Jánošíkov ražen̆, zemplínska zbojnícka pečienka, topol’čiansky zámocký tel’ací paprikáš, cíferský bravčový rezeň, zbojnícka pochút'ka, thurzovská misa, sedliacka pochút'ka, šarišská sedliacka pochút'ka, ražeň Zochova chata, sviečkové rezy intehotel Devín, karpatská tel’acia pečeň, goralský guláš a iné..." (Sečanský: 1978, 163).

Táto tendencia $\mathrm{v}$ slovenskej gastronómii išla ruka $\mathrm{v}$ ruke s postupným rozvojom cestovného ruchu, ktorý propagoval prírodné 
krásy Slovenska. V rámci neho sa akcentovala aj potreba propagovania národnej kuchyne ako jeho dôležitého prvku. V hoteloch začali vznikat' „slovenské“" a „zbojnícke“ izby, zariadené štýlovým interiérom, ktoré mali navodit rustikálnu atmosféru Slovenska, a ponúkali sa tzv. slovenské špeciality. Pri hlavnej ceste Žilina - Vysoké Tatry bol v roku 1957 vybudovaný Salaš v Dechtároch. Stal sa prvou lastovičkou, ktorý svojím charakterom ludovej stavby a ponukou na jedálnom lístku mal vyjadrovat’ osobitosti slovenskej kuchyne. Po jeho úspechu medzi zahraničnými a domácimi návštevníkmi sa začala v 60. rokoch 20. storočia tzv. salašmánia - výstavba rôznych pohostinských zariadení nazvaných po pôvodných stavbách pastierov oviec ako „salaš“ alebo „koliba“, prípadne na zvýraznenie atraktívnosti „zbojnícka koliba“. Štylizovaná Slovenská koliba so slovenskými kulinárnymi špecialitami bola postavená aj v rámci československej expozície Expo 1967 v kanadskom Montreale. Po ukončení výstavy stavbu previezli na bratislavskú Kolibu, kde dlho patrila k vyhladávaným reštauráciám. Paradoxom doby bolo, že výstavba salašov sa často diala bez akejkolvvek koncepcie, nezriedka aj v regiónoch, kde sa nikdy ovčiarstvo nerealizovalo. Niektoré stavby sa snažili zachovat’ akýsi kolorit tradičných pastierskych stavieb boli zrubové so šindlovou strechou, no mnohé z nich okrem názvu nemali s takýmito stavbami nič spoločné. To isté sa dá povedat’ aj o interiéroch týchto pohostinských zariadení (Petkeš: 1967, 89 - 90). Ani ich ponuka väčšinou nespĺňala požadovanú úroveň, kladenú na takéto špecializované stravovacie zariadenia. Základným sortimentom boli polievky - kapustnica alebo fazul'ovica, premastené bryndzové halušky, prípadne strapačky s kyslou kapustou, zabíjačkové špeciality (klobása, jaternica, tlačenka) alebo cigánska pečienka (bravčové mäso prudko opečené na tuku). Ovčí syr alebo iné ovčie výrobky boli zriedkavostou, podobne ako iné regionálne špeciality. Určite ste na salaši dostali kávu, čaj a alkoholické nápoje, ale vel'mi zriedka žinčicu.

Celý proces snahy o zatraktívnenie slovenskej originálnej kuchyne mal totiž tragikomický kontext. Dial sa približne v rovnakom 
čase, ked’ sa v rámci kolektivizácie pol’nohospodárstva rapídne znižovali chovy oviec, likvidovali sa tradičné koliby a salaše v horách, a tým aj zdroje, z ktorých mohli čerpat' tzv. slovenské špeciality. A bryndza, ktorá sa vyrábala už len továrensky, mala k tej originálnej z bryndziarní vel’mi d’aleko (Stoličná: 2002, 24 - 25).

Takisto v Bratislave v pasáži Luxor bola otvorená Slovenská reštaurácia, zariadená v rustikálnom štýle, kde obsluhovali čašníci v štylizovaných ludových odevoch. Tu okrem už spomínaných „typických" slovenských špecialít ponúkali aj l’udové jedlá ako bryndzové halušky, kapustové strapačky, šúlance s makom, kyslé mlieko. Bola to vel'mi oblúbená reštaurácia, kde sa chodili najest' herci, spisovatelia, výtvarníci, vedci, novinári, pozývali do nej aj zahraničných hostí. Návštevník Slovenska však nemal šancu ochutnat’ skutočne originálne krajové alebo lokálne špeciality slovenskej kuchyne. Bránili v tom najmä predpisované normy, ktoré museli všetky stravovacie zariadenia dodržiavat', takže snaha o akúkol'vek kreativitu kuchárov bola zbytočná.

Všetky reštaurácie boli riadené centrálne podnikom Reštaurácie a jedálne (RaJ). Ten sa staral o vybavenie týchto zariadení nábytkom a riadom, stanovoval aj normy, podl'a ktorých museli všetci kuchári varit', a zároveň rozhodoval o tom, do akej cenovej kategórie bol podnik zaradený. Najbežnejšie reštaurácie a bufety patrili do tretej cenovej kategórie, kde sa dalo najest' lacno. A ako hodnotili naše reštaurácie a stravovanie významné osobnosti na konci 70. rokov 20. storočia? Na ich názor sa pýtal týždenník Život: "Strava v našich reštauráciách bežného typu je mizerná. Jedlá u nás sú poväčšine bez chuti. Kúsok mäsa, obliate neutrálnou št́avou. To, že niekde uvaria dobrý prívarok, je priam zázrak." (B. P.) - "Kultúra stravovania u nás je ešte stále nízka. Je to tak preto, že väčšina l’udí má rada t'ažké a jednotvárne jedlá. Negatívnou stránkou nášho stravovania je predovšetkým nedostatok čerstvej zeleniny na stole." (M. K.) - "O úrovni nášho stravovania sa už vel’a popisalo, ale nemôžeme povedat,' že by sme sa boli poučili z týchto učených úvah. Mnoho knedlí a múčnych jedál v rôznych formách... Ďalšou chybou je, že sme si nevytvorili podmienky pre kultúrne konzumovanie jedla a že 
nemáme čas... Niektoré proky v kultúre stravovania - to je niekedy vec neznáma. Kvetiny, farebné obrusy, pekný pohár namiesto ,horčičiaku' sú vzácnost’ou v každodennom stravovaní." (L'. B.) - „Kultúra stravovania u nás je vzhl'adom na výšku doby malá, nerovnomerná. Hrešime najmä proti kvalite jedla a hygiene skladovania a prípravy. Zodpovedné orgány nevedia, nestačia a možno ani nechcú udržat' a kontrolovat' predpisy v tomto smere." (R. F.) Ako konštatoval odborník na výživu I. Sečanský, "tieto odpovede v skratke vyjadrujú reálny stav namiesto dlhých traktátov" (Sečanský: 1978, 13 - 14).

Najest' sa dalo aj v lepších vinárňach, kam sa však chodilo predovšetkým na víno. V Bratislave, ktorá má stáročnú tradíciu vinárstva, sa aj v socializme zachovali tieto zariadenia. K najznámejším vinárňam patrili Malí a Vel'kí Františkáni, U Zbrojnoša, Kláštorná vináreň, Pod Baštou, Slovenská pivnica pri Liga pasáži. Existovali aj lacnejšie vinárne, napríklad Vysoká 44, Dekanát, Šenkvická viecha, Drevená dedina na trhu na Žilinskej ulici. Niektoré vinárne boli privátne, napríklad Jankobáči, Feribáči, Julka, ktoré sa akýmsi zázrakom zachovali v pivniciach starých vinohradníckych domov. "Do vinární sa chodili l'udia zabávat', zabudnút’ na starosti a t'ažkosti, uvol'nit' sa. Posediet’ vo vinárni, to bola skrátka radostná udalost'. Cigáni vyhrávali a l'udia spievali. Víno bolo lacné a piesne dlhé. Pili sa sudové vína, biele či červené, sladké či suché, mladé či kabinetné..." (Šebo: 2008, 49).

Pivo a iný alkohol muži radi konzumovali v bývalých krčmách, počas socializmu nazývaných POHOSTINSTVO alebo BUFET. Chodili tam najmä kvôli atmosfére, a to aj napriek tomu, že pivo tam často bolo nekvalitné, málo vychladené a zanedbávala sa hygiena predaja. Ako to fungovalo v týchto najlacnejších zariadeniach s predajom alkoholických nápojov, môžeme si urobit’ obraz z opisu L. R. na internete: „...Pod pultom nalejeme vodku do poldecáka. Mali by sme nalievat’ po rysku, ked’že však pod pult nikto nevidí a alkohol aj tak nalievame v tom čase nezákonne, môžeme si dovolit' nedoliat', po troche tak ušetríme značné množstvo alkoholu, ktorý neskôr predáme bez nablokovania a peniaze si strčíme do vrecka. Vodku z poldecáka prelejeme do dvojdecového pohára. Do jednej ruky vezmeme flašu s malinovkou, do druhej 
dvojdecový pohár s vodkou, a dolievame malinovkou. Začneme dolievat' pod pultom pričom postupne presúvame ruky na pult, kde dolievanie dokončíme. Náhodný pozorovatel' tak získa dojem, že ide len o malinovku. Pri kofole s rumom postupujeme obdobne. Nápoje zbytočne nechladime, zákazník aj tak nemá na výber, netreba sa bát', že ho stratíme, to my sme pri zdroji a on je v úlohe prosebníka, čo žiada nápoj... Tieto nápoje nazývame ,studený čaj'..."

Na pivo a lacné jedlo sa v Bratislave chodilo k Steinovi, do Smíchovského dvora, Meštianskeho pivovaru, Kriváňa, Hrona, Kysuckého hostinca, Budvaru, Riviéry, do Funusu, k Albrechtovi, Hasičovi, do Besedy, na Hlavnú stanicu a d’alších podnikov. Zhruba od 80. rokoch 20. storočia sa zvyklo chodit aj do najväčšej pivárne v meste, nazývanej Mamut. Atmosféru týchto socialistických podnikov pôsobivo opísal J. Šebo vo svojej knihe: „....Hovorilo sa, že kto sa chcel dozvediet' pravdu, mal ist' do krčmy alebo $k$ holičovi. Z pohl'adu modernej psychológie to bola osobitná forma duševnej a sociálnej psychohygiény. V tých krčmách bolo možné napáchnut’ človečinou, dalo sa tam skryt' pred úzkostlivým pohl'adom rodičov, frajeriek, vol'ne fantazírovat' a čo nie je nepodstatné, zapit’ to dobrým trúnkom. Každá krčma mala svojich štamgastov. V krčmách sa uzatvárali kamarátstva a bolo tam veselo. Pilo sa najmä čapované pivo, z tordého alkoholu borovička, rum, vodka, tí fajnovejší koňak a džin. Oblúbená bola kofola s rumom, pivo s borovičkou či vodka s džúsom..." (Šebo: 2008, 48 - 49).

Na kávu, prípadne zákusky sa chodilo najčastejšie do kaviarní, ktoré boli súčastou hotelov, alebo do špecializovaných kaviarní. V centre Bratislavy boli najznámejšie kaviarne Grand (v najvyššom dome v meste, v tzv. Manderláku), Luxor, Vel'ké srdce, Štefánka, Carlton-Savoy, Park, Olympia, Metropol, Krym, U Michala, Tatra. Na dobrú kávu sa chodilo do expressa Tulipán, do Malého Muka či Obchodného domu Dunaj.

Pani R. M. spomína na obdobie svojej mladosti takto: „...Ako študentka som najčastejšie chodila do Krymu. Do tejto kaviarne chodili najmä študenti a pedagógovia Filozofickej a Právnickej fakulty UK, novinári $z$ redakcie denníka Smena a pracovníci $S A V$ z Klemensovej ulice. Vd’aka 
kultovej postave čašníka Pepa sa tam dalo konzumovat' aj na dlh. Študenti, ktorí bývali na internátoch pri Horskom parku, chodili na pivo a kofolu do Funusu, kde sa dalo od jari do jesene sediet' vonku pod stromami. Ak som mala peniaze, chodila som sa najest' do bistra Krym. Ked' som začala pracovat'v $S A V$, dostávali sme lístky, za ktoré sme sa mohli stravovat'v niektorých reštauráciách, napríklad v Pol’ovníckej reštaurácii, ale najčastejšie sme išli na tresku s rožkom do Ryby na Leninovom námestí. Oblúbený sme s kolegami mali aj Kazačok na Šafárikovom námestí, kde sme chodili na boršč a tatársky biftek..."

Úplnou raritou socialistického spôsobu stravovania boli cesty obyvatelov Československa do zahraničia, predovšetkým do Juhoslávie. Táto krajina patrila síce do tzv. socialistického tábora, avšak s nádychom kapitalizmu a bolo pomerne l’ahké dostat' sa $\mathrm{z}$ nej do Rakúska alebo Talianska. Vycestovat’ do Juhoslávie k moru bolo snom mnohých ludí, ktorí však museli prejst' pred tým administratívnou tortúrou. Ak sa nešlo organizovane s cestovnou kanceláriou, muselo sa počiatkom roka požiadat Československú štátnu banku o devízový prísl'ub s odporúčajúcim listom od zamestnávatel’a. Banka sa potom rozhodla, či občanom žiadané devízy, pre Juhosláviu to boli dináre, predá. Tým sa to však nekončilo. Devízový príslub a žiadanka o vycestovanie sa musela podat' na ministerstvo vnútra, aby l'udia dostali tzv. výjazdovú doložku, a až na jej základe mohli vycestovat'. Devízový príslub býval vel'mi nízky a československé koruny sa v Juhoslávii nedali zamenit'. Preto l’udia, ktorí mali št’astie a mohli do Juhoslávie vycestovat individuálne autom, vozili so sebou do kempingov vlastne všetku stravu a varili si na propán-butánových prenosných varičoch. A ked’že sa jazdilo na tri týždne, museli to mat' premyslené tak, aby potraviny vydržali čo najdlhšie. Pani M. R. spomína: „.... Išli sme do Juhoslávie. Auto naložené po strechu. Zaváraná paradajková omáčka a guláš, zemiaky, cibul'a, cestoviny, polievky vo vrecúškach, v chladiacich taškách chlieb a maslo. Pridelené dináre stačili tak na benzín a ubytovanie, trocha základných potravín a pár kopčekov zmrzliny. Urobit’ poriadny nákup znamenalo íst’ o týždeň domov... Ten, kto prepašoval západonemecké marky alebo iné valuty, si mohol dovolit' 
sadnút’ aj na večeru a ochutnat’ miestne špeciality. To boli nezabudnutelné zážitky!“( Pravda - víkend, 1. 6. 2013, 6). „...Pri cestách do Juhoslávie sa aj pašovalo. V hoteloch sa predávali uteráky, domáci na privátoch privítali, ak ste im priniesli niekol'ko kíl eidamu či iného tordého syra, ktorý bol u nás vtedy podstatne lacnejší. Spustili vám z ceny za ubytovanie, upiekli na večeru ryby, položili na stôl flašku domáceho červeného vína či ostrú rakiju" (Šebo: 2009, 161).

V čase socializmu nastali zásadné zmeny $\mathrm{v}$ oblasti verejného stravovania. Odborníkom na výživu aj ideológom išlo najmä o naplnenie hlavného ciel'a: prejst' od rodinného spôsobu stravovania ku kolektívnemu a odbremenit tak socialistickú ženu od prác v kuchyni. Preto sa sústred’ovali najmä na vybudovanie vývarovní pre deti i pracujúcich, kde sa mala strava pripravovat podla predpísaných zdravotných a nutričných noriem a zabezpečit tak zdravý vývin l'udí. Zapojením masy l'udí do tohto typu verejného stravovania došlo $\mathrm{k}$ radikálnym zmenám $\mathrm{v}$ stravovaní vo vidieckych i mestských rodinách, kde sa postupne cez pracovné dni prestal varit' obed a l'udia doma zvykli iba raňajkovat’ a večerat', aj to často $v$ rôznych časoch. Preto sa nedelný obed postupne stal najdôležitejším spoločným jedlom a rodinným stretnutím.

Pri komerčnom verejnom stravovaní nastali tiež podstatné zmeny. Vzhl'adom na nedostatok dostupných tzv. luxusných a niekedy aj bežných potravín socialistické reštaurácie museli rezignovat’ z náročnej haute cuisine, ktorá bola v predvojnovom období v drahších reštauráciách bežná. Tento nedostatok sa snažili socialistické reštaurácie vykryt’ niektorými jedlami z kuchýň spriatelených socialistických štátov a snahou o vytvorenie tzv. slovenskej národnej kuchyne so špecialitami, ktoré však s pôvodnými lokálnymi a regionálnymi jedlami tradičnej kuchyne mali vel’mi málo spoločného. Najmä v reštauráciách a stravovacích zariadeniach nižšieho cenového zaradenia bola diskutabilná kvalita a hygiena predávaných jedál a nápojov. Napriek snahe prebudovat’ staré krčmy na prevádzky hodné socializmu sa to väčšinou nepodarilo. Typickým fenoménom 
obdobia socializmu sa stali - a nielen na Slovensku - mliečne bary, kde sa ludia radi chodili najest'. Oblúbené boli aj návštevy kaviarní a cukrární, ktoré už nenavštevovali ako kedysi len meštania, ale aj vidiečania, ktorí v meste pracovali alebo mali cestu do mesta.






\section{VÝSLEDKY ANKETY \\ O SPÔSOBE STRAVOVANIA \\ V ČASE SOCIALIZMU}

Analýza dobových prameňov o možnostiach a praktikách stravovania l'udí v období socializmu ukázala jeho pozitívne i negatívne stránky. Bolo preto zaujímavé opýtat' sa, ako si l'udia na tieto skutočnosti spomínajú po štvrt’storočí. Použila sa anketa určená l'ud’om narodeným pred rokom 1970, teda l'ud’om, ktorí zažili obdobie socializmu ako dospelí. Anketu v rokoch 2013 - 2014 vyplnilo osemdesiat náhodných respondentov z bratislavského, trnavského, žilinského a košického regiónu, polovica z mestského a polovica $z$ vidieckeho prostredia. Anketa bola tematicky rozdelená na tri časti: I. Potraviny; II. Každodenné stravovanie; III. Príležitostné stravovanie. Respondenti mali opísat’ stav v čase končiaceho sa obdobia socialistického režimu.

$\mathrm{V}$ časti o potravinách sa otázky ankety sústredili na zdroje ich získavania a kvalitu. Až 91 \% mestských obyvatel'ov uviedlo, že základné potraviny nakupovali v samoobslužných predajniach a d’alšie potraviny najviac v mäsiarstve, obchode so zeleninou a ovocím a pekárni, kde sa uplatňoval ešte pultový predaj. Jedenást’ percent z týchto respondentov uviedlo, že využívali donášku potravín (mlieka a pečiva) domov. Vidiecke obyvatel'stvo nakupovalo potraviny v samoobsluhe v 53 \% a v 47 \% v obchodoch s pultovým predajom. Ďalšie potraviny nakupovali predovšetkým v mäsiarstve, mliekarni a zelovoci. Donáška potravín do domu v tomto prípade nebola zaznamenaná.

$\mathrm{Na}$ otázku, aké bolo zásobovanie potravinami v obchodoch, respondenti z mesta odpovedali nasledujúco: za vel'mi dobré ho 
neoznačil nikto, $31 \%$ ho označilo za dobré, 36 za dostatočné a $33 \%$ za nedostatočné. Na rovnakú otázku respondenti z vidieka zásobovanie hodnotili nasledovne: nikto ho nepovažoval za vel'mi dobré, 34 \% za dobré, $33 \%$ ho označilo za dostačujúce a $33 \%$ za nedostatočné. Ako nedostatkové potraviny mestskí l’udia uviedli: ovocie, južné ovocie, zeleninu, ryby, mäso, jogurty, olej, pečivo; vidiečanom chýbali ovocie, južné ovocie, mäso, mliečne výrobky, ryby, čokoláda. Jedna z respondentiek k tejto téme pripísala: „Bolo dostat' to, čo bolo potrebné $k$ životu, širku výberu potravín na Západe sme nepoznali. Výber v rámci druhov potravín bol síce úzky, ale v zásade bolo dostat' bežné potraviny. Vo večerných hodinách už nebol napr. chlieb, pečivo, mlieko, podobne to bolo aj pred sviatkami." Na otázku, ktoré druhy potravín chýbali v obchodoch dlhšie obdobia, respondenti uviedli: maslo, olej, šlahačka, vajíčka, zemiaky, banány, mandarínky, pomaranče, figy, kokosová múčka, hrozienka, lieskovce, vlašské orechy.

Na otázku: Ktorým „socialistickým“ potravinám by ste dali najvyššie ocenenie kvality? - respondenti z mesta napísali: chlieb, mlieko, jogurty, mäso; respondenti z vidieka uviedli: chlieb, pečivo, mlieko, maslo, jogurty, mäso, mäsové výrobky, vajíčka.

Anketa sa pýtala aj na opačný názor, teda ktorým „socialistickým" potravinám by respondenti dali najnižšie ocenenie kvality. Mestskí respondenti uviedli: pečivo, mäso, salámy, párky, zelenina, ovocie, kubánske pomaranče, pochutiny, malinovky; respondenti z vidieka odpovedali: mäso, mäsové výrobky, ovocie, zelenina. Treba dodat', že na túto otázku viac ako polovica l'udí neodpovedala a viacerí napísali, že boli s kvalitou potravín spokojní a že bola lepšia, ako je v súčasnosti.

$\mathrm{V}$ rámci bloku o potravinách bola položená aj otázka, ktoré „,socialistické" potraviny by l'udia radi videli na súčasnom trhu. L'udia z mesta odpovedali takto: chlieb, jogurty, maslo, smotana, mliečne výrobky, mäso, údeniny, mäsové konzervy, ovocné mušty, naše ovocné kompóty, zákusky, niektoré druhy cukríkov. Vidieckym obyvatel'om dnes chýbajú tieto „socialistické“ potraviny: mlieko vo 
vrecku alebo vo flaši, jogurty, pivo, vinea. Na túto otázku viacero respondentov odpovedalo $\mathrm{v}$ tom zmysle, že by privítali všetky „socialistické“ potraviny, pretože boli kvalitnejšie ako dnes, bez zbytočných konzervantov a lepšie chutili. Na druhej strane niektorí l'udia odpovedali, že dnes je vel'ký výber potravín a žiadne im nechýbajú.

Ďalšia otázka sa pýtala na spokojnost’ l’udí s kvalitou predaja potravín. L’ud’om z mesta v období socializmu najviac prekážal spôsob predaja chleba, pečiva, mlieka vo vreckách, mäsa, zeleniny, ovocia a respondentom $\mathrm{z}$ vidieka prekážal predaj mlieka vo vreckách, pečiva, mäsa, výrobkov z mäsa, šalátov, mrazených potravín. Jedna $\mathrm{z}$ respondentiek k tomu napísala: „Chlieb sa dovážal v prepravkách, ktoré sa t’ahali po zemi a potom sa rukami vyṫahoval na regály, predavačky ho krájali bez rukavíc a kupujúci si ho kládli bez zabalenia spolu s inými potravinami do košíka. Podobne to bolo aj s pečivom. Najhoršie to bolo s mliekom vo vreckách, ktoré sa transportom prederavili a vytekali do prepraviek, z ktorých si l'udia mlieko museli vyberat'. Bolo to vel'mi nehygienické.“ Ďalšia žena z anketovaných zasa poznamenala: „Najviac ma rozčulovalo balenie mäsa a šalátov do hrubého papiera, ktorý sa rozmočil a na potravinu sa prilepil." Viacerí z anketovaných l'udí napísali, že by všetky nedostatky socialistického trhu odpustili, ak by nemuseli na niektoré potraviny stát' v dlhých radoch.

Ďalšia skupina otázok ankety sa pýtala na alternatívne zdroje potravín, teda či mali l'udia možnost’ zaobstarat' si potraviny inak ako v obchode. Až 86 \% respondentov, ktorí bývali v meste, uviedlo, že mali takú možnost', pričom 63 \% malo potraviny z vlastnej záhrady, $25 \%$ z domáceho chovu zvierat a 54 \% mohlo získat potraviny od príbuzných alebo známych. Samozásobitel'stvo potravinami v dedinskom prostredí bolo ešte vyššie. Až 100 \% l'udí uviedlo, že mali dostup k iným zdrojom potravín, z čoho 100 \% z vlastnej záhrady alebo záhumienka a 80 \% z vlastného chovu zvierat. Respondenti tiež uviedli, že si dorábali aj domáce alkoholické nápoje. Na otázku, či si doma robili víno, odpovedalo kladne 42 \% l'udí z mesta a $22 \%$ uviedlo, že mali možnost’ dorobit’ si domácu pálenku. V dedinskom 
prostredí si domáce víno dorábalo $53 \%$ a domácu pálenku $26 \%$ opýtaných l’udí.

Ďalším zdrojom potravín bol nákup na trhoch. To podla výsledkov ankety využívalo 75 \% mestského obyvatel'stva a 46 \% vidieckeho obyvatel'stva. Okrem ovocia a zeleniny l'udia na trhoch nakupovali slaninu, jaternice, klobásy, sliepky, kačky, husi, ovčie syry, vajíčka, kyslú kapustu, med, huby, sušené korenie.

Anketa sa pýtala respondentov aj na možnost' nákupu potravín v Tuzexe, v podniku zahraničného obchodu, kde bolo treba platił tzv. bonmi, ktoré sa vymieňali za valuty alebo sa kupovali načierno. Na otázku odpovedalo kladne 52 \% l’udí z mesta a 66 \% l’udí z vidieka. Z potravín, ktoré nakupovali v Tuzexe, to boli: alkoholické nápoje, syry, čokolády, sladkosti, kakao, káva, žuvačky.

Druhá čast̉ ankety sa zamerala na každodenné stravovanie. Najskôr sa otázky pýtali na vybavenost’ domácností v čase končiaceho sa socializmu. Z odpovedí vyplynulo, že 100 \% mestských respondentov malo v domácnosti zavedený vodovod, $100 \%$ malo chladničku a 80 \% vlastnilo aj mrazničku, a to bud' v rámci chladničky, alebo osobitne. $\mathrm{V}$ dedinskom prostredí malo doma zavedený vodovod 93 \% l'udí, zvyšok čerpal vodu zo studne, 100 \% l’udí malo chladničku a $46 \%$ aj mrazničku. Stravu na plyne si pripravovalo $88 \%$ mestských domácností, na elektrine $16 \%$ a na dreve alebo uhlí $5 \%$, pričom obe tieto možnosti niekedy $\mathrm{v}$ kombinácii s plynom. V dedinskom prostredí uviedli respondenti, že v domácnosti varili v 80 \% ešte na dreve alebo uhlí a 33 \% z nich uviedlo aj varenie na plyne alebo elektrine. Strava sa všeobecne pripravovala v kuchyni, v dedinskom prostredí pri 13 \% opýtaných aj v letnej kuchyni.

$\mathrm{Na}$ otázku, kde $\mathrm{v}$ pracovný deň obedovali, odpovedali l'udia z mesta takto: mimo domu v $88 \%$ a doma v $12 \%$. L'udia sa väčšinou naobedovali $\mathrm{v}$ jedálni na pracovisku alebo $\mathrm{v}$ školskej jedálni, $5 \%$ z nich uviedlo, že sa niekedy išli najest’ aj do bufetu. Výsledky ankety v dedinskom prostredí boli nasledujúce: 80 \% l'udí obedovalo v pracovný deň mimo domu na pracovisku alebo v škole a 33 \% zjedlo obed väčšinou doma. Na otázku, ako boli spokojní 
s kvalitou jedál v spoločných jedálňach, väčšina l'udí ju označila za dobrú. K jedlám, ktoré l'ud’om v socialistických vývarovniach nechutili, patrili polievky, konkrétne paradajková, omáčky, prívarky, osobitne špenát, mrkvový prívarok a hrachová kaša, vnútornosti, najmä plúcka na smotane, mleté mäso, sladké jedlá, napríklad ryžový nákyp, rezance s makom. Viac l’udí konštatovalo, že jedlá by neboli bývali zlé, ak sa boli podávali dostatočne teplé. $Z$ ankety d’alej vyplýva, že najdôležitejším jedlom mestskej i vidieckej rodiny počas týždňa bol spoločný domáci nedelný obed.

Tretia čast’ ankety sledovala problematiku príležitostného stravovania l'udí v čase končiaceho sa socializmu. Čast’ otázok bola zameraná na príležitostné stravovanie mimo domácnosti. Na otázku, či l'udia chodili občas na nedel'ný obed do reštaurácie, odpovedalo kladne $16 \%$ respondentov z mesta a nikto z vidieka. Príležitostné návštevy v kaviarni deklarovalo $69 \%$ meštanov a $13 \%$ vidiečanov a v cukrárni $72 \%$ opýtaných z mesta a $73 \%$ z vidieka. Anketa sa pýtala aj na to, či si l'udia robili tzv. opekačky v prírode. Na túto otázku odpovedalo kladne $66 \%$ obyvatel’ov mesta a $80 \%$ obyvatelov z dedín.

Ďalšia čast’ otázok sa zameriavala na mieru zachovávania tradičného stravovania počas kalendárnych a rodinných sviatkov. Z odpovedí vyplýva, že niektoré tradičné jedlá (napr. rybacia polievka, kapustnica, strukovinová polievka alebo kaša, opekance, ryba, zemiakový šalát, oblátky, med, koláče, ovocie) malo na stole počas Štedrej večere $91 \%$ meštanov a $100 \%$ dedinčanov, pričom v mestských domácnostiach tvorili vianočné menu zväčša polievka, ryba so zemiakovým šalátom, oblátky, ovocie, koláče. Na dedinách bolo toto menu širšie: podávali sa napríklad dve rôzne polievky, kaša, opekance. Z d’alších termínov l'udového kalendára sa kulinárne tradície zachovávali aj počas fašiangov a sviatkov Velkkej noci: $63 \%$ opýtaných l'udí z mesta a 86 \% l'udí z vidieka deklarovalo, že na fašiangy pripravovali $v$ domácnostiach tradičné vysmážané pečivo šišky alebo fánky. Niektoré z tradičných vel'konočných jedál (vajíčka, šunka, klobása, syr, koláče) malo na stole 69 \% l'udí z mesta 
a $92 \%$ vidiečanov, pričom 25 \% opýtaných l’udí z mesta a 33 \% ludí z vidieka odpovedalo, že aj v čase socializmu si dávali vel'konočné jedlá posvätit kňazom v kostole.

$Z$ rodinných sviatkov sa anketa zamerala na svadobné hostiny, kary a iné príležitostné pohostenia. Na otázku, či sa na príprave svadobnej hostiny podiel'ali príbuzní svadobného páru darmi v podobe potravín alebo jedál, ako to bolo zvykom v tradičnom svadobnom obrade, odpovedalo kladne 52 \% l’udí z mesta a 100 \% l'udí z vidieka. Anketa d’alej ukazuje, že v čase končiaceho sa socializmu sa svadobné hostiny robili väčšinou už mimo svadobných domov, v mestách hlavne v reštauráciách a hoteloch, čo deklarovalo $93 \%$ opýtaných, a na dedinách taktiež predovšetkým v reštauráciách, hoteloch či kultúrnych domoch, čo deklarovalo 73 \% opýtaných. Podobné výsledky platia aj pri usporiadaní karov po pohrebe. Aj tu mestskí respondenti potvrdili, že kary sa robili v 89 \% mimo domu, najmä v reštauráciách, kým dedinskí respondenti to potvrdili v 73 \%. Zvyšok opýtaných uviedol, že kary sa robili v dome zosnulého.

Anketa sa zamerala aj na d’alšie príležitosti, pri ktorých sa v rodinách robilo slávnostné pohostenie. Z odpovedí vyplynulo, že sa takto oslavovali najmä narodeniny, meniny, maturita, promócia, jubilejné výročia sobáša, prvé sväté prijímanie alebo birmovka. Na otázku, kde sa takého pohostenie konalo, l'udia z mesta uviedli, že promócia člena rodiny, okrúhle 50., 60., 70. či 80. narodeniny a zlatá či diamantová svadba sa oslavovali zväčša mimo domu, najmä $\mathrm{v}$ reštauráciách, a ostatné príležitosti v domácom prostredí. Na dedinách sa takéto oslavy konali väčšinou doma.

Získané odpovede ankety, v ktorej respondenti spätne hodnotili možnosti a príležitosti stravovania v čase končiacej sa éry socializmu na Slovensku, potvrdili mnohé fakty, ktoré zaznamenali už dobové dietologické, etnografické i socio-ekonomické výskumy.

Viaceré skutočnosti z konca 80 . rokov 20. storočia potvrdzujú vysokú fázu modernizácie slovenskej spoločnosti v oblasti stravo- 
vania. Predaj potravín v mestách i vo väčších dedinách bol zabezpečovaný samoobslužnými predajňami, kde sa dali nakúpit’ všetky základné potraviny s výnimkou ovocia, zeleniny a mäsa, ktoré sa stále predávali v špecializovaných pultových predajniach. Zásobovanie potravinami hodnotila väčšina opýtaných l'udí ako dobrú alebo uspokojivú, pravda, s upozornením, že niektoré druhy potravín neboli v predajniach konzumentom vždy k dispozícii. Kvalitu potravín predávaných za socializmu hodnotili l’udia zväčša pozitívne.

Vybavenost' domácností vodovodom, chladničkou, mrazničkou či zariadením na prípravu jedál na plyn alebo elektrinu signalizuje taktiež vysokú mieru modernizácie, a to tak v mestách, ako na dedinách.

Podobne to môžeme konštatovat' o každodennom stravovaní počas pracovných dní, ked' väčšina ludí obedovala vo verejných jedálňach v školách alebo na pracovisku. Dá sa povedat', že jeden z deklarovaných ciel'ov socialistických odborníkov na výživu, zabezpečit všetkým sociálnym skupinám l'udí možnost̉ kvalitne a kaloricky vyvážane sa najest', sa v podstate splnil. Táto forma kolektívneho stravovania sa síce nevyhla istej kritike konzumentov, je však nesporné, že do tradičného slovenského stravovacieho stereotypu, ktorý bol typický pre slovenské vidiecke a malomestské prostredie ešte v prvej polovici 20. storočia, priniesla nové druhy jedál predovšetkým z českej, ale aj medzinárodnej kuchyne.

Počas socializmu sa každodenný spôsob stravovania členov rodín pod vplyvom rôznorodej práce dospelých a štúdií detí silne individualizoval, preto sa najdôležitejším spoločným jedlom rodiny počas týždňa stal domáci nedel’ný obed.

Anketa však zároveň potvrdila aj prežívanie istého druhu konzervativizmu v oblasti stravovania. Možno to dokumentovat’ vysokou mierou samozásobitel'stva socialistického typu mestských i dedinských rodín, ktoré si týmto spôsobom dopĺn̆ali zdroje potravín. Pramenilo to z nedostatočnej viery l'udí, že im socialistický trh a zásobovanie zabezpečí potraviny kvalitné a v dostatočnom množstve.

Aj odpovede respondentov $\mathrm{k}$ problematike konzumácie jedál 
počas kalendárnych i rodinných sviatkov potvrdili, že na socialistickom Slovensku prežili mnohé tradičné stravovacie zvyklosti, známe z predindustriálneho obdobia spoločnosti, a socialistická modernizácia ich výrazne nezmenila. Možno to ilustrovat' najmä na skladbe Štedrej večere a vel'konočného menu, v ktorých sa zachovali mnohé tradičné jedlá s pôvodnou prosperitnou alebo náboženskou symbolikou.

Respondenti ankety poslednú fázu socializmu hodnotili s odstupom štvrtstoročia z hladiska kvality stravy a možností stravovania prevažne kladne. Treba však pripomenút', že tieto údaje môžu byt’ poznamenané tzv. spomienkovým optimizmom, ktorý môže čiastočne deformovat' skutočný stav skúmanej problematiky, a treba ho konfrontovat’ s faktami, ktoré priniesli dobové výskumy a pramene. 


\section{ZÁVER}

Obdobie po druhej svetovej vojne znamenalo pre Slovensko viditel'né a výrazné modernizačné zmeny a rast životnej úrovne obyvatel'stva. Preto v spomienkach ludí často rezonujú aj pozitívne zmeny, ktoré priniesol politický režim socialistického štátu. V prvom rade išlo o industrializáciu. Výstavba priemyselných závodov, ktorá z vel'kej časti mužskej populácie urobila robotníkov, bola do konca 60. rokov 20. storočia chápaná ako dar z nebies, umožňujúci najmä súkromným rolníkom prežit i v dobách ekonomických postihov, ked' museli zo svojich majetkov platit vysoké dane a odvádzał velkú čast úrody. Táto zásadná sociálna zmena slovenskej spoločnosti je interpretovaná pamätníkmi všeobecne ako kladná črta doby. Iný charakter majú spomienky na združstevňovanie polnohospodárstva, ktoré bolo vnímané ako násilný zásah štátu do overeného tradičného dedinského života. Mnohí ludia pocitovali zakladanie jednotných rolníckych družstiev a štátnych majetkov ako vel'kú nespravodlivost’ voči dedinčanom. V 70. rokoch 20. storočia však vidiečania túto zmenu už oceňovali v zásade kladne a väčšinou s ňou spájali modernizačné a kultúrne zmeny, ktoré zo združstevnenia pre ich život vyplývali (Kandert: 2004, 233 - 235).

Socialistická modernizácia, ktorej súčastou bola aj kolektivizácia, neznamenala len úsilie o modernizáciu rolníckej komunity. Podla kolektivistických predstáv išlo aj o spochybnenie dovtedy platného sveta hodnôt, zmysluplnosti vlastníctva, predovšetkým vlastníctva pôdy, čo znamenalo zrútenie základného piliera materiálnej hodnoty, ktorým bola pre rolníka pôda. Spolu s tým sa zmietol i jestvujúci princíp sociálneho rozvrstvenia. Socialistická modernizácia podmienila del'bu medzi pracovným a domácim životom, medzi platenou a neplatenou prácou. Zasiahla do rodinného života, ktorého chod sa 
zmenil a platená práca (najmä žien) v družstve sa kombinovala s platenou prácou (najmä mužov) v priemysle. Narastal počet vidieckych domácností vyludnených počas pracovných dní, menila sa del'ba práce v rodine, postavenie žien a detí (Danglová: 2006, 25 - 26).

Socialistická modernizácia zákonite zasiahla aj do stravovacích modelov ludí na Slovensku, predovšetkým v rurálnom prostredí. Rolnícke domácnosti postupne prestali byt’ sebestačné v zásobovaní potravinami a boli odkázané na ponuku štátnych obchodov. Prípravu stravy preto ženy museli prispôsobit novým podmienkam a preorganizovat’ práce $\mathrm{v}$ domácnosti. $\mathrm{V}$ tradičných dedinských i mestských rodinách bola žena-matka tou osobou, ktorá pripravovala stravu pre členov rodiny. Zaradením sa do pracovného procesu v období socializmu jej táto úloha zostala, no popri inom zamestnaní. Stravovanie v rodinách sa preto muselo prispôsobit novým zamestnaniam jej členov a silne sa individualizovalo.

Napriek iste úprimnej snahe najmä vedcov o dostupnost', vyváženost', pestrost’ a zdravotnú kvalitu potravín, nebola výživa obyvatel'stva počas budovania socializmu bez problémov. Najmä v prvých dvoch desatročiach tejto éry bolo zadováženie aj tých základných potravín často spojené s nepríjemnými zážitkami ludí, vyplývajúcimi z ich nedostatku, zlej kvality, straty času pri ich zháňaní a v niektorých prípadoch i z vysokých cien. Drahé a často aj nedostupné potraviny mali, samozrejme, negatívny vplyv aj na výživové modely obyvatel'stva, ked' boli rodiny často nútené pri príprave stravy improvizovat', nahrádzat' kvalitné potraviny menej kvalitnými a najmä hl'adat’ d’alšie ich zdroje formou socialistických foriem samozásobitel'stva.

V období 70. - 80. rokov 20. storočia nastal nesporne pozitívny kvalitatívny obrat vo výžive obyvatel'stva Slovenska, a to najmä $\mathrm{v}$ prípade vidieckeho obyvatel'stva. Súviselo to nielen s masívnou kolektivizáciou pol’nohospodárstva a industrializáciou, ale i štátom podporovanou ideou o vyrovnávaní rozdielov medzi mestom a dedinou. $\mathrm{V}$ tom čase bola na dedinách vybudovaná väčšina obchodov s potravinami a v mestách a väčších dedinách sa začali otvárat’ 
modernejšie samoobslužné predajne. Dedinská strava sa zbavovala jednotvárneho stereotypu a začal sa menit pomer jej rastlinnej a živočíšnej zložky. S nárastom ponuky trhu narastal počet l’udí vyznávajúcich konzumné hodnoty. Všeobecne narastala spotreba mäsa, mäsových výrobkov, tuku a cukru.

Vel'ký význam pri týchto procesoch zohrávali masovokomunikačné prostriedky, najmä rozhlas a televízia. Pre ženy sa usporadúvali kurzy varenia a pečenia, vd’aka ktorým sa rozširovali nové recepty a postupy $\mathrm{v}$ príprave jedál. Používanie kuchárskych kníh a receptov z rôznych časopisov takisto prispievali k obohacovaniu kulinárnej kultúry. V domácnostiach sa čoraz častejšie presadzovali náročnejšie a nákladnejšie jedlá a snahou bolo priblížit’ sa reštauračným vzorom. To však neznamená, že sa zo stravy úplne vytratili osvedčené tradičné recepty na prípravu rýchlych, jednoduchých múčnych alebo múčno-zemiakových jedál, ktoré boli pre slovenskú kuchyňu typické.

Hodnotová orientácia l'udí sa postupne odkláňala od tradičného názoru na materiálne statky a mnohé rodiny začali manifestovat’ svoje spoločenské postavenie okrem iných prejavov aj stravou. To sa prejavilo najmä pri usporadúvaní hostín, na ktorých sa na úkor podávania tradičných jedál so symbolickým významom kvalita a kvantita stravy stávala prejavom spoločenskej prestíže. Popri tradičných krstinových, svadobných hostinách a karoch sa začali hostiny konat’ aj pri príležitostiach, ktoré sa predtým nerobili. Takto sa oslavovali maturity, promócie, výročia svadby, okrúhle narodeniny. Na druhej strane ani štyridsatročná socialistická modernizácia nevymazala zo stravy všetky tradičné prvky symbolického a náboženského významu, ktoré pretrvali najmä vo vianočnom a vel'konočnom menu.

V zmysle socialistického kolektivizmu sa postupne začalo darit’ napĺn̆at' ciel' v oblasti verejného stravovania. Štát zabezpečil dotované jedlo od jasiel' cez škôlky, školské a stredoškolské jedálne, vysokoškolské menzy až po závodné kuchyne pre pracujúcich. V oblasti reštauračného stravovania postupne narastala snaha o návrat ku 
kvalitnejšej medzinárodnej kuchyni a zároveň sa hladala originalita slovenskej kuchyne. Charakter stravy sa najmä vplyvom reštaurácií a spoločných jedální internacionalizoval.

Zdokonalenie potravinárskych technológií znamenalo obohatenie stravy o nové potraviny. Začali do nej prenikat’ konzervy, sušené, kondenzované a sterilizované potraviny. Prípravu jedál ulahčili plynové a elektrické spotrebiče na varenie a pečenie, ktoré nahradili sporáky na drevo alebo uhlie, ako aj zavedenie vody do domácností a používanie chladničiek.

Napriek nesporne pozitívnym zmenám v živote l'udí v čase budovania socializmu sa však mnohé, v nominálnom vyjadrení priaznivé ukazovatele životnej úrovne dosahovali za cenu vynakladania množstva práce a energie. Boli výsledkom vysokej miery zamestnanosti, dvojitej zamestnanosti v domácnostiach, pracovného času, ktorý bol v medzinárodnom porovnaní už výnimočným, vel'kého objemu výpomocných, brigádnických prác, ktoré sa stali nevyhnutnou a plánovanou súčastou fungovania ekonomiky, časových strát pri čakaní takmer na všetky formy predaja tovarov a poskytovania služieb alebo vel'kej časovej náročnosti dochádzky do zamestnania (Kimerlingová a kol.: 1988, 95).

Počas celej éry socializmu bolo získavanie potravín nielen otázkou väčšej či menšej miery neistoty l'udí, ale aj nástrojom politickej a sociálnej kontroly. L’udia boli na potraviny a možnosti stravovania silne fixovaní a kvalitu života porovnávali s kapitalistickými krajinami, ked' mali možnost' vycestovat', alebo s Rakúskom, ktorého televízny signál sa dal na časti územia Slovenska chytat', a ludia mohli tak prostredníctvom reklamnej ponuky na potraviny spoznávat’ aj iný spotrebný tovar. Reflektovali, že produkcia a distribúcia tovaru v socialistickom Československu nedosahovala úroveň kapitalistických krajín, napojených na globalizovaný trh. Aj výskumníci spotreby (Slater, 2004; Miller, 2005) preto hovoria, že jedným z klúčových zlyhaní, ktorý spôsobil pád socialistického režimu, boli nedostatočne uspokojované každodenné potreby l'udí, ktorí v takej spoločnosti boli nútení žit. 
Treba však objektívne povedat', že situácia v Československu bola najmä v poslednom desatročí obdobia socializmu v zásobovaní potravinami ovel’a lepšia, než napríklad v rovnakom období v Rumunsku a Pol'sku, kde potravinové obchody zívali prázdnotou. Niektoré komodity neustále na trhu chýbali, ale základné potraviny boli k dispozícii každodenne a väčšinou boli aj kvalitné. Preto l'udia z hladiska konzumácie potravín nemali vel’a dôvodov stažovat’ sa. Bola to éra v Mad’arsku príznačne nazvaná „gulášovým “, v Čechách „knedlíkovým" a na Slovensku „salámovým“ socializmom. 


\section{POUŽITÁ LITERATÚRA A PRAMENE}

Ako sme kedysi chodili k Jadranu. In: Sme. Magazín víkend, 1. VI. 2013, s. 6.

BEBEL, A.: Žena a socializmus. Bratislava 1956.

BORTEL', L.: Obchod k 40. výročiu Vel'kej októbrovej socialistickej revolúcie. In: Výživa a zdravie, 2, 1957, č. 10.

BREMZEN, V. A.: Umenie sovietskej kuchyne. Spomienky na jedlo a túženie. Bratislava 2014.

BRZÓSTOWICZ-KLAJN, M.: Rodziny i domu obraz. In: Lapiński, Z., Tomasik, W. (Eds.): Slownik realizmu socjalisticznego. Kraków 2004.

BUČKO, A.: Dnešný stav, vývoj a vyhliadky našej výživy. In: Výživa a zdravie, 1, 1956, č. 1.

BUDLOVSKÝ, J.: Stav výživy obyvatel'stva na Slovensku. Výsledky výskumu v zimnom a jarnom období 1955/1956. Bratislava : Vydavatel'stvo SAV, 1960.

BUDLOVSKÝ, J.: Niektoré pripomienky k súčasnej výživovej situácii na Slovensku. In: Výživa a zdravie, 25, 1980, č.12.

BÚRIKOVÁ, Z.: Spotreba a výskum reálne existujúceho socializmu. In: Etnologické rozpravy, 2006, č. 2, s. $81-91$.

Český lid - 1952 a nasledujúce ročníky.

DANGLOVÁ, O.: Slovenský vidiek. Bariéry a perspektívy rozvoja. Bratislava : Ústav etnológie SAV, 2006.

DRÁBIKOVÁ, E.: Záhradkárstvo ako súčasná záujmová forma tradícií polnohospodárskeho zamestnania l'udu. In: Slovenský národopis, 30, 1982, č. 3, s. 473 - 475.

DRÁBIKOVÁ, E.: Záhumienkové hospodárenie a jeho miesto v rodinnom a lokálnom spoločenstve (Na okraj zániku jednej z foriem pol'nohospodárskej malovýroby v etape rozvinutého socializmu). In: Slovenský národopis, 33, 1985, č. 2 - 3, s. $350-361$.

DRÁBIKOVÁ, E.: Socialistická pol’nohospodárska výroba a jej vplyv na spoločenské a kultúrne procesy v Sebechleboch. In: Spôsob života družstevnej dediny. Bratislava : Veda, 1986, s. $15-23$.

DVOŘÁKOVÁ-JANU゚, V .: Lidé a jídlo. Praha : ISV, 1999.

DYDA, R.: Ked' sa chodilo na obedy do Luxorky alebo socialistické vývarovne. In: Staromestské noviny, roč. 4, 2012, č. 6, s. 8.

Etnografický atlas Slovenska. (Ed.: S. Kovačevičová): Bratislava : Veda, Slovenská kartografia, 1990.

FIALOVÁ, J. A. a kol.: Medzinárodná kuchárka. Praha 1967, 1975, 1980 - Bratislava 1982.

FILOV Á, B.: Úvod. In: Banícka dedina Žakarovce. Bratislava : Vydavatel’stvo SAV, 1956. 
FRANC, M.: Ǩasy, nebo knedlíky? Postoje odborníků na výživu k inovacím a tradicím v české stravě v 50. a 60. letech 20. století. Praha 2003.

GAŽO, M.: Vajcia, zdroj cenných živín. In: Výživa a zdravie, 3, 1958, č. 5.

GOLDHAMMER, J.: Lexikon nápoju․ Merkur, 1976.

HLAVOVÁ V.: Rok 1948 - rok zlomu v agrárnej politike štátu. In: J. Pešek a kol.: Kapitolami najnovších slovenských dejín. Bratislava 2006, s. 131 - 143.

HONS, V. - ÚLEHLOVÁ-TILSCHOVÁ, M.: Správná výživa a stravování. Praha 1961.

HRUBÁ, M.: Co znamenají výrobky z mouky a obilovin pro naši výživu. In: Výživa lidu, 18, 1963, č. 11.

HRUBÁ, M.: Polotovary v naší kuchyni. In: Výživa lidu, 19, 1964, č. 8.

CHMIELEWSKA, K. - WOLOWEC. G. (Eds.): Opowiedzieć PRL.Warszawa : IBL, 2011.

JANČÍIK, V. - ZEMAN, I.: Tukový průmysl a jeho cesty ke zvýšení biologické hodnoty tuků. In: Zvyšování životní úrovně ve výživě, 1962.

JANKOVCOVÁ, L.: Referát na II. zjazde Spoločnosti pre racionálnu výživu. In: Výživa lidu, 7, 1952, č. 11.

JIRÁSEK, Z. - ŠŮLA, J.: Velká peněžní loupež v Československu 1953 aneb 50 : 1. Praha 1992.

JIRGES, M.: Verejné stravovanie na Slovensku. In: Výživa a zdravie, 1, 1956, č. 1.

KANDERT, J.: Každodenní život vesničanů středního Slovenska v šedesátých až osumdesátých letech 20. století. Praha : Nakladatelství Karolinum, 2004.

KILIÁNOVÁ, G. - POPELKOVÁ, K.: Zavádzanie marxistickej etnografie v národopise na Slovensku: zmena vedeckého myslenia? In: Slovenský národopis, 58, 2010, s. $410-424$.

KIMERLINGOVÁ, J. - KRŠÁKOVÁ, A. - KUČERÁK, J.: Životná úroveň a ekonomický rozvoj. Bratislava : VÚSRP, 1988.

KLICH-KLUCZEWSKA, B.: Przez dziurke od klucza. Źycie priwatne w Krakowie (1945 1989). Warszawa 2005.

KOCIÁN, L.: Obaly na potraviny. In: Výživa lidu, 6, 1951, č. 3 - 5.

KOTMAN, M.: Z návštevy Seredských pečivární. In: Výživa a zdravie, 1, 1956, č. 4 - 5.

KRŠEK, J.: Rolníci v dobe socializmu. Takto sme žili. Bratislava, 2010.

KRUŽLIAK, P .: Výživová politika štátu a jej ciele v socialistickej spoločnosti. In: Výživa a zdravie, 20, 1975, č. 4.

LIPTÁK, L.: Slovensko v 20. storočí. Bratislava : Kalligram, 2000.

Legendy, ktoré socializmus prežili. In: Príloha Nového času, 14. 4. 2014, s. 16 - 17.

MARCELLY, J.: Na cestu... In: Výživa a zdravie. Roč. I, 1956, č. 1.

MARKUŠ, M.: L’udová strava. In: Banícka dedina Žakarovce. Vydavatel'stvo SAV, 1956, s. $283-324$.

MARKUŠ, M.: L’udová strava na Horehroní. Kandidátska dizertačná práca NÚ SAV, 1967.

MARKUŠ, M.: Strava. In: Horehronie II. (Ed. J. Mjartan). Bratislava : Veda, 1974, s. 119 -174 .

MAŠEK, J.: Nový rok činnosti Společnosti pro racionální výživu. In: Výživa lidu, 8, 1953, č. 1.

MAŠEK, J.: Ze vzpomínek na V. I. Lenina. In: Výživa lidu, 15, 1960, č. 4. 
MILLER, D.: Consumption as the Vanguard of History: A Polemic by Way of an Indtroduction. In: Ancnowledging Consumption. A Rewiew of New Studies. London and New York : Routledge, 2005, s. $1-57$.

MJARTAN, J.: Prvý výskum l'udovej kultúry na družstevnej dedine. In: Slovenský národopis, 1953, s. $253-261$.

NESTLÉ, M.: Food politics. University of California Press, 2007.

NOVÁKOVÁ, K.: Vinohradníctvo a vinohradníci v procesoch transformácií. Trnava 2009.

O'CONNOR - HOURIHANE: The Irish national nutrition survey. In: British Journal Nutrition, 1950.

PELC, J.: Pokus o srovnání výživy v rodině zemědelské, dělnické a úřednické. In: Thomayerova sbirka přednášek a rozprav z odboru lékařského, č. 201, Praha 1940.

PETKEŠ, A.: Tradícia slovenského pohostinstva a jeho súčasná podoba. In: Výživa a zdravie, 12, 1967, č. 4.

PIOTROWSKI, G.: PRL na talerzu: Rzeczywistość kulinarna Polski ludowej. In: Nationalities Affairs, 28, 2006, s. $143-158$.

PODOLÁK, J.: K doterajším výsledkom národopisného výskumu družstevnej dediny na Slovensku. In: Slovenský národopis, 1955, s. $268-277$.

PRANDA, A.: K problematike národopisného výskumu slovenskej družstevnej dediny. In: Spôsob života družsteonej dediny. Bratislava : Veda, 1986, s. 9 - 13.

PRAŽSKÁ, L. - JINDRA, J.: Obchodní podnikání. Praha : Managment Press, 2002.

PROFANTOVÁ, Z. a kolektív: Žili sme v socializme I. Kapitoly z etnológie každodennosti. Bratislava 2012.

RADIČOVÁ, I.: Sociálny potenciál podnikavosti a prijímanie ekonomickej reformy. In: Sociológia, 25, 1993, č. $4-5$, s. $403-406$.

RAŠKOVÁ, A.: Polotovary pre domácnost'. In: Výživa a zdravie, 4, 1959, č. 7.

REMEŇ, L.: Nechajme to tak. (Dva roky života Roba Danka a jeho priatelov za éry rozvinutého socializmu, dnes nazývaného komunizmom). Uverejnené na internete, nedatované.

RYCHLÍK, J.: Pozemková reforma na Slovensku v r. 1946 - 1950. In: Historický časopis, 1993, č. 4, s. $394-413$.

SEČANSKÝ, I.: Radostné umenie kuchárske. Bratislava : Osveta, 1970.

SEČANSKÝ, I.: Kuchárska kniha pre zdravých a chorých. Bratislava : Osveta, 1978.

SCHWAER, L': Niektoré otázky spotrebitel'ského balenia potravín. In: Výživa a zdravie, 3,1958 , č. 1 .

SLATER, D.: Consumer Culture and Modernity. London : Polity, 1997.

STOLIČNÁ, R.: Súčasné tendencie v stravovaní. In: Spôsob života družstevnej dediny. Bratislava : Veda, 1986, s. $116-125$.

STOLIČNÁ, R.: Od nestrávitelného jedla k národnému symbolu. In: Etnologické rozpravy, 2002, č. 1, s. $8-27$.

STOLIČNÁ, R.: Metamorfózy jednej podhorskej dediny. In: Danglová, O. a kol.: Vidiek v procese transformácie. Bratislava 2005, s. 27 - 36.

STOLIČNÁ, R. - NOVÁKOVÁ, K.: Kulinárna kultúra regiónov Slovenska. Bratislava : Veda, 2012.

ŠEBO, J.: Zlaté 60. roky. Bratislava : Albert Marenčin - Vydavatel'stvo PT, 2008. 
ŠEBO, J.: Normálne 70. roky. Bratislava : Albert Marenčin - Vydavatel'stvo PT, 2009.

ŠEBO, J: Budovatel'ské roky 50. Bratislava : Ikar, 2010.

ŠEBO, J.: Reálne 80. roky. Bratislava : Albert Marenčin - Vydavatel'stvo PT, 2010.

ŠIŠMIŠ, M.: O súcite. Tradície a osobnosti (nielen) slovenského vegetariánstva. Martin : Slovenská národná knižnica, Národný biografický ústav, 2014.

ŠPANKO, V.: Zlepšenie výroby jedál v závodoch verejného stravovania. In: Výživa a zdravie, 2, 1957, č. $2-3$.

ŠTEFANOVIČ, M. a kol.: Rolnícke družstevné právo. Bratislava 1979.

UŠAKOVÁ, M.: L’udová strava. In: Michálek, J.: L'ud hornádskej doliny. Košice 1989, s. $85-105$.

VOROBJOV, N. J.: Program pre sbieranie materiálu na skúmanie súčasného spôsobu života kolchoznej dediny a dejín jej formovania u národností stredného Povolžia.

In: Národopisný sborník, 1952, s. 19 - 58.

www.ceskatelevize/porady/retro.

www.pravda.sk / co bolo ked neboli hamburgery.

ZAJONC, J.: Pri stole pracujúcich alebo tekvica ako ananás. In: Etnologické rozpravy, 2006, č. 2, s. $188-204$.

ZÁPOTOCKÝ, V.: Ke struktuře spotřeby masa. Spotřeba potravin v ČSSR a ve světě. In: Výživa lidu 19, 1964, č. 2.

ZÁPOTOCKÝ, V.: Spotřeba obilovin u nás a ve světě. In: Výživa lidu, 20, 1965, č. 4.

ZATKALÍKOVÁ, A.: Rast životnej úrovne dedinského obyvatel'stva a zmeny v jeho spôsobe života. In: Současná vesnice. (Ed.: V. Frolec). Brno : Blok, 1977, s. 197 - 204. 


\section{SUMMARY}

The study of human nutrition allows to analyse social changes. Since people need to eat, different events, processes and changes can best be grasped through food and related practices and experiences from everyday life. Food changes abstract political concepts to personal, very concrete reflections of social changes, which also applies to the topic analysed herein: practices and changes in public nutrition in Slovakia during the period of constructing socialism.

The political authoritarian regime under the leadership of the Communist Party of Czechoslovakia (CPC), established in our country in 1948, was massively involved in an entire complex of functions and norms of the society. Mainly during its first stage, in the 1950s when its ideological fundaments and essence were formed, in addition to its primary aim to win and consolidate its power it also had the vision of creating "new" socialist people behaving and living in line with the established political line. The "new" man was one of the central figures of the socialist era in general. Their newness was in sharp contrast with tradition, but the very idea of the new model of humanity was based on the European tradition of modernity. This model promoted the independence of individuals from family and the representation of family ties by other types of collective feelings of belonging, and reflected the symptoms of general civilisation changes, such as technical progress, urbanisation, mass migration, women's emancipation, and the general cultural emancipation of the society. The Communist propaganda often referred to these phenomena and adopted them to its ideological demands. It was characteristic for this regime that it sought to form "new" people by influencing all parts of their lives, including the most intimate ones. One of the aims was to transform the "backward" rural population 
into a modern conscious class. This process resulted in the fact that most every-day situations ceased to have an individual nature and became society-wide issues. This concerned housing, clothing, education, culture, religion, sports, and, naturally, eating.

With regard to production, modernisation in the socialist perception primarily focused on the development of the heavy industry and on infrastructure construction. As a result of the nationalisation of the means of production, farmers and workers did not produce for their own consumption, but sold their labour force to the state for money in the form of salary. The fact that the means of production were owned by the state and not by the people, who used them, shifted their relationship to material culture towards consumption. Since collectivisation and nationalisation which took place during the first stage from 1948 to 1954 and during the second stage from 1955 to 1960, as well as during the period of nationalisation of industry started in 1945 and completed in 1948, most material items became the object of a consumer relationship, and not of a production one. Socialism thus completed the consumption revolution in Slovakia. These changes in consumption were presented as gradual modernisation of society and as the success of the Communist ideology. The level of consumption - its affluence or shortage - also formed people's relationship towards the socialist regime. On one hand, increased consumption and the satisfying of people's basic needs served the Communist Party to legitimise its power; on the other hand, the shortage of goods (especially basic foodstuffs) was reflected in their critical evaluation of the socialist reality.

In 1948, the leadership of the Communist Party of Czechoslovakia set out the directions and tasks of the agricultural and nutrition policy. These were closely linked to the collectivisation of agriculture, the building of farmers' cooperatives, and the paternalist administrative and directive management of economy and society. The centralised production planning through the Ministry of Agriculture, the State Planning Authority, and agricultural offices at re- 
gional, district and local levels were expected to restrict or eliminate the "decision-making of capitalists and small producers". However, a large part of farmers did not welcome the nationalisation of agricultural production with enthusiasm. Local authorities sought to force those hesitating to enter a cooperative by means of material support and promises, but also under various kinds of pressure, benefits scheduling, strict exaction of unfulfilled tasks, high taxes, firing of relatives from employment or schools, or by calling "kulaks" to army work units.

Even though the Communist propaganda was keen on accentuating the building successes of the nationalised industry and state agricultural cooperatives, the economic production sector failed to ensure sufficient supplies of products and foodstuffs to the population on the free market. As a result of this situation, the Communist regime was forced to introduce a food rationing system in the period from 01 January 1950 till 31 May 1953. Under this system, food rations were limited and allocated according to people's age and occupation. The groups privileged by the regime, such as miners, metallurgists, the police, and Communist cadres, could benefit from increased rations on the controlled market, in which they could purchase products in exchange for coupons.

Some categories of people were excluded from the rationing system, such as senior officials, police and army officers from the prewar Czechoslovak Republic, trade licence holders, traders, etc. They could only purchase products on the free market for prices several times higher. Also smaller farmers who failed to meet mandatory supplies of meat, milk and eggs did not get coupons for sugar and other products. Members of poor-performing agricultural cooperatives that failed to ensure the set amounts of food supplies to the public sector were in a similar situation. Moreover, a decree of the Ministry of Internal Trade defined a group of self-suppliers - owners of lands of over 0.5 ha - who were not entitled to food coupons. The rationing coupon system was cancelled one day before the money exchange, under which people could exchange their for- 
mer money of up to 300 Czechoslovak crowns at the rate of 5:1, and higher amounts and deposits at the rate of 50:1.

The death of J. V. Stalin in 1953 meant a turn towards greater interest in people's living standards in the entire Soviet bloc. The professional discourse on nutrition was similar to the one on other areas of life. It highlighted not only the big importance of nutrition for society, but also its health impacts and, secondarily, its economic aspects as a means to increase the productivity of people's work. In the 1950s, the progress in food quality was constantly accentuated as compared to the interwar period.

A general feature of contemporary expert nutrition studies was the faith that the new people's democratic and later socialist society would bring a new life-style also in the field of nutrition by respecting the health needs of people without the desire of food producers to earn profits... Nutrition manifested most clearly the class character of the old capitalist society, while the socialist system enables full respect for biological aspects. Food ceases to be the subject of profit and becomes the means for a new socialist man to be healthy and fully efficient... This is a quote from the resolution adopted at the working conference of the Association for Proper Nutrition in 1950. For most experts, especially for physicians, this meant that they could influence people's eating habits to an extent which was previously unthinkable. The vision of a society managed by scientists was a synonym for socialism for many nutritionists.

From the mid-1950s, Czechoslovakia launched a campaign in line with the changes in its nutrition policy, emphasising the benefits of new technologies and the need for a total transformation of people's eating habits. It was related to contemporary modernist ideas associated with the promotion of scientific knowledge in everyday life. The symbols testifying the importance of technical and biological sciences in the field of nutrition included, in particular, various kinds of processed food, especially intermediate products and different ways of food preservation. The professional and promotional materials constantly stressed that people's distrust in such 
food does not have actual justification; on the contrary, processed foodstuffs bring significant time savings. The growth of intermediate food products was also related to the process of "liberation" of working socialist women from housework and with the development of common catering in schools, factories, offices, etc. It was envisaged to centralise production to a maximum extent possible, and to establish an intermediate product industry as a separate food industry sector. Despite all proclaimed benefits, the popularity of intermediate food products was not as their proponents had imagined. The reason behind, according to contemporary experts, was the ignorance of the economic importance of time while preparing meals at home. Greater dissemination of intermediate products in the countryside was prevented by the problem related to their distribution, storage, prices, and traditional eating habits.

The technical and technological development in the field of nutrition was also accompanied by a planned shift to automated, continuous food production with high production hygiene as one of the expected positive results. The issue of appropriate food packages, especially for meat, fat and milk, was of special interest.

Besides technological problems, the situation was complicated by the fact that compared to more developed countries the purchase of food constituted a significant burden to Czechoslovak citizens. Economists explained this situation by the fact that other living costs, such as the costs of housing, healthcare, culture and taxes, were lower compared to capitalist countries. The high proportion of food costs, however, led to a situation where most households considered proper and healthy nutrition which was extremely expensive a luxury. People mostly criticised the high prices of meat, exotic fruit and butter. Nutritionists therefore sought to manipulate the public opinion in order to improve the conditions of public nutrition. They promoted cost advantageous foodstuffs with the aim to increase their consumption. For example, in times of insufficient consumption of milk and milk products or eggs, they stressed the low prices of this rich source of animal proteins. One of the leit- 
motifs of promoting a healthy diet, in addition to variety, was the need for moderation due to enormous increase in fat and sugar consumption, mainly as a result of the food coupon system. The public consumption system offered another possibility for food price manipulation and constituted one of the priority efforts of those advocating proper nutrition in the 1950s. Public catering was to become the main source of positively influencing the eating habits of the general public. In spite of the awareness raising efforts, the majority of the population continued to maintain the traditional concept of "good" food, which was acknowledged by nutrition researchers.

In the mid-1950s, public nutrition was studied by researchers from the People's Nutrition Institute in Bratislava. The results obtained from the research led by MUDr. Juraj Budlovský in 1955/1956 offer a large amount of data documenting the socialist reality in the field of nutrition. The part analysing the contents of meals in examined families represents a relevant source of information. The following facts summarise the findings:

In the countryside, certain, mainly typical regional dishes were served several times a week or even constantly throughout the week, except Sunday. This eating stereotype constituted the main difference between towns and the countryside, and was present all over Slovakia. People in towns ate less, yet more frequently; the meals were more varied and balanced, and greater attention was paid to regularity and food preparation. The biggest problem of nutrition in the countryside, especially in the mountainous northern regions, was a limited number of basic foodstuffs: cereals, potatoes, sauerkraut, and milk, i.e. foodstuffs (other than milk) containing carbohydrates which, with the low consumption of meat and eggs, had small protein content. The meals were therefore rather unbalanced in terms of nutrients. These results are very similar to those obtained in Czechoslovakia during the economic crisis in the 1930s. This means that not even after seven years of the building of socialism could one witness a positive turn in the quality of nutrition of the rural population. 
Relevant information on the given period can be found in the part of the book by J. Budlovský which analyses the economic factors of public nutrition, especially those related the distribution of foodstuffs. This part of the book presents a number of important facts, in particular researchers' statements on food production and distribution that had a substantial impact on the quality and balance of public nutrition. In the mid-1950s, it was mainly the lack of distribution of some basic foodstuffs in Slovakia: cream, curd, fresh meat, fruits, and vegetables. The production and distribution sectors were even unable to ensure nutrition for babies in the form of milk powder. Another problem was the imbalanced distribution between urban and rural areas; some basic foodstuffs (bread, for example) were not distributed to rural grocery stores at all, or only sporadically. In addition to insufficient and often inadequate food supplies, another factor also influenced the eating habits in the countryside - the poor network of grocery stores. Another negative factor was the seasonal character of foodstuffs, due to which contemporary distribution was not able to satisfy people's needs, i.e. to ensure enough fish during fasting periods, or enough butter, curd, eggs, meat, and fruit during festive days, etc. On the other hand, sugar consumption largely increased, which was considered a positive result, but from the point of view of proper and healthy nutrition it was rather seen as a negative condition with long-term health effects on the Slovak population. It is apparent that the research in public nutrition in 1955/1956 did not bring very optimistic results, but rather the opposite.

The Communist ideology claimed that food production and distribution in the socialist political system depends on and is governed by the needs of broad masses of people. The centralised planned system of management failed to meet these claims, which caused, in the network of grocery stores, the lack of an appropriate range of food products in terms of quantity or quality for all population groups. Some food products were scarce, and this concerned both domestic production and imported foodstuffs. 
With insufficient food supplies, people were forced to seek other sources and to ensure food mainly through self-supplies. Self-supplies of food during the period of socialism, however, cannot be understood in the same way as in the previous historic periods, when the economy supplied families with all necessary food items. In the socialist period, it was rather about home making of food products, or food received as gift or by exchange, thus supplementing or replacing purchased foodstuffs.

In the period of socialism, this type of enterprise was needed to plug the gaps caused by shortages in the formal economy. Food production in families was commonly performed along with other jobs, giving rise to three basic types of families in the proclaimed homogenised socialist society - depending on existence or absence of home production: self-supplier family; entrepreneur family; and user family. Their common feature was the fact that family members were employed in the state sector. According to the research conducted in 1984, up to $70 \%$ of the population developed household economy, and one tenth of them sold their products. The ownership of a garden or land was an important economic factor in Slovakia and a "social safeguard" under the socialist economic conditions. Double employment was one of the most important strategies of solving the personal situation of people.

In villages, it was a specific link between traditions, social relationships and pressures, as rural people were always strongly integrated into the network of social ties (between relatives, neighbours, communities, etc.) and extensive links of mutual reciprocal dependence. Different positions, chances and appraisals were obtained in the rural society by means of certain conformity: exchange of work and payment in kind, gifts or services in return as a product of long-term reciprocity processes. Hence, "socialist" self-supply was an engaged activity of people, including a whole range of other meanings and mechanisms, such as: home-made food products as the family's economic safeguard; safety of home-made food products; people's ties to land, social control of villages and prestige of 
family, absence of grocery stores and of shopping opportunities, as well as relax in nature, elements of entertainment, self-realisation, and joy from attained food production. The provision for food in the socialist period was a kind of "small private happiness", considered by many people, not only from the countryside, the most important thing in their lives, restricted to a small social space and its embellishment. Works in the garden or in the field were considered a model of "meaningful" life. Back in the mid-1980s, mainly older villagers considered the self-supply of food a fundamental life necessity satisfied mainly in the interest of their children and grandchildren who often lived in towns and cities. Home-made food products represented a contribution to improving the standard of their alimentation, and the money acquired from sale was used to invest in the building of a house, or in the purchase of a flat or of a car.

Since the 1970s, part of the urban population of Slovakia started to search for possibilities of weekend housing in the countryside, having purchased older rural houses, usually with gardens and orchards. In this way, they were able to produce food on their own, mostly vegetables and fruits, thus supplementing their meals. At the same time, they established contacts with the local rural inhabitants who offered them their food products for sale.

During the socialist period, garden colonies were created and expanded in city outskirts, using lands, in the exploitation of which the state had no interest. People thus cultivated the neglected or unsuitable land areas. The demand for such lands was enormous, as a result of which they were allocated mainly to the deserving (people of worth to the socialist society). The garden colonies created new social ties based on the same interest - producing of fruits and vegetables for own consumption or for sale on the market. People exchanged their experiences, organised social events - exhibitions of their crops, evening parties, and were also involved in the " $\mathrm{Z}$ activity", which was a socialist competition of improving their surroundings. 
In 1989, the number of gardeners who could sell their surplus crops to wholesale centres or on markets reached more than 400,000. In addition to gardens next to private houses, gardening was another important element that helped supplying the population with fresh fruits and vegetables.

In the Slovak countryside and in smaller agrarian towns, selfsupply was the principal way of ensuring the widest possible range of foodstuffs during a long historic period before the socialist era. Their variety got reduced during the period of socialism, and the range of meals prepared from home-made food at home changed, too. One of the typical examples was the cessation of home production of bread, butter, oil, etc. On the other hand, new contemporary knowledge, used in industry, was started to be used in home processing of food. One such example is slaughtering processes and products. In addition to traditional ways of meat preservation - by salt and smoke, households also used new preservation techniques, such as the use of curing salt, or sterilisation in glasses or tin cans. The popularity of home-made sausages and the possibility to buy meat casings and meat beyond the quantities obtained in home slaughters led to the fact that their production was not always connected with slaughter, and sausages started to be produced also by people living in urban areas. The range of home-made products also included ham, which was produced using similar methods as those applied in industry, mostly by means of home-made devices.

Home-made food products were highly appreciated during the socialist period, and, in general, were considered higher quality than those offered in groceries. People therefore sought different opportunities to obtain such foodstuffs.

Another possibility for people in the socialist system of getting quality food (and other) products from abroad or products aimed for export was shopping in TUZEX foreign trade enterprise stores. Products from these shops could be purchased for vouchers (bony) obtained in exchange for foreign currency, such as US or Canadian dollars, German marks, or Swiss or French francs. These 
luxury goods were accessible by people who had the possibility to get foreign exchange through their relatives living abroad or from pension for work abroad. People without such possibilities obtained vouchers illegally from dealers in the street right in front of TUZEX stores. Endless crowds of people stood in front of these stores mainly before holidays, wishing to buy scarce food products: alcoholic drinks, quality chocolate, Dutch cacao, instant coffee, Ovomaltine, Heinz ketchups, Wrigley's chewing-gums, etc. The category of the Communist party and state elite could also purchase relatively cheap luxury food products in well-supplied diplomatic shops, paying with Czechoslovak crowns. People who could shop in TUZEX stores or diplomatic shops were perceived by the general population as a privileged group with a higher material and social capital.

Quite a curiosity of socialist eating habits was the trips of Czechoslovak citizens abroad, especially to Yugoslavia since 1960s. Even though this country formed part of the socialist block, it had a touch of capitalism, and it was relatively easy to get to Austria or Italy from there. It was the dream of many people to spend their holiday at the seaside in Yugoslavia in spite of the fact that they had to undergo administrative torture to be able to travel. Unless they travelled through a travel agency, they had to ask the Czechoslovak State Bank in the beginning of the year for a foreign exchange pledge with a letter of recommendation from the employer. The bank then decided whether it would sell the requested foreign exchange - Yugoslav dinars in this case - to the respective individuals. But this is not all. They were required to submit the foreign exchange pledge and the application for departure to the Ministry of Interior to receive a departure document, on the basis of which they could travel. The foreign exchange pledge was usually very low, and it was impossible to exchange Czechoslovak crowns in Yugoslavia. Those who were lucky to travel to Yugoslavia on an individual basis by car were carrying food with them to campsites and were cooking on portable propane-butane cookers. And since they usually went 
for a three-week holiday, it was necessary to preserve the food for as long as possible.

In spite of sincere efforts of mainly scientists to ensure availability, nutrition balance, variety, health and safety of foodstuffs, the reality of socialist food production and distribution in the 1950s did not reach the quality claimed by the regime. The acquisition of basic foodstuffs was associated, especially during the first two decades of this period, with feelings of discomfort in people - due to the lack of foodstuffs and their poor quality, loss of time related to food acquirement, and high prices in some cases. Naturally, these facts had a negative impact on the nutrition models of people, as families were often forced to improvise in the preparation of meals, to replace foodstuffs with those of lower quality, or often eat the same meals throughout the week.

These conditions gradually improved during the 1970s and 1980s. Unlike in Romania and Poland, where food stores were virtually empty, people in Czechoslovakia did not really have many reasons for protests in terms of consumption. It was an era of full plates, called "goulash" socialism in Hungary, "dumpling and pork" socialism in the Czech Republic, or "sausage" socialism in Slovakia. Nobody starved whatever the quality of meals was. However, food production and distribution in the socialist Czechoslovakia never attained the level of developed capitalist countries connected to the globalised market. Consumption researchers therefore note that one of the key failures causing the fall of the socialist regime was the failure to satisfy people's everyday needs. 



\section{RASTISLAVA STOLIČNÁ-MIKOLAJOVÁ}

\section{Socializmus na tanieri}

\section{Možnosti a praktiky stravovania obyvatel'ov Slovenska v rokoch 1948 - 1989}

Návrh obálky: Mgr. Marek Petržalka

Zodpovedný redaktor: Emil Borčin

Technická redaktorka: Jana Janíková

Prvé vydanie.

Vydala a vytlačila VEDA, vydavatel'stvo Slovenskej akadémie vied, v Bratislave roku 2015 ako svoju 4 151. publikáciu. Strán 160.

www.veda-sav.sk 
Človek potrebuje jest' každodenne a v každej dobe.

Konzumované potraviny a spôsoby stravovania l'udí sú preto dobrým indikátorom procesov a zmien v sociálnych spoločenstvách. Kniha etnologičky Rastislavy Stoličnej-Mikolajovej prezentuje najvýraznejšie zmeny, ktoré nastali v oblasti výživy a stravovacích modeloch l'udí počas epochy budovania socializmu na Slovensku. Objasňuje kontexty ingerencií štátnej komunistickej ideológie, ktoré spôsobili zásadnú ruptúru v produkěno-zásobovatel’ských princípoch v stravovaní obyvatel'stva. Z novej politickej a hospodárskej situácie vyplynula aj nová koncepcia výživy socialistického človeka, ktorá sa inšpirovala najmä sovietskym modelom a bola aplikovaná v stravovaní l’udí v masovom meradle počas celého obdobia socializmu. Hospodárske, spoločenské a politické udalosti zasahujúce slovenské spoločenstvo sa menili u l'udí na vel'mi konkrétne, osobné reflexie týchto zmien. Prejavilo sa to v postupných zmenách foriem stravovania v rodinách aj mimo nich i v skladbe produkovaných a konzumovaných potravín, čo viedlo k významnej premene výživových modelov obyvatel'ov Slovenska.

ISBN $978-80-224-1467-8$

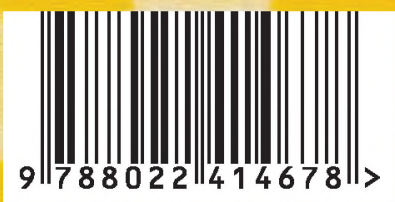

